\title{
A Estatística na Escola Básica Uma Prática de Inferência Informal
}

Apolo Rubens de Camargo

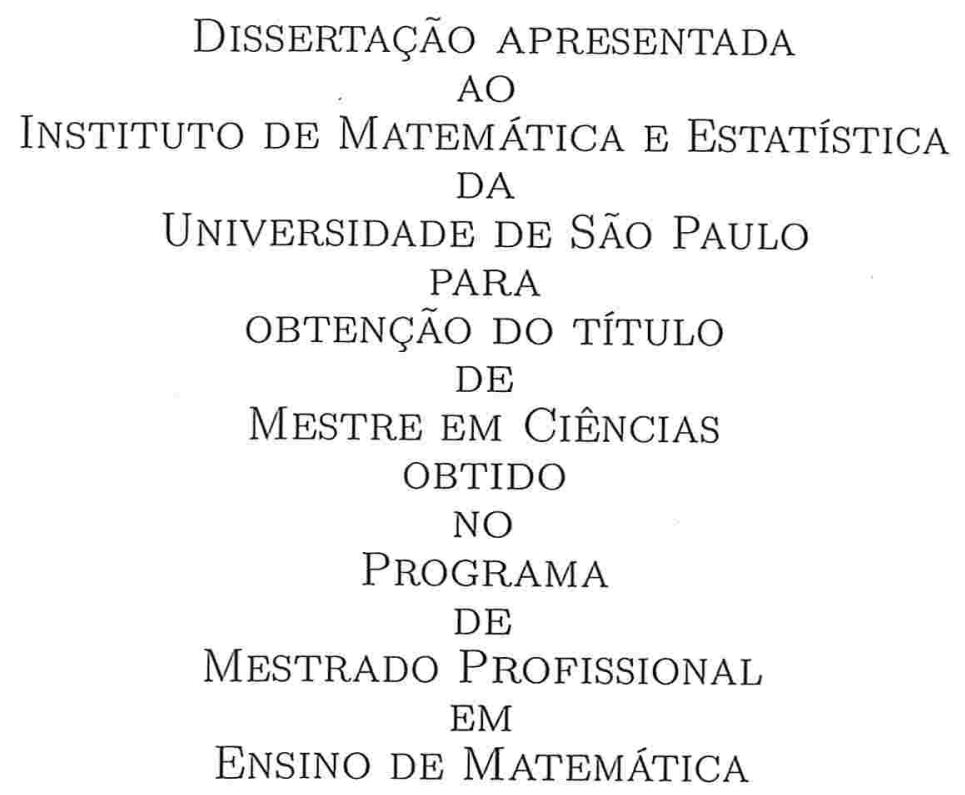

Programa: Mestrado Profissional em Ensino de Matemática Orientadora: Profa. Dra. Lisbeth Kaiserlian Cordani 


\title{
A Estatística na Escola Básica Uma Prática de Inferência Informal
}

\author{
Apolo Rubens de Camargo
}

Esta versão dissertação contém as correções e alterações sugeridas pela Comissão Julgadora durante a defesa realizada em 02/06/2016 e substitui o original depositado inicialmente no Instituto de Matemática e Estatística da Universidade de São Paulo.

Comissão Julgadora:

- Profa. Dra. Lisbeth Kaiserlian Cordani (orientadora) - IME USP

- Prof. Dr. Marcos Nascimento Magalhães - IME USP

- Profa. Dra. Cileda de Queiroz e Silva Coutinho - PUC SP 


\section{Agradecimentos}

A Deus por minha vida, família e amigos. Aos meus pais, pelo amor e apoio incondicional. À minha orientadora Lisbeth Kaiserlian Cordani, pelas suas correções e incentivos. Aos demais professores que desde os primeiros anos de minha vida escolar transmitiram preciosas lições. A todos que direta ou indiretamente fizeram parte de minha formação, meus eternos agradecimentos. 


\section{Resumo / Abstract}

Este trabalho se inclina principalmente para a relação professor-aluno, mais especificamente sobre a prática docente em sala de aula no que se relaciona aos primeiros contatos dos alunos com as concepções fundamentais da Estatística. Além da apresentação de alguns conceitos elementares de Estatística, foram colocadas as ideias de alguns autores sobre a Educação Estatística, necessidades e dificuldades. Em seguida, foi apresentado o raciocínio associado à Inferência Estatística Formal (no sentido clássico) e suas dificuldades teóricas. Como exemplo norteador para prática docente foi desenvolvida e comparada uma análise inferencial sob dois pontos de vista: a Inferência Formal e a Inferência Informal, sendo esta última uma área emergente da Educação Estatística. Dessa comparação foram destacados alguns aspectos da Inferência Formal que dificultam o entendimento dos principais conceitos básicos da Estatística e, diante disso, sugerida uma abordagem alternativa menos rigorosa e direcionada a evitar ou diminuir os erros conceituais mais comuns relacionados ao assunto, a chamada Inferência Informal.

Palavras-chave: Educação Estatística, Inferência Informal, Conceitos Estatísticos.

This work refers mainly to the teacher-student relation, more specifically to the teaching practice in the classroom as it relates to students? first contact with the fundamental concepts of Statistics. Beyond the presentation of some elementary concepts of Statistics, some authors? ideas on Education Statistics, needs and difficulties were also placed. Then the reasoning associated to the Formal Statistics Inference was presented (in the classical sense) and its theoretical difficulties. As an example for guiding teaching practice, an inferential analysis from two points of view was developed and compared: the Formal Inference and the Informal Inference, being the last one an emerging area of Statistics Education. From this comparison some aspects of Inference Formal were highlighted, which hinder the understanding of the main basic concepts of Statistics and, due to that, a less restrictive alternative approach was suggested aiming to prevent or reduce the most common misconceptions related to the subject, this is called Informal Inference.

Keywords: Statistics Education, Informal Inference, Statistical Concepts. 


\section{Sumário}

Lista de Figuras vii

Lista de Tabelas $\quad$ ix

1 Introdução 1

2 A Estatística e Alguns Conceitos 3

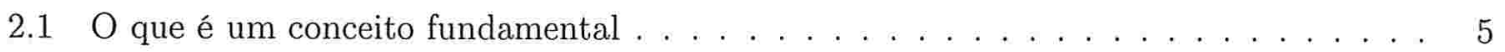

2.2 Erros Conceituais . . . . . . . . . . . . . . . . . . . . 6

2.3 Algumas Ideias Fundamentais da Estatística . . . . . . . . . . . . . . . . . . . . 8

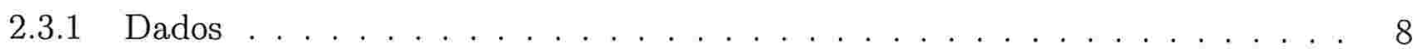

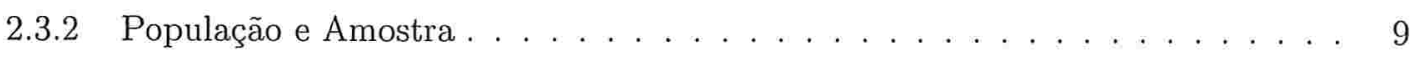

2.3 .3 Medidas Descritivas . . . . . . . . . . . . . . . . . . . . 13

2.3 .4 Recursos Gráficos . . . . . . . . . . . . . . . . . . . . . . . 22

3 Educação Estatística $\quad 27$

3.1 Crescimento do Interesse e da Necessidade da Estatística . . . . . . . . . . . . . . 28

3.2 Necessidades Estatísticas de um Cidadão . . . . . . . . . . . . . . . . . . . . 29

3.3 Diferenças e Semelhanças entre Matemática e Estatística . . . . . . . . . . . . . . . . 30

3.4 Tratamento da Informação e Análise Exploratória de Dados . . . . . . . . . . . . . 31

3.5 Componentes da Educação Estatística . . . . . . . . . . . . . . . . . . 31

4 Educação Estatística - Algumas Dificuldades 35

4.1 Atuação do Professor . . . . . . . . . . . . . . . . . . . . . . . . . 35

4.2 Excesso de Matemática e Mecanização de Procedimentos . . . . . . . . . . . . . 36

4.3 Abstração e Linguagem . . . . . . . . . . . . . . . . . . . . . . . . . . . 37

5 Inferência Estatística $\quad 39$

5.1 Inferência Informal . . . . . . . . . . . . . . . . . . . . . 41

5.2 Inferência Formal . . . . . . . . . . . . . . . . . . . . . . . . . . 42

5.2 .1 Os Testes de Hipóteses e o Raciocínio Lógico . . . . . . . . . . . . . . . . . 43

5.2.2 Os Testes de Hipóteses e Outros Procedimentos Associados . . . . . . . . . . 45

5.2.3 Dificuldades da Abordagem Formal na Escola Básica . . . . . . . . . . . . . 46

5.3 Distribuição Amostral . . . . . . . . . . . . . . . . . . . . . . 46

5.4 Teste de Hipóteses $\ldots \ldots \ldots$. . . . . . . . . . . . . . . . . . . . . . . . . . . . . . 47 
6 Comparação Entre Dois Grupos 49

6.1 Explorando a Comparação Entre Dois Grupos . . . . . . . . . . . . . . . . . . 50

6.2 Comparação Entre Dois Grupos - Uso de Inferência Formal . . . . . . . . . . . . . 51

6.2.1 Principais Dificuldades Relacionadas à Abordagem Formal . . . . . . . . . . . 58

6.3 Comparação Entre Dois Grupos - Uso de Inferência Informal . . . . . . . . . . . . 59

6.4 Ainda sobre Inferência Informal $\ldots \ldots \ldots \ldots \ldots \ldots \ldots$

7 Considerações Finais $\quad 73$

$\begin{array}{ll}\text { Referências Bibliográficas } & 77\end{array}$ 


\section{Lista de Figuras}

2.1 População e Amostra . . . . . . . . . . . . . . . . . . . . . . . . 10

2.2 Exemplo de Fila Ordenada . . . . . . . . . . . . . . . . . . . . . 15

2.3 Gráfico de Pontos . . . . . . . . . . . . . . . . . . . . . 23

2.4 Estrutura de um Box Plot (Gráfico de Caixas) . . . . . . . . . . . . . . 26

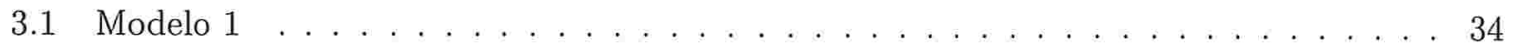

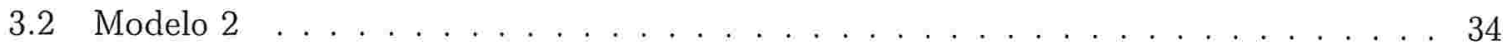

6.1 Curva Normal e Valor Observado . . . . . . . . . . . . . . . . . . . . . 56

6.2 Curva Normal e Valor Observado . . . . . . . . . . . . . . . . . . . . . . 56

6.3 Probabilidade Associada ao Valor Observado . . . . . . . . . . . . . . . 57

6.4 Gráfico de Pontos . . . . . . . . . . . . . . . . . . . . . . . 65

6.5 Gráfico de Caixas (Box Plot) com Gráfico de Pontos Sobreposto . . . . . . . . . . . 67 
viii LISTA DE FIGURAS 


\section{Lista de Tabelas}

2.1 Remuneração hora/aula . . . . . . . . . . . . . . . . . . . . . . 18

2.2 Medidas de posição . . . . . . . . . . . . . . . . . . . . . . . . . 19

2.3 Uma medida de variabilidade . . . . . . . . . . . . . . . . . . . 20

2.4 Tabela completa . . . . . . . . . . . . . . . . . . . . 21

6.1 Notas finais dos alunos . . . . . . . . . . . . . . . . . . . . . . . 55

6.2 Notas finais dos alunos . . . . . . . . . . . . . . . . . . . 60

6.3 Medidas Resumo . . . . . . . . . . . . . . . . . . . . 68 


\section{Capítulo 1}

\section{Introdução}

Este estudo busca analisar algumas situações ligadas à Educação Estatística, entre elas aspectos curriculares, algumas práticas atuais, alternativas de abordagem, e algumas práticas desaconselhadas. Serão destacadas características educacionais bem como conceitos básicos relacionados à Estatística. Também pretende discutir alguns aspectos de um campo de estudo emergente dentro da Educação Estatística, a Inferência Informal, que vem se mostrando como alternativa para a disseminação inicial dos conceitos fundamentais da Inferência Estatística, que geralmente são abordados de forma mecanizada para os iniciantes no tema.

De acordo com Ben Zvi e Garfield (2004), os métodos tradicionais do ensino de Estatística enfatizam técnicas algorítmicas e, como consequência, não promovem o entendimento nem o desenvolvimento das habilidades de relacionar os conceitos básicos. Dessa maneira acabam formando alunos que, apesar de calcular medidas e de aplicar os métodos estatísticos, não conseguem interpretar os resultados obtidos. Uma das necessidades diante desse tipo de prática, encarada como um desafio pelos mesmos autores, é a mudança de foco para abordagens que auxiliem os alunos a compreenderem e relacionarem as ideias estatísticas básicas.

Diante desse cenário educacional, pesquisas estão sendo desenvolvidas para melhorar essa situação, oferecendo uma variedade de maneiras de ensinar, ajustadas às particularidades das classes, em todos os níveis de escolaridade. Como alternativa para melhoria das práticas tradicionais comuns nas salas de aula muitos profissionais que ensinam Estatística estão substituindo esse tipo de abordagem por uma outra chamada de Inferência Informal. Esta abordagem não é só baseada nas técnicas tradicionais pois busca o desenvolvimento dos conceitos e das habilidades que tornam as pessoas capazes de organizar, interpretar, representar e inferir de forma coerente utilizando dados estatísticos.

Por meio da Inferência Informal também é possível que os alunos relacionem os dados à informações adicionais trazidas de sua experiência própria aproximando o conhecimento acadêmico à sua vida cotidiana. Atualmente, de certa forma, a ninguém é "permitido dispensar o conhecimento da Estatística sem abdicar algumas coisas, entre elas a consciência sobre suas ações."Brasil (1997)

Ainda de acordo com Ben Zvi e Garfield (2004), um dos maiores obstáculos para proporcionar uma melhoria na maneira de ensinar Estatística é a falta de experiência e de instrução dos professores desenvolverem um ensino de estatística que construa os conceitos fundamentais à partir da análise de dados. Assim, os profissionais ligados à Inferência Informal estão se empenhando para tornar os resultados observados mais acessíveis aos professores, principalmente os professores que ensinam Estatística aos alunos iniciantes que nunca tiveram contato com o tema. 
Considerando o momento atual pelo qual a Educação Estatística esta passando e o empenho dos profissionais ligados a essa área, este trabalho tem o objetivo de:

- Identificar os desafios (obstáculos) enfrentados pelos professores durante o processo de ensino e aprendizagem;

- Identificar as dificuldades relacionadas ao ensino da Inferência Formal no nível básico;

- Elencar os principais conceitos elementares da Estatística;

- Comparar o uso da Inferência Formal e Informal na resolução de um problema;

- Desenvolver um exemplo que possa auxiliar os professores do ensino básico e superior a introduzirem, desenvolverem e articularem conceitos e ideias por meio da Inferência Informal.

De acordo com Fiorentini e Lorenzato (2006) e com os objetivos listados acima, este trabalho poderia estar ligado ao estado da arte da Inferência Informal uma vez que envolve algumas necessidades relacionadas ao campo da Educação Estatística, tanto de natureza pragmática (melhorias no ensino e no aprendizado) quanto de cunho científico (produção de conhecimento). Pesquisas desse gênero trazem, de certo modo, um resumo sobre um tema e por isso uma realidade menos abrangente daquela trazida diretamente pelas obras consultadas e que a originaram. Uma outra forma de caracterizar este trabalho seria classificá-lo como uma pesquisa de natureza qualitativa. 


\section{Capítulo 2}

\section{A Estatística e Alguns Conceitos}

A origem da Estatística, conforme relata Batanero (2001), se deu na Antiguidade, por volta de 1000 anos a.C., onde se situam registros entre os povos chinês, sumério e também egípcio. Até mesmo na Bíblia, no livro de Números, encontram-se registros de natureza Estatística nos quais se destaca o povo Romano, que no século IV a.C. utilizou esse tipo de conhecimento para realizar censos populacionais.

Mesmo assim, somente recentemente a Estatística foi reconhecida como uma ferramenta importante para tomada de decisão em diversas áreas do conhecimento e alguns autores, como Batanero (2001), por exemplo, descrevem-na como uma ciência.

De acordo com Hand (2008), não existe uma definição perfeita para Estatística, mas vejamos algumas definições para ele, organizadas cronologicamente, a partir de 1974:

"(...) uso dos números para representar propriedades. "Campbell (1974)

"A Estatística é o instrumento lógico, fundado no método indutivo, que tem por objetivo a descoberta em forma e valor das leis dos fenômenos coletivos e de multidão, quaisquer que sejam os campos experimentais a que eles pertençam." Almodova (1978)

"É a disciplina que orienta como descrever e explicar como as coisas variam." Chalmer (1987)

"(...) a Estatística é a ciência de coletar e analisar dados." Rees (1995)

"A Estatística está interessada nos métodos científicos para coleta, organização, resumo, apresentação e análise exploratória de dados, bem como na obtenção de conclusões válidas e na tomada de decisões razoáveis baseadas em tais análises." Spiegel (2006)

"A Estatística é a ciência da obtenção de informações a partir de dados numéricos. (...) fornece instrumentos e ideias para utilizar dados com o objetivo de compreender algum outro assunto." Moore (2000)

"(...) é a tecnologia para extrair significado dos dados. (...) é a disciplina chave para conjecturar o futuro ou para fazer inferências sobre o desconhecido ou para produzir sumários convenientes de dados." Hand (2008)

"Um conjunto de técnicas que permite de forma sistemática organizar, descrever, analisar e interpretar dados oriundos de estudos ou experimentos realizados em qualquer área do conhecimento." Magalhães e Lima (2011)

Em São Paulo (2011) podemos encontrar algumas orientações sobre o ensino que atendem alguns aspectos das definições anteriores. Nos quadros de conteúdo de habilidades de Matemática, desde o $6^{\circ}$ ano até as séries finais encontramos tópicos relacionados com a compreensão da Estatística e com a Análise e Exploração de Dados. Nesse documento consta que é preciso preparar o aluno para 
um ambiente fora da escola onde a articulação com o mundo externo à escola exige pessoas cada vez mais capacitadas e aptas a selecionar, organizar, relacionar, interpretar dados e informações representados de diferentes formas, para tomar decisões e enfrentar situações diversas.

Embora essas orientações estejam na seção de Matemática, percebe-se que as orientações descritas apresentam uma forte relação com as definições de Estatística apresentadas. Diante da estrutura educacional e curricular vigentes, encontramos professores de Matemática lecionando Estatística, pois o conteúdo de Estatística é distribuído dentro das aulas de Matemática. Assim, existe uma impressão (falsa) de que a Estatística é Matemática, assunto que está mais detalhado em 3.3 na página 30.

Já em Brasil (1998), Spiegel (2006) e Magalhães e Lima (2011) a Estatística é caracterizada como o conjunto dos procedimentos para coletar, organizar, comunicar e interpretar dados, utilizando tabelas, gráficos e representações presentes no cotidiano de muitas pessoas. Para desenvolver algumas das ideias básicas da Estatística é necessário estabelecer relações entre grupos de interesse e partes desses grupos de interesse do qual dispomos para observar características e padrões, de modo a obter informações úteis. Isto nos remete aos conceitos de população e amostra, que são apresentados logo em seguida de acordo com as definições de Chalmer (1987) e Moore (2000).

População: Refere-se ao conjunto dos elementos de interesse, ou seja, uma coleção que contém todos os elementos que se pretende analisar.

Amostra: Refere-se ao subconjunto da população, ou seja, uma coleção que contém uma parte dos elementos que se pretende analisar.

Para Moore (2000), a expressão "parte dos elementos" merece cuidado ao ser tratada, pois é responsável por alguns erros conceituais encontrados entre as pessoas que estudam ou até mesmo que ensinam Estatística. Uma amostra é qualquer subconjunto não vazio formado por elementos da população em estudo. Além do número de elementos, a qualidade da amostra também tem diversas implicações em todas as etapas que sucedem a sua coleta e por isso é de fundamental importância para não comprometer a análise dos dados.

Na maioria das situações, tanto por questões de custo, como de tempo e mesmo por dificuldade de acesso aos elementos de uma população, torna-se clara a necessidade de se trabalhar com amostras.

Examinar amostras é algo presente também em algumas situações cotidianas. É o que acontece quando averiguamos a quantidade de sal numa panela de arroz, provamos um pouco e deduzimos sobre a condição de sal de todo o alimento. $\mathrm{O}$ mesmo acontece com os testes para fraude em combustível. Uma pequena amostra e sabemos como está a condição de todo o combustível do reservatório. Nesses casos as amostras preservam fortemente as mesmas características e proporções da população devido à homogeneidade encontrada, o que torna dispensável a análise de toda população, que quase nunca é analisada. Essa homogeneidade também facilita estender as conclusões obtidas sobre a amostra para população.

Existem casos em que as características a serem observadas da população em estudo, ao invés de terem o comportamento homogêneo citado no parágrafo anterior, apresentam heterogeneidade, que se espera seja retratada na amostra e que exigirá uma análise mais cuidadosa.

Como o interesse de uma pesquisa é sobre os aspectos populacionais, ć comum fazer afirmaçõcs, julgamentos, conclusões sobre populações utilizando informações extraídas de uma amostra. A utilização de informações parciais pode gerar conclusões imprecisas que podem ou não conduzir a conclusões corretas. Essa passagem, da parte para o todo, que carrega a imprecisão nos resultados, 
utilizada nos procedimentos formais, é mediada pela probabilidade.

Para Chalmer (1987) são diversos os motivos que podem comprometer as afirmações feitas a partir de uma amostra sobre uma população. Além da variabilidade, o autor destaca os erros cometidos ao se transcrever respostas, erros em cálculos e em medidas.

De acordo com Moore (2000), para possibilitar o levantamento de informações válidas a partir de dados que possam responder questões específicas sobre um grupo maior é necessário cuidados especiais para gerar dados e também para analisá-los. Existem técnicas para a coleta e tratamento de dados que aumentam a confiabilidade dos dados e também as possibilidades de estender as conclusões sobre os dados para grupos maiores.

Esse tipo de relação entre a amostra e população tem se mostrado um dos assuntos mais profundos da Estatística e é estudado dentro de uma área denominada Inferência Estatística, tratada no Capítulo 5.

A palavra conceito está relacionada com uma definição, concepção, caracterização de um determinado tema ou ideia. Ter um conceito sobre algo implica em poder explicá-lo por meio de palavras ou de outras representações.

Segundo Severino (2007), um conceito pode ser representado linguisticamente por um termo ou palavra. A compreensão de um conceito pode ser manifestada pelo domínio de um conjunto de características específicas, relacionadas ou não, que auxiliam no entendimento do objeto pensado.

Em Brasil (1997) não consta quais conceitos devem ser desenvolvidos nas aulas de Estatística mas, a escolha deles é norteada pelo trecho a seguir, que descreve as habilidades básicas de um cidadão:

"... fazer observações sistemáticas de aspectos quantitativos e qualitativos do ponto de vista do conhecimento e estabelecer o maior número possível de relações entre eles, utilizando para isso o conhecimento matemático (aritmético, geométrico, métrico, algébrico, estatístico, combinatório, probabilístico); selecionar, organizar e produzir informações relevantes, para interpretá-las e avaliálas criticamente."

Diante disso, é possível deduzir alguns conceitos principais que estão envolvidos na aquisição e desenvolvimentos dessas habilidades.

\section{$2.1 \quad \mathrm{O}$ que é um conceito fundamental}

De acordo com Ferreira (2000), "conceito" remete em sua origem etimológica à "coisa concebida" ou "formada na mente". Um conceito também pode ser algo que se concebe no pensamento sobre algo ou alguém. É a forma de pensar sobre algo, é uma opinião manifesta, é um símbolo mental, um conjunto de características comuns que determinam como as coisas são.

De acordo com Burril e Biehler (2011) podemos considerar como alguns dos alicerces da Estatística os seguintes conceitos: dados, variação, distribuição, representação, relações entre variáveis, planejamento e coleta de dados, amostra e inferência. Embora exista diferenças entre autores do que seja considerado um conceito ou um procedimento, os tópicos, se podemos assim chamar, são indispensáveis para a compreensão dos procedimentos iniciais da Estatística.

Um conceito fundamental remete à ideia de básico, de alicerce, de indispensável para fundamentação das ideias essenciais da Estatística. Por serem fundamentais ou básicas têm chamado a atenção às dificuldades que envolvem sua compreensão, que serão discutidas abaixo. 
Sobre os conceitos fundamentais, Machado (2009) descreve duas características inerentes a eles: a primeira é que um conceito fundamental articula várias partes de um tema e a segunda é que um conceito fundamental transborda os limites de um tema possibilitando a conexão com outros temas. Em alguns casos a importância com que um conceito é discutido em uma disciplina não é proporcional à sua verdadeira importância, como no caso da aleatoriedade e sua presença nos currículos.

Falhas nos processos educacionais ocorreram ao longo da história. Devido a isso, existem pessoas, quando alunos do nível básico, que passaram por experiências pouco frutíferas no tema.

Moore (2000), com base em estudos publicados no meio acadêmico, também relata fenômeno semelhante e destaca que a persistência talvez seja o princípio de todo aprendizado. Os assuntos importantes e ideias fundamentais precisam de tempo para serem completamente dominados tanto no campo da Estatística quanto em outras áreas do conhecimento.

Algumas dificuldades e erros conceituais são mais comuns que outros e por isso os professores podem se preparar antecipadamente para enfrentá-los. Segundo Batanero (2001), quando se trata de procedimentos estatísticos o mesmo ocorre. As primeiras tentativas de tabular dados podem ser difíceis para alunos que não conseguem resumi-los de alguma maneira e alguns podem questionar sobre a utilização de intervalos de classes. Quando se constrói gráficos costuma-se observar uma escala bem dimensionada para elucidar o entendimento e diminuir possíveis erros envolvendo proporção. Também são esperados diferentes níveis de compreensão de um gráfico por parte dos alunos, nível que acompanha o conhecimento de cada um deles.

Diante de um problema é possível abordar um ou mais conceitos, dependendo dos conhecimentos que os alunos apresentam e também de acordo com as intenções do professor. Focar apenas um ou relacionar diversos aspectos é uma escolha do professor que depende de seus objetivos pedagógicos e das condições que os alunos apresentam ligadas aos conhecimentos necessários, inclusive de livros didáticos.

Segundo Pfannkuch (2006) existem erros conceituais de alunos na elaboração de conclusões sobre um conjunto de dados, com grandes dificuldades relacionadas a verbalização e escrita dos argumentos utilizados para justificar afirmações. Essas dificuldades têm preocupado muitos especialistas da área da Educação Estatística e um grande esforço tem sido feito para identificar suas causas e também encontrar uma maneira mais eficaz de ensinar os conceitos fundamentais da Estatística. Sabemos que não há uma regra geral que possa ser aplicada nas classes e que resolva todas as dificuldades, mas existem características comuns encontradas entre os alunos, independentemente da idade e do país e que são objeto de pesquisa ligada aos processos de ensino e aprendizagem.

\subsection{Erros Conceituais}

De acordo com Campbell (1974), os primeiros erros conceituais surgiram juntamente com as primeiras utilizações da Estatística, ainda em tempos antigos, sem uma data precisa. Atualmente as falácias estatísticas estão cada vez mais presentes em jornais, revistas, propagandas e conversas.

Segundo o autor, isso está ocorrendo devido ao pouco entendimento dos métodos e técnicas formais de análise exploratória de dados e pode ser prejudicial para o exercício da cidadania. Isto dificulta o espírito crítico do leitor.

Quando estamos aprendendo algo, o erro é inevitável e pode ser interpretado como uma etapa do 
aprendizado, como um caminho para buscar o acerto. De acordo com Brasil (1998), quando existe um erro conceitual, o aluno faz tentativas, à sua maneira, construindo uma lógica própria para encontrar a solução. Diante disso, o professor pode identificar, mediante a observação e o diálogo, como e o que o aluno está pensando. Dessa maneira é possível levantar evidências do que não foi compreendido e auxiliá-lo, pois existem diferentes fatores que podem gerar um erro.

Esses erros podem ser decorrentes de bloqueios do próprio aluno, que impedem o desenvolvimento de conceitos, muitas vezes pelo fato de a abordagem não ser adequada ao momento educacional dos estudantes.

Bloqueios e mesmo outras rupturas que ocorrem naturalmente nos processos educacionais são descritos como obstáculos por Brousseau (2008) e, apesar de não prosseguirmos aqui neste trabalho com a sua teoria, vamos destacar a classificação por ele proposta para os obstáculos: epistemológicos, didáticos, psicológicos e ontogênicos. Alguns exemplos serão apresentados para exemplificar.

Como exemplo de um obstáculo epistemológico, que é ligado ao conhecimento, podemos considerar um aluno sem conhecimentos matemáticos relativos a ângulos. Dado um conjunto de dados, esse aluno é capaz de obter um gráfico de setores utilizando um software. Se forem oferecidos a esse mesmo aluno outros recursos, como lápis de cor e um transferidor, ele poderá não saber como obter gráfico de setores. Isso ilustra um pouco sobre o obstáculo uma vez que é o conhecimento (no caso a falta de conhecimento relativo a ângulos) o fator que impede o desenvolvimento.

Podemos citar erros que persistem em alguns alunos e que são de natureza epistemológica dentro do ensino da Matemática:

$$
\frac{1}{5}+\frac{1}{4}=\frac{2}{9} ; \quad(a+b)^{2}=a^{2}+b^{2} ; \quad 2^{3}+2^{5}=2^{8}
$$

Dentro do ensino de Estatística os erros de natureza epistemológica podem ser exemplificados por:

$\bar{X}($ média amostral $)=3 \Rightarrow \mu($ média populacional $)=3 ;$

Não rejeitar que dois grupos tenham médias iguais $\Rightarrow$ assumir que os dois grupos tenham médias iguais.

Quanto aos obstáculos didáticos o autor os caracteriza pelo fato de que são, de certa forma, dependentes das escolhas feitas ao longo do processo de ensino.

Sob esse olhar, podemos exemplificar como obstáculo didático o ensino da variabilidade, usando unicamente a definição teórica de variância, por meio da expressão:

$$
\sigma^{2}=\frac{1}{n} \sum_{i=1}^{n}\left(x_{i}-\mu\right)^{2}
$$

De acordo com o momento educacional do aluno, a definição formal pode não ter significado, pois exige, para sua compreensão, conhecimentos mais elaborados.

Os obstáculos ontogênicos estão ligados a limitações e características de cada aluno (sua maturidade) e se relacionam ao desenvolvimento neurofisiológico.

A construção do conhecimento também ocorre diante dos erros e dos obstáculos. O aluno também aprende corrigindo os erros e, da mesma forma, antecipando seus efeitos. Dessa maneira pode 
substituir alguns conhecimentos por outros mais adequados. Nesse sentido, Brousseau (2008) considera que situações e atividades sem algum erro perdem seu conteúdo didático e poderiam ser consideradas perda de tempo.

Em Sotos et al. (2007) podemos encontrar uma análise sobre os erros conceituais mais frequentes em suas pesquisas; os principais se relacionam ao espaço amostral, à variabilidade em amostras pequenas, às diferenças entre população e amostra e às relações com a variabilidade, distinções entre casos particulares e generalizações, efeitos do tamanho da amostra, comparação de duas distribuições diferentes, nível de significância, teorema central do limite, definições de hipóteses, mecanismo do teste de hipóteses, encadeamento de informações que validem ou afetem a conclusão de uma Inferência Estatística.

Nem todos os itens citados são conceitos fundamentais propriamente ditos, mas todos eles possuem um aspecto básico dentro da aplicação e do estudo da Estatística. Na escola básica, alguns desses itens estão presentes no currículo, o que não impede que existam alunos que chegam ao ambiente universitário sem os princípios mais rudimentares dessa área. Alguns autores, como Ben Zvi e Garfield (2004) e Pfannkuch (2006), atribuem essa condição a falhas que ocorrem durante o ensino básico e estão relacionadas com abordagens mecanizadas, distantes dos conceitos elementares e da análise exploratória de dados.

Ben Zvi e Garfield (2004) relatam que no ensino básico, ocorrem as mesmas dificuldades. Muitas vezes esses problemas têm suas raízes nas práticas deficientes executadas sem o devido planejamento ao longo dos anos do ensino básico.

\subsection{Algumas Ideias Fundamentais da Estatística}

As ideias consideradas fundamentais na Estatística estão ligadas aos conceitos básicos dos quais derivam as teorias, técnicas e procedimentos estatísticos. Compreender essas ideias é uma necessidade para que seja possível fazer inferências corretas sobre dados nos ambientes escolares, profissionais e também em nossa vida particular pois, cada vez mais, a mídia e as necessidades sociais nos disponibilizam dados e informações estatísticas.

\subsubsection{Dados}

Dados estatísticos são informações coletadas que servem como base para um estudo estatístico. Eles podem ser obtidos por meio de observações documentadas, resultados de uma medição ou de outras formas. Quando apresentados de forma sintética e organizada são classificados simplesmente como dados. Quando os dados coletados não foram resumidos ou organizados de forma sistemática são considerados dados brutos.

De acordo com Hand (2008) os dados estatísticos são tipicamente números resultantes de contagens, mensurações ou outros processos. Para ele, a importância dos dados se justifica pela sua função de representar. O processo de transformar as informações de um problema em números é a etapa inicial de qualquer estudo estatístico. Em outras palavras, gerar dados significa encontrar uma representação numérica para o que se deseja estudar para então fazer um estudo estatístico sobre as características, tendências e informações percebidas por meio dos números e que não foram percebidas por meio de uma representação não numérica. 
É comum encontrar situações que não produzem dados numéricos diretamente. Palavras, depoimentos, relatos, sinais eletrônicos, enfim, ncssas situações é necessário que haja uma quantificação adequada.

A utilização e escolha dos procedimentos para organizar e descrever dados depende de algumas características que estes apresentam. De acordo com Magalhães e Lima (2011), os dados podem ser classificados em dois grandes grupos: numéricos e não numéricos. Esse distinção se reflete no emprego dos termos quantitativo e qualitativo, respectivamente.

Dados qualitativos remetem a atributos que representam qualidades, caso seja possível uma ordenação desse tipo de dado podemos classificá-lo como qualitativo ordinal, caso contrário, será classificado como qualitativo nominal. É o que acontece com dados que assumem, por exemplo, níveis de satisfação, feminino/masculino, sim/não, etc.

Os dados quantitativos podem ser contínuos como peso, altura, tempo, etc. Podem ser ainda discretos como no caso do número de filhos, número de atendimentos em uma loja, unidades fabricadas em uma linha de produção, etc.

Existem formas mais adequadas de representação do que outras, conforme cada tipo de dado. Quando representam variáveis qualitativas, uma maneira comum é descrevê-los por meio de frequências. Já os dados que apresentam características quantitativas podem ser expressos por meio de medidas descritivas. Para Batanero (2001) a aprendizagem depende das representações disponíveis e se são adequadas ou não ao estágio de conhecimento do aluno.

Além disso, a confecção de tabelas e gráficos depende diretamente dos dados. A escolha da forma correta de representação para analisar os dados pode facilitar a confeç̧ão desses recursos. Para Hand (2008) dados com qualidade, que representam bem um fenômeno oferecem condições de se obter uma conclusão. Dados de baixa qualidade, que não representam adequadamente um fenômeno, não oferecem a possibilidade de se obter uma conclusão, sendo praticamente inócuos.

Devido ao exposto acima pode-se constatar que o estudo envolvendo a coleta de dados é importante, pois influencia todas as etapas seguintes. Essa condição demandou a criação de uma área específica da Estatística para planejamento das formas mais eficazes de coleta e obtenção de dados.

Assim como os dados, alguns autores não consideram a população e amostra como sendo conceitos propriamente ditos, mas devido à sua relação intrínseca com o entendimento da variabilidade também será tratada em uma subseção específica.

O mesmo ocorre com a aleatoriedade, que não é considerada um conceito propriamente dito embora seja inerente a todo processo estatístico. Batanero (2001) chama a atenção para o fato de alguns autores considerarem o termo "aleatoriedade" ligado a várias ideias e mostra algumas classificações que podem ser aplicadas aos fenômenos aleatórios: aqueles em que os resultados são equiprováveis; os que têm múltiplas possibilidades; a aleatoriedade como falta de causalidade; como incerteza ou ainda como parte de modelos matemáticos nos quais estão apoiados alguns procedimentos estatísticos.

De acordo com a autora é esperado dos alunos que estes sejam capazes de diferenciar resultados e padrões gerados por mecanismos aleatórios ou não aleatórios.

\subsubsection{População e Amostra}

Como já definidas anteriormente, população é o conjunto dos elementos sobre o qual pretendemos obter informações enquanto que a amostra é um subconjunto da população que é investigado 
efetivamente a fim obter as informações desejadas sobre a população. Isso pode ser ilustrado na seguinte Figura ${ }^{1}$ :

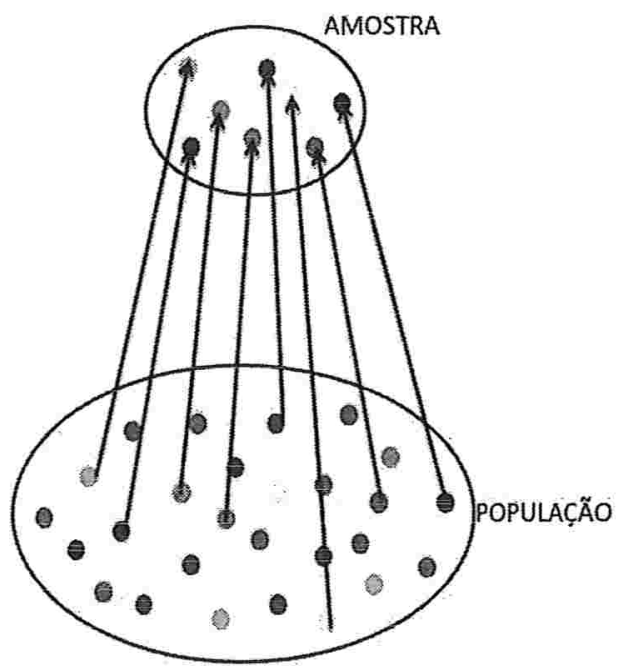

Figura 2.1: População e Amostra

Os procedimentos ligados à análise exploratória de dados estatísticos buscam extrair informações dos dados por meio de resumos numéricos e dispositivos gráficos. As conclusões são feitas sobre uma amostra, ou seja, utilizando os dados que temos em mãos mas, frequentemente, necessitamos estender as conclusões para um conjunto maior, a população. Para que isso seja possível é necessário que os dados em mãos representem adequadamente esse grupo maior, caso contrário não podemos estender nossas conclusões. Moore (2000)

As técnicas de amostragem são utilizadas para obter amostras que tragam informações necessárias sobre a população e a Inferência Estatística auxilia na análise dessas informações e fornece meios de verificar quão confiáveis são as conclusões estendidas para população e que consideram os dados amostrais.

Tanto nessa figura quanto na própria definição de amostra, é possível perceber a possibilidade de extrair diferentes amostras de uma mesma população e que essas diferentes amostras podem revelar informações diferentes, gerando incertezas e também a possibilidade de conclusões diferentes. Para minimizar essa condição e diminuir a incerteza dos processos estatísticos, existem técnicas específicas de planejamento para coleta de dados e para realização de experimentos estatísticos que geram dados.

A ausência de planejamento ou um planejamento mal elaborado do processo de coleta de dados podem favorecer sistematicamente certos resultados e tornar o estudo tendencioso. A alternativa mais utilizada para combater a tendenciosidade das pesquisas estatísticas é obter uma amostra aleatória em que todos os elementos da população têm a mesma chance de constituir a amostra. Assim é possível coletar os dados de maneira que não haja favoritismos nem qualquer tipo de influência pessoal, sejam estas influências por parte do pesquisador ou por parte dos pesquisados. Moore (2000)

\footnotetext{
${ }^{1}$ disponível em http://xeqmat1.webnode.pt/estatistica/população-amostra/
} 
Para Moore (2000), mesmo tomando todas as precauçães para minimizar os erros e tendenciosidades que podem surgir nas várias etapas dos procedimentos estatísticos espera-se que os resultados de uma amostra sejam diferentes dos resultados da população (temos uma parte do todo). Quando obtemos uma amostra a partir de um procedimento aleatório sabemos que os diferentes resultados gerados pelas diferentes amostras seguem as leis da probabilidade. A partir desse fato é possível calcular a probabilidade dos erros que podem ser cometidos ao se estender conclusões de uma amostra para a população.

Em inferência, uma das principais ideias é que uma amostra fornece informações sobre a população. Para entender as propriedades fundamentais dos processos de amostragem é necessário encontrar um equilíbrio na relação entre dois outros conceitos: variabilidade e representatividade da amostra. Sotos et al. (2007)

Alguns erros previsíveis circundam o entendimento do conceito de representatividade da amostra. Esses erros dão origem a noções erradas sobre os procedimento de coleta de uma amostra gerando falsos conceitos e concepções erradas.

Harradine et al. (2011) consideram representatividade amostral um conceito que necessita de entendimento pleno. A distinção entre amostra e população é encorajada por diversos currículos em diferentes países. Diante disso, chamam a atenção para necessidade de se compreender dois conceitos muito próximos: representatividade amostral e variabilidade amostral.

Segundo os últimos autores, muitas das dificuldades apresentadas pelos alunos podem ser devido à utilização de uma única amostra para se explorar o assunto. É necessária a utilização de mais de uma amostra para explorar esses conceitos uma vez que ambos estão relacionados às muitas possibilidades de se extrair uma amostra de uma população.

\section{As Desvantagens de uma Amostra Pequena}

De acordo com Sotos et al. (2007), um dos erros conceituais ligados à compreensão da representatividade de amostra é a falsa intuição de que uma amostra sempre apresenta as mesmas características da população de onde foi coletada. Isso não é necessariamente verdade mas pode ocorrer.

Outro erro é a crença de que duas amostras quaisquer de uma mesma população são iguais ou muito parecidas entre si, o que também não é necessariamente verdade. Essas duas considerações sobre amostras são erros conceituais graves e quando incorporadas a uma análise exploratória de dados para fazer generalizações sobre uma população pode conduzir, e geralmente conduz, a conclusões enganosas.

Uma situação que exemplifica esse tipo de abordagem, por meio de amostra de tamanho pequeno é a seguinte:

Para verificar antecipadamente sua produção, um agricultor deseja saber quantas batatas deve pesar para determinar o peso médio das batatas da lavoura? Inicialmente ele desenterra uma batata e pesa, anotando o resultado: $72 \mathrm{~g}$.

Diante disso é necessário um auto questionamento sobre esse procedimento. Será podemos afirmar que as batatas da lavoura pesam em média $72 \mathrm{~g}$ ? Será que essa batata é grande quando comparada às outras ou será que é pequena quando comparadas às outras?

Insatisfeito o agricultor desenterra outra batata e pesa: $130 \mathrm{~g}$.

Agora a amostra possui dois elementos e a média amostral dada por $\frac{72+130}{2}=101$. Novamente é 
necessário um questionamento por parte dos alunos sobre as mesmas questões. É plausível afirmar que em média as batatas da lavoura inteira pesam 101g? Essa batata de 130g pode ser considerada pesada ou existem batatas mais pesadas?

Esse tipo de abordagem exige reflexão sobre o caso em que temos uma amostra com três elementos, quatro elementos e assim por diante até que o aluno questione sobre qual o número mínimo de batatas para determinar a média da lavoura.

Outra situação a ser explorada é sobre a igualdade entre amostras com mesmo número de elementos: Será que a amostra contendo três batatas coletadas pelo agricultor apresentará uma média de peso igual a média de uma outra amostra composta por três batatas coletadas por outra pessoa?

Essa situação pode ser reproduzida em sala com batatas fornecidas pelos alunos e as situações verificadas diretamente com a pesagem das batatas disponibilizadas.

Embora os elementos das amostras sejam, na maioria das vezes, considerados homogêneos pelos alunos, alguns contextos podem apresentar conotações de heterogeneidade e confundir alguns alunos. Assim como Sotos et al. (2007), Reading e Shaughnessy (2004) chamam a atenção para a grande quantidade de conflitos envolvendo a ideia de representatividade amostral. Para esses autores, alguns desses conflitos se resolvem quando há problematizações envolvendo todas as possibilidades de uma amostra, de um mesmo tamanho. Um exemplo é:

Qual é a quantia média de dinheiro que um brasileiro carrega no bolso?

Quantas pessoas deveriam ser entrevistadas para se obter uma resposta confiável?

Entrevistar todas as pessoas de uma mesma classe social seria suficiente para se concluir sobre a quantia média de dinheiro que brasileiro carrega no bolso? Um grupo de pessoas da região sul do país teria a mesma média que uma grupo de pessoas da região norte do pais? Entrevistar pessoas no início do mês pode apresentar resultados diferentes das pessoas entrevistadas no final do mês?

Esses são exemplos de questionamentos a se fazer que podem estimular os alunos a pensarem nas possibilidades de amostras e suas implicações sobre as conclusões sobre a população.

Uma amostra pequena não diz muita coisa, mas comumente esse fato é desconsiderado. Sotos et al. (2007) e outros autores chamam a atenção para os problemas gerados pela grande incerteza encontrada em uma pequena amostra.

Entender as relações entre o tamanho da amostra e a incerteza é um processo que depende do conceito de variabilidade. Além disso a ponderação das informações por meio de uma medida probabilística exige uma certa habilidade para se relacionar diversos conceitos.

Em alguns casos, pessoas tomam decisões analisando uma amostra contendo apenas um elemento. Experimentando uma uva para confirmar se o cacho está bem doce ou cm uma amostra de sangue para exame. Nesse caso vale observar a homogeneidade da população. Nesses casos o cacho de uva e todo sangue do corpo seriam populações.

Quando a população apresenta-se mais heterogênea, com uma variabilidade maior, isso evidencia que os elementos que compõem a amostra apresentarão maior diversidade entre si. Nesse caso amostras pequenas são pouco confiáveis, em alguns casos nem um pouco confiáveis. Por exemplo; para saber qual o gosto musical do brasileiro, utilizar a opinião somente de um vizinho. Certamente, independente do gênero predileto desse vizinho, ele não representaria o gosto musical brasileiro. Perguntar a um grupo de amigos também não é uma boa ideia pois existe uma proximidade grande entre os elementos que compõem a amostra. 


\section{As Vantagens de uma Amostra Grande}

Se utilizarmos os dados de uma população para obter informações certamente não haveria problemas com a incerteza porém algumas populações são muito grandes, o que acarreta custo elevado para coleta dos dados. Outra circunstância que limita o número de elementos de uma amostra é o orçamento disponível para a realização de uma pesquisa tornando necessário diminuir a precisão desejada ou, caso não seja possível atingir uma precisão satisfatória não realizar a pesquisa.

Determinar o número de elementos de um amostra implica em pensar como coletá-la de maneira fácil. Quantas pessoas necessárias, quanto tempo será gasto, qual a disponibilidade e distribuição da(s) fonte(s) de informação(ões). Em alguns casos são utilizados estudos empíricos mas nem sempre isso é possível.

Verificar isso por meio de lançamentos de uma moeda ou dado é praticável. Dividir os alunos em grupos pode agilizar muito alguns tipos de experimentos e tornar observável a convergência das probabilidades para o seu valor teórico no caso de lançamentos de uma moeda. Quando possível, a utilização de uma planilha, no computador, que calcule as probabilidades também pode facilitar a execução desse tipo de experimento, sem deixar de mencionar a importância de se fazer isso à mão.

\subsubsection{Medidas Descritivas}

Os dados (observações coletadas) são a matéria prima da Estatística e se referem a características de interesse do estudo e/ou pesquisas. As medidas descritivas em Estatística, comumente chamadas de medidas resumo, dizem respeito a como descrever os dados de natureza quantitativa (variáveis quantitativas) por meio de números. Existem muitas medidas descritivas que são usadas em diversas situações porém, para descrever uma distribuição, é aconselhável incluir uma medida de posição e uma medida de variabilidade, que serão descritas a seguir, o que torna fundamental a compreensão dessas.

De acordo com Magalhães e Lima (2011), essas medidas buscam sumarizar as informações disponíveis e facilitam a percepção de algumas características sobre o comportamento dos dados.

Como já dissemos, algumas das medidas descritivas visam resumir os dados observando a posição dos elementos da amostra, e entre essas medidas, conhecidas como medidas de posição, destacam-se a média, a mediana, a moda, os quartis e os percentis. As medidas conhecidas como sendo de dispersão tendem a resumir os dados observando as diferenças numéricas entre eles ou distâncias em relação a alguma referência, sendo que as mais comuns são a amplitude, o intervalo interquartil, a variância e o desvio padrão. Essas medidas-resumo são utilizadas nos diversos campos do conhecimento e podem ser calculada facilmente, por meio de operações matemáticas elementares.

Estudos de Konold e Pollatsek (2002) e também de Pfannkuch (2006) destacam que os alunos sabem como calcular as medidas resumo mas não sabem o que fazer com elas depois que as calculam. Apenas alguns poucos alunos as utilizam para caracterizar o conjunto de dados e fazer comparações entre conjuntos de dados. Essa situação, que é uma forte evidência da existência da falta de entendimento dos conceitos envolvendo as medidas descritivas, é descrita por vários professores quando se referem a algumas salas nas quais atuam. 


\section{Medidas de Posição}

Neste trabalho vamos mais além, definindo outras medidas e, principalmente, deixando claro que medidas de posição nunca devem prescindir de medidas de variabilidade.

Vamos aqui exemplificar o cálculo das medidas-resumo acima referidas usando as alturas (em $\mathrm{cm}$ ) de alunos sorteados em uma classe do fundamental II de uma escola da capital de São Paulo. Podemos usar a nomenclatura de estatística e dizer que a variável em estudo é a altura de alunos e que temos uma amostra de sete alunos com alturas $(\mathrm{em} \mathrm{cm}) 138,142,140,145,135,133$ e 137. Chamemos este conjunto das alturas de A.

Começando pelas medidas de posição, vamos calcular média, mediana, moda e quartis e depois discutir os resultados, bem como apresentar, em determinados momentos, comentários ligados ao ensino propriamente dito.

Vamos iniciar a discussão para a variável "altura" e depois ampliaremos para outros casos. Assim, usando os dados coletados das alturas dos alunos temos:

Média: soma dos valores dividida pelo número de valores

$$
\frac{(138+142+140+145+135+133+137)}{7} \approx 138,6
$$

De uma maneira mais formal a média pode ser representada pela expressão

$$
\bar{x}=\frac{x_{1}+x_{2}+x_{3}+\cdots+x_{n}}{n}=\frac{1}{n} \sum_{i=1}^{n} x_{i}
$$

Mediana: valor que deixa o mesmo número de valores à sua direita e à sua esquerda; corresponde ao valor central depois dos dados ordenados, que no caso do conjunto A é igual a $138 \mathrm{~cm}$, ou seja

$$
133,135,137,138,140,142,145
$$

Podemos também considerar a mediana como um valor que separa duas metades dos dados colocados em ordem. Por isso é considerada uma medida de centralidade. Para Moore (2000) esse é o conceito: um número que separa os dados em partes que possibilitem a comparação.

Enquanto a média tem um algoritmo simples para cálculo, a mediana, até mais simples em termos de cálculo, chama a atenção pelas dificuldades que permeiam o entendimento do seu significado (principalmente pela compreensão de ordenação dos dados) o que ocasionam os erros que os alunos cometem ao tentarem obter seu valor.

O que ocorre em muitos livros didáticos para se obter a mediana é a divisão em dois casos (número impar de observações ou número par de observações), cada caso sendo associado a um algoritmo distante do conceito. Esses livros focam somente o modo de se obter o valor da mediana deixando de lado a utilidade da mesma para ajudar a caracterizar uma amostra. Uma maneira de esclarecer os dois casos é oferecer aos alunos exemplos simples que representem a ideia de mediana. e não apenas os algoritmos para obter seu valor.

Exemplos numéricos, quando simples, podem ajudar alguns alunos a entenderem os conceitos e constatarem que existem situações com número par e situações com número ímpar. Em alguns casos é necessário mostrar vários exemplos para que os alunos assimilem o conceito.

Uma alternativa para os impedimentos que os exemplos numéricos carregam é oferecer um exemplo concreto de mediana por meio de uma fila de alunos em que a característica de interesse 
seja a altura desses alunos. O professor pode selecionar alguns alunos e formar uma fila por ordem de tamanho para que os demais visualizem o elcmento da fila que possui altura mediana, ou seja, o elemento central da fila. Com alguns exemplos de filas com números pares e ímpares de alunos é possível facilitar o entendimento do conceito de mediana frente às dificuldades pertinentes a esse tema, além disso, os exemplos concretos fortalecem o entendimento e contribuem para assimilação do assunto sendo útil mesmo para quem entende facilmente exemplos numéricos.

Por meio de uma fila ordenada por altura podemos ilustrar a ideia de mediana:

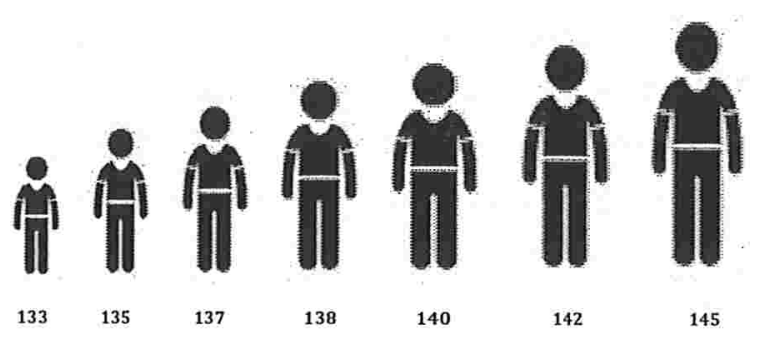

Figura 2.2: Exemplo de Fila Ordenada

Voltando aos dois casos: quando o número de elementos de uma amostra é ímpar a mediana é o próprio valor do elemento central como já vimos acima no caso das 7 alturas, ou seja: $m d_{A}=138$. Supondo o conjunto $B$ sem o menor elemento de $A, B=\{135,137,138,140,142,145\}$ qual o valor da mediana? Nesse caso não há um elemento central e sim dois elementos centrais, então a mediana é qualquer valor que poderia assumir a posição central entre os elementos de B. É convencionado $m d_{B}=139$ que é a média entre os dois elementos centrais de B (138 e 140) ou qualquer valor nesse intervalo pois separaria o conjunto em duas partes, cada uma com $50 \%$ dos valores maiores e $50 \%$ dos valores menores do que o valor da mediana. Como notação para mediana pode ser utilizado $Q_{2}$ ou $Q_{50 \%}$, como veremos mais adiante.

Essas duas medidas (média e mediana) são largamente empregadas em uma série de situações. A média utiliza todas as observações e assim, qualquer mudança em um elemento ou a presença de valores discrepantes refletirá no cálculo do seu valor. Embora não seja tão difundida e utilizada, a mediana por utilizar apenas o valor central (ou dois centrais) é de fácil obtenção e além disso tem a qualidade de robustez, ou seja, diferentemente do que acontece com a média, a mediana não se deixa afetar por valores aberrantes, e seu uso favorece em algumas situações uma interpretação mais realista do que a média para representação de uma determinada característica. Por exemplo, dados os conjuntos $\{1,2,3\},\{1,2,4\},\{1,2,8\}$ a mediana é a mesma para todos eles, o que não é verdade para as médias.

Existe uma diferença conceitual importante entre as medidas de posição média e mediana. Para calcular a média utilizamos todos os elementos da amostra. Assim, qualquer mudança em um elemento ou a presença de valores discrepantes refletirá no valor da média. Já a mediana utiliza apenas o valor central, ou dois centrais quando a amostra conter um número par de elementos, para ser calculada. Assim, mudanças em quaisquer valores ou a existência de pontos discrepantes não refletem no valor da mediana. Devido a essa diferença alguns países calculam a inflação por valores médios enquanto outros calculam a inflação por valores medianos, o que acarreta, em alguns casos, uma diferença enorme em termos de quantidade de inflação medida, quando comparadas as duas 
possibilidades.

Segundo Moore (2000), apesar de serem medidas de posição, média e mediana podem revelar características sobre o comportamento de uma amostra quando comparadas entre si. Quando a distribuição é aproximadamente simétrica os valores da média e da mediana são próximos. Em uma distribuição exatamente simétrica os valores da média e da mediana coincidem. Por conseguinte, quando os valores da média e mediana são muito diferentes é um indício de que a distribuição da amostra seja assimétrica. A diferença entre os valores dessas medidas pode ser causada pela existência de valores extremos.

Tanto a média quando a mediana são medidas de posição que representam os dados mas seus valores numéricos não precisam, necessariamente, compor a amostra com mesmas características nem possuir valores iguais para medidas. Quando dizemos que casais de certa localidade têm em média 1,7 filhos por casal, sabemos que nenhum casal vai ter 1,7 filhos pois o número de filhos de um casal pertence ao conjunto dos números naturais, $\mathbb{N}$. O que podemos dizer é que há mais casais que têm 2 filhos ou mais, do que casais que têm apenas 1 filho pois o número 1,7 está mais próximo de 2 do que de 1 , ou seja, o centro está mais próximo de 2 do que de 1.

Um exemplo que ilustra um tipo de engano induzido pela utilização única da média é percebido quando tratamos da renda média do brasileiro, que é em torno de $R \$ 1.052,00 \mathrm{em} \mathrm{2014.}{ }^{2}$

Com relação à mediana também podem ocorrer erros de interpretação quando esta é analisada isoladamente. Diante das amostras $\mathrm{A}=\{100,300,500\}, \mathrm{B}=\{299,300,301\}, \mathrm{C}=\{50,300,1000\}$, temos que as medianas de A, B e C são iguais. Contudo, se observarmos a variabilidade dos valores em cada conjunto perceberemos uma grande desigualdade entre as distribuições dos valores.

Outra medida de posição presente amplamente utilizada, inclusive pela simplicidade, é a moda.

Moda: valor mais frequente.

Outras medidas de posição muito utilizadas na Estatística descritiva para caracterizar um conjunto de dados são os quartis.

Quartis: como o nome indica, são valores que dividem o conjunto de valores em quartos (4 grupos com $25 \%$ de observações cada um).

Para a divisão em grupos com $25 \%$ de observações cada um, precisamos de três valores. A saber: $1^{\circ}$ quartil, $Q_{1}$ ou $Q_{25 \%}$ (valor que deixa $25 \%$ de valores menores ou iguais a ele); $2^{\circ}$ quartil, $Q_{2}$ ou $Q_{50 \%}$ que é a mediana, já vista (valor que deixa $50 \%$ de valores menores ou iguais a ele) e $3^{\circ}$ quartil $Q_{3}$ ou $Q_{75 \%}$ (valor que deixa $75 \%$ de valores menores ou iguais a ele).

Para construir os quartis utiliza-se uma ideia próxima daquela usada para o cálculo da mediana. Para calcular $Q_{25 \%}$ que possui $25 \%$ dos valores menores ou iguais a $Q_{25 \%}$ e $75 \%$ dos valores maiores do que $Q_{25 \%}$ dividimos o conjunto ordenado dos 7 valores das alturas em 2 conjuntos de 4 valores cada um, da seguinte maneira:

Em seguida calculamos a mediana de cada grupo. A do primeiro grupo será o $1^{\circ}$ quartil, $Q_{1}$, do grupo todo e a do segundo grupo será o $3^{\circ}$ quartil, $Q_{3}$, do grupo todo.

\footnotetext{
${ }^{2}$ http://g1.globo.com/economia/noticia/2015/02/renda-domiciliar-capita-do-brasil-foi-de-r-1052-em-2014-dizibge.html
} 


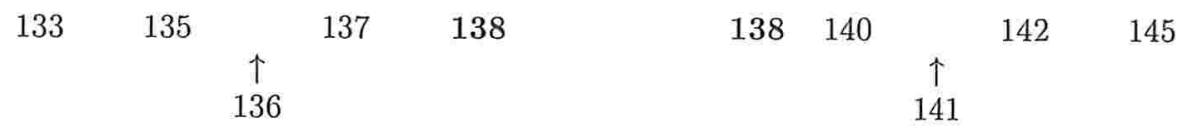

Assim, $Q_{1}=136 \mathrm{~cm}$ e $Q_{3}=141 \mathrm{~cm}$. Observa-se que nesta divisão do grupo inicial de 7 alturas, a mediana, que é uma das alturas observadas pois o conjunto tem número impar de dados, pertence aos dois subconjuntos para efeitos dos cálculos dos quartis.

Para o caso de conjuntos com número par de observações, não se considera incluir a mediana em cada um dos subconjuntos (a menos que ela coincida com valores coletados). Por exemplo, considerando 6 alturas 135, 137, 138,140,142, 145 já vimos que $Q_{2}=139 \mathrm{~cm}$ e os dois grupos teriam a seguinte configuração:

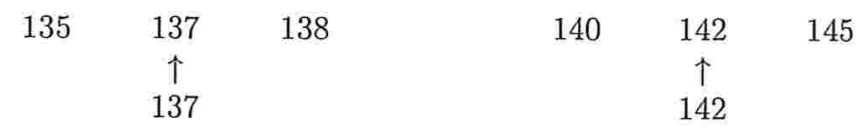

Diante disso, $Q_{1}=137 \mathrm{~cm}$ e $Q_{3}=142 \mathrm{~cm}$.

Essa escolha das divisões de grupos para calcular os quartis não é consenso e existem várias propostas para esse cálculo. Aqui estamos sugerindo uma delas deixando o leitor ciente de que é possível encontrar outras que diferem sutilmente da apresentada.

Para grandes conjuntos de dados a diferença é muito pequena e na verdade essa é a situação que mais importa. Grupos de 7 valores, como estamos usando aqui, em geral não se constituem em amostras suficientemente grandes para caracterização estatística de grupos. Assim, estamos neste primeiro momento trabalhando com valores pequenos para dirimir dúvidas quanto aos cálculos $\mathrm{e}$ oportunamente trabalharemos com grupos maiores para discutir e comparar as medidas descritivas.

\section{Variabilidade}

A variabilidade é um aspecto presente nas amostras estatísticas e motivo de estudo por parte de qualquer pessoa que entre em contato com essa área do conhecimento. Quase todas as situações são sujeitas à variações de forma, peso, volume, etc, que podem ter seus valores modificados durante a execução, tanto no dia a dia de pessoas comuns como no universo científico.

De acordo com Reading e Shaughnessy (2004), alguns currículos apresentam primeiramente as medidas de posição e de dispersão e posteriormente a isso introduzem, quando introduzem, os conceitos de variabilidade e representatividade de uma amostra, deixando uma lacuna no aprendizado. Segundo os autores, a introdução do conceito antes dos algoritmos para calcular as medidas de posição e dispersão têm mostrado resultados positivos. Nessas pesquisas os alunos são estimulados a identificar os possíveis fatores que causam variabilidade.

A variabilidade é responsável pelo desenvolvimento e sofisticação de algumas técnicas estatísticas. De acordo com Ben Zvi e Garfield (2004), esse assunto vem ganhando atenção de pesquisas recentes, no campo da educação, que envolvem o raciocínio utilizado e os processos cognitivos relacionados a compreensão da variabilidade.

O termo variabilidade se refere a uma característica de uma entidade que é observável e o termo variação está ligado à descrever ou mensurar a variabilidade de uma característica. 
Em Ben Zvi e Garfield (2004) encontramos referências sobre três tipos de comportamentos diante da variabilidadc, identificados pelos pesquisadores. Algumas pessoas simplesmente ignoram a variabilidade enquanto outras tentam encontrar padrões e tendências na variabilidade. Uma terceira postura diante da variabilidade, que mostra um pouco de conhecimento sobre o assunto, é quando se tenta controlar a variabilidade.

Uma maneira de controlar a variabilidade é elaborar um plano de coleta de dados que busque coletar os dados de maneira não tendenciosa, o que, se ocorrer, pode comprometer toda pesquisa. Nesse sentido, para controlar a variabilidade é necessário treinar a(s) pessoa(s) que vai(ão) coletar os dados. Alguns erros podem ser refletidos nas medidas de variação como os erros de registro, de medida, de transcrição e a qualidade da fonte dos dados que podem induzir a erros na coleta e interpretação de informações. Bolfarine e Bussab (2005)

Para lidar com os efeitos da variabilidade é necessário recorrer a estatísticas que mensurem a variação presente nos dados. A medida de variabilidade mais utilizada no ensino básico e divulgada pelos meios de comunicação é o desvio padrão.

Decisões tomadas em situações reais somente considerando-se a média não são confiáveis, são necessárias mais informações para viabilizar a descrição e entendimento da amostra. Podemos verificar por meio dos dados retirados de Cordani (2012) a necessidade de se considerar a variabilidade dos dados para se ter alguma ideia sobre os dados e evitar inferências tendenciosas. Vejamos uma situação que ilustra isso:

\begin{tabular}{|l|cccc|}
\hline Estabelecimento A & 0 & 0 & 0 & 100 \\
\hline Estabelecimento B & 5 & 10 & 20 & 65 \\
\hline Estabelecimento C & 0 & 0 & 50 & 50 \\
\hline Estabelecimento D & 25 & 25 & 25 & 25 \\
\hline
\end{tabular}

Tabela 2.1: Remuneração hora/aula

Observemos esse conjunto de dados como sendo a remuneração (em $\mathrm{R} \$$ ) de colaboradores por hora/aula em 4 diferentes estabelecimentos (A, B, C e D). Vemos que há trabalho voluntário em alguns casos, pois a remuneração é $\mathrm{R} \$ 0,00$, e cada estabelecimento conta com 4 colaboradores. Poderíamos motivar os alunos com a seguinte questão:

Analisando os dados das remunerações, em que estabelecimento alguém que queira receber pelo trabalho deveria se inscrever para colaborar?

As diferenças entre os salários dos quatro estabelecimentos são evidentes pela observação dos dados embora as médias dos quatro grupos sejam iguais, o que mostra que uma única medida de tendência central não basta para descrever distribuições. É correto dizer que em média a remuneração dos 4 estabelecimentos é a mesma, mas isso ajuda a melhorar a escolha do estabelecimento, tendo em vista os dados? Analisando as medianas vemos que há diferenças entre os estabelecimentos, sendo que nos casos de simetria dos dados ela coincide com a média ( $\mathrm{C}$ e D).

Observa-se a presença de variabilidade entre os valores de cada estabelecimento, sendo que somente em um deles, o $\mathrm{D}$, as remunerações não variam. É necessário informações, sobre a variabilidade para construir algum tipo de representação mais completa dos dados. A escolha sugerida acima deverá se encaminhar para estabelecimentos com alta variabilidade ou baixa variabilidade de remuneração? E como medir esta variabilidade? 
Podemos reorganizar essas medidas em uma tabela obtendo:

\begin{tabular}{|c|cc|}
\hline & média & mediana \\
\hline Estabelecimento A & 25 & 0 \\
\hline Estabelecimento B & 25 & 15 \\
\hline Estabelecimento C & 25 & 25 \\
\hline Estabelecimento D & 25 & 25 \\
\hline
\end{tabular}

Tabela 2.2: Medidas de posição

Diante dessa tabela, podemos perceber a diferença entre média e mediana quanto às suas descrições dos centros das distribuições. É possível perceber também que esses medidas não fornecem informações sobre a variabilidade dos dados. É necessário obter outras medidas que representem numericamente a variabilidade encontrada nos dados, as chamadas medidas de variabilidade.

A variabilidade é um dos aspectos que mais influenciam na incerteza inerente aos procedimentos estatísticos porém, situações reais exigem que decisões sejam tomadas e conclusões sejam feitas; sobre isso Machado (2009) escreve:

"Toda decisão implica assumir responsabilidades e correr riscos. Mas não existe opção: é tão indesejável decidir sem argumentar quanto o é argumentar sem decidir"

Nesse sentido o autor ainda menciona que o que torna mais segura uma tomada de decisão não é a inexistência do risco mas a consciência da existência do risco.

Para Batanero (2001), é nesse ponto que, considerando a variabilidade e a incerteza gerada por ela, a Estatística utiliza a probabilidade como recurso para mensurar a incerteza. Franklin et al. (2005), entendem a probabilidade como uma medida da chance de algo acontecer, ou seja, uma medida de incerteza. Baseado na probabilidade, sugere uma classificação diante das situações de incerteza que segue o seguinte padrão, de acordo com a probabilidade associada: Impossível de acontecer; Pouco provável de acontecer; Igualmente provável em acontecer ou não acontecer; Muito provável de acontecer; Certamente acontecerá.

\section{Medidas de Variabilidade}

Se todos os valores coletados forem iguais entre si, a média a mediana e a moda coincidem e seu cálculo é suficiente para resumir os dados referentes à característica de interesse. Mas essa igualdade entre os dados é praticamente impossível de acontecer em uma coleta de dados e estudar como esses dados variam dará um aporte importante para conhecer o comportamento da variável.

A medida de cálculo mais simples para medir a variabilidade (ou dispersão) de um conjunto de dados é a Amplitude que é a diferença entre o maior e o menor valor de um conjunto de dados. Assim,

Amplitude $=$ valor máximo - valor mínimo

No caso das alturas apresentadas na Figura 2.2, é fácil calcular a Amplitude que, de acordo com as informações, tem valor de $12 \mathrm{~cm}$. É claro que é uma medida imprecisa já que só utiliza dois valores do conjunto de dados, ou seja, ignora o miolo dos dados, utilizando somente os extremos. Mas para iniciar o tema variabilidade entre os alunos é o mais indicado, justamente pela simplicidade.

Por meio da Tabela 2.1 acima, podemos obter as amplitudes de cada estabelecimento e construir uma tabela mais completa com uma medida de variabilidade, no caso a amplitude, assim 


\begin{tabular}{|l|ccc|}
\hline & média & mediana & amplitude \\
\hline Estabelecimento A & 25 & 0 & 100 \\
\hline Estabelecimento B & 25 & 15 & 60 \\
\hline Estabelecimento C & 25 & 25 & 50 \\
\hline Estabelecimento D & 25 & 25 & 0 \\
\hline
\end{tabular}

Tabela 2.3: Uma medida de variabilidade

Como já mencionado, a amplitude, apesar de ser útil como primeira abordagem de variabilidade, não leva em consideração $n-2$ valores observados (sendo $n$ o número de valores observados). Uma ideia que surge então é usar todos os dados e ver como eles se comportam em relação a algum valor referência. Essa referência pode ser uma medida de posição, sendo que a mais comum é a média (poderia ser usada a mediana também).

No caso das medidas de altura, cuja média é $138,6 \mathrm{~cm}$, poderíamos medir todas as variações de cada valor de altura em relação à média. No caso das remunerações dos diferentes estabelecimentos, Tabela 2.1, seria verificar todas as variações de cada valor de remuneração em relação à média de cada estabelecimento. Para facilidade de compreensão, utilizaremos aqui este último conjunto de dados que é mais compacto.

Vamos escolher um dos estabelecimentos para sugerir os cálculos, seja C o escolhido, cujos valores de remuneração são 0050 50. Um esquema interessante e didático de apresentação da variação das remunerações do estabelecimento $\mathrm{C}$ em torno da média seria o que produz os seguintes valores de variação:

$$
(0-25) \quad(0-25) \quad(50-25) \quad(50-25)
$$

os quais somados (o que seria uma variação "total") teriam como resultado

$(-25)+(-25)+25+25=0$

É possível verificar que para qualquer dos estabelecimentos da Tabela 2.1 o resultado da variação "total" seria zero com este procedimento, o que evidentemente não representa a variabilidade dos valores de cada grupo, já que somente o estabelecimento D apresenta, de fato, uma variabilidade nula (todos os valores são iguais entre si e portanto iguais à média 25).

Assim um caminho proposto sugere elevar cada variação ao quadrado para retirar os valores negativos (outra opção seria usar o módulo).

$(-25)^{2}+(-25)^{2}+(25)^{2}+(25)^{2}=2500$.

Isso então seria uma variação total das remunerações do estabelecimento $\mathrm{C}$ que, ao ser dividida pelo número de parcelas, produz uma variação média chamada Variância.

Assim variância $=(2500 / 4)=625,00$ é uma medida de variabilidade (considerada em relação à média) cuja unidade é $(R \$)^{2}$, ou seja, o quadrado da medida original. Para voltar à mesma escala dos dados, basta extrair a raiz quadrada deste valor ( 625,00 que é a variância) e chegamos ao cálculo de Desvio Padrão. Assim obtemos o Desvio Padrão (C) é $\mathrm{R} \$ 25,00$.

Assim, organizando as medidas descritivas apresentadas em uma única tabela obtemos:

Retomando a questão inicial, que era: Em que estabelecimento alguém que queira receber pelo trabalho deveria se inscrever para colaborar?

Podemos fazer uma escolha entre quatro possiveis. Ao escolher o estabelecimento D, certamente o valor da hora/aula será de $R \$ 25,00$, pois não há variabilidade entre os salários, fato que é expresso pela amplitude 0 e pelo desvio padrão 0 . Caso seja escolhido o estabelecimento A, existe a 


\begin{tabular}{|l|ccccc|}
\hline & média & mediana & amplitude & variância & desvio padrão \\
\hline Estabelecimento A & 25 & 0 & 100 & 1875,0 & 43,3 \\
\hline Estabelecimento B & 25 & 15 & 60 & 562,5 & 23,7 \\
\hline Estabelecimento C & 25 & 25 & 50 & 625,0 & 25,0 \\
\hline Estabelecimento D & 25 & 25 & 0 & 0,0 & 0,0 \\
\hline
\end{tabular}

Tabela 2.4: Tabela completa

possibilidade do salário ser $R \$ 100,00$ por hora/aula mas também existe a possibilidade ser $R \$ 0,00$ por hora aula.

Nesse sentido podemos utilizar as medidas de variabilidade como sendo uma medida para o risco ao qual estão sujeitas as escolhas. Um alto valor para medidas de variabilidade representaria uma alta possibilidade, um alto risco, de um salário diferente do salário médio. Por outro lado, um baixo valor para medidas de variabilidade representaria um baixo risco de um salário diferente do salário médio.

De acordo com Moore (2000), as várias medidas constituem um tipo de ajuda para obter respostas e não carregam em si as respostas propriamente ditas. As decisões dependem dos critérios adotados por cada um. No exemplo acima algumas pessoas podem ser cautelosas e escolherem o estabelecimento D enquanto outras podem arriscar mais e, por isso, escolhem outro estabelecimento.

Voltando à variável altura, também podemos calcular o desvio padrão. Considerando os valores das alturas, $133,135,137,138,140,142$ e 145 e a média, $\bar{x}=138,6$, já calculada anteriormente, prosseguimos calculando a variância $S^{2}$ e em seguida o desvio padrão $S$, (usando n=7 no denominador).

$$
\begin{gathered}
S^{2}=\frac{1}{7}\left[(133-138,6)^{2}+(135-138,6)^{2}+(137-138,6)^{2}+(138-138,6)^{2}+\right. \\
\left.+(140-138,6)^{2}+(142-138,6)^{2}+(145-138,6)^{2}\right] \\
S^{2}=\frac{1}{7}\left[(-5,6)^{2}+(-3,6)^{2}+(-1,6)^{2}+(-0,6)^{2}+(1,4)^{2}+(3,4)^{2}+(6,4)^{2}\right] \\
S^{2}=14,5
\end{gathered}
$$

e como $S=\sqrt{S^{2}}$, obtemos $S=\sqrt{14,5}=3,8$.

Segundo Moore (2000), para calcular a variância é necessário um conhecimento matemático simples mas, apesar disso, seu cálculo pode ser trabalhoso e longo. Esse fator aumenta consideravelmente as possibilidades dos alunos cometerem erros no cálculo da variância além de gastarem um tempo precioso para isso. Para ensinar esse cálculo, motivando a necessidade de elevar ao quadrado e depois extrair a raiz quadrada, deve ser usado um número pequeno de valores para que o processo não fique demasiadamente longo ao aluno, com uma correspondente perda de sentido.

Assim, diante das perspectivas atuais da Educação Estatística, é aconselhável utilizar algum recurso para o cálculo da variância para que o aluno não perca o sentido do problema em meio à tantos cálculos e também para que ele tenha tempo suficiente para reflexão em sua análise dos dados. De acordo com as intenções pedagógicas do professor é possível apresentar a variância e/ou 
o desvio padrão já calculados. Em casos assim pode-se aproveitar o tempo de aula para desenvolver a análise dos dados e relacionar algumas medidas de modo a obter conclusões. Em resumo, Moore (2000) afirma que são necessárias aulas nas quais se produzem medidas e também são necessárias aulas nas quais se produzem conclusões a partir de medidas.

\subsubsection{Recursos Gráficos}

Florence Nightingale (1820 - 1910) ganhou fama como fundadora da profissão de enfermeira. Entre outros feitos, como a reforma do sistema de saúde britânico, ajudou no desenvolvimento da Estatística introduzindo uma nova maneira de apresentar dados: por meio de gráficos. Pioneira na utilização desse recurso, considerava os gráficos essenciais para entender quaisquer fenômenos sociais e os utilizava para mostrar aos seus superiores, de forma clara, os problemas que vivenciava no sistema de saúde.

Por meio do gráfico adequado é possível identificar um padrão global da distribuição, visualizando seu centro, a dispersão dos dados e alguma tendência, caso exista. Além de possibilitar uma rápida verificação da simetria, os valores discrepantes também são facilmente identificados nos dispositivos gráficos adequados.

A introdução de gráficos na escola básica, para descrever variáveis quantitativas, pode ser feita,de acordo com Brasil (1997), já no início da escolarização para estimular o quanto antes o raciocínio em termos de variação entre as observações. No início, gráficos simples como o de pontos, com dados coletados entre os alunos, são os mais indicados, já que cada um se identifica com um ponto do gráfico e este passa a fazer sentido para ele. Apesar de não apresentar diretamente as medidas descritivas, o gráfico de pontos representa os dados de modo a revelar simultaneamente características tanto individuais, pois cada elemento da amostra é representado por um ponto no gráfico quanto características coletivas, como distribuição, simetria, subgrupos e possíveis tendências. Pfannkuch e Horton (2009)

Uma das possibilidades que o gráfico de pontos oferece é que ele mostra todos os elementos da amostra ordenados e agrupados, em um eixo horizontal conforme seus valores possibilitando uma visualização global dos dados. Nesse dispositivo é possível extrair informações visuais sobre a variabilidade dos dados, sobre seus extremos, sobre padrões que se repetem, crescimento, decrescimento, ocorrências gerais e particulares, entre outras possibilidades.

A seguir temos os dados da Tabela 2.1 representados na Figura 2.3 por meio de um gráfico de pontos.

Analisando esse gráfico é possível constatar algumas cvidências já percebidas por meio da análise descritiva dos dados. Entre outras vantagens, esse tipo de gráfico possibilita uma percepção visual dos dados. Por outro lado, ao analisar somente as medidas descritivas nem sempre as distâncias entre os valores dos dados é percebida em "escala". Um salário de $\mathrm{R} \$$ 65,00 é maior que um salário de $\mathrm{R} \$ 5,00$ e isso é constatado por uma análise descritiva, porém visualizar essa diferença por meio do gráfico em escala, juntamente com os outros dados agrega, inevitavelmente, uma noção de quão distante e como estão distribuídos os valores.

\section{Gráfico de Caixas}

Pfannkuch (2006) chama a atenção para os casos nos quais a instrução da Estatística se baseia na construção de gráficos sem explicações aos alunos sobre as utilidades e vantagens de cada tipo de 


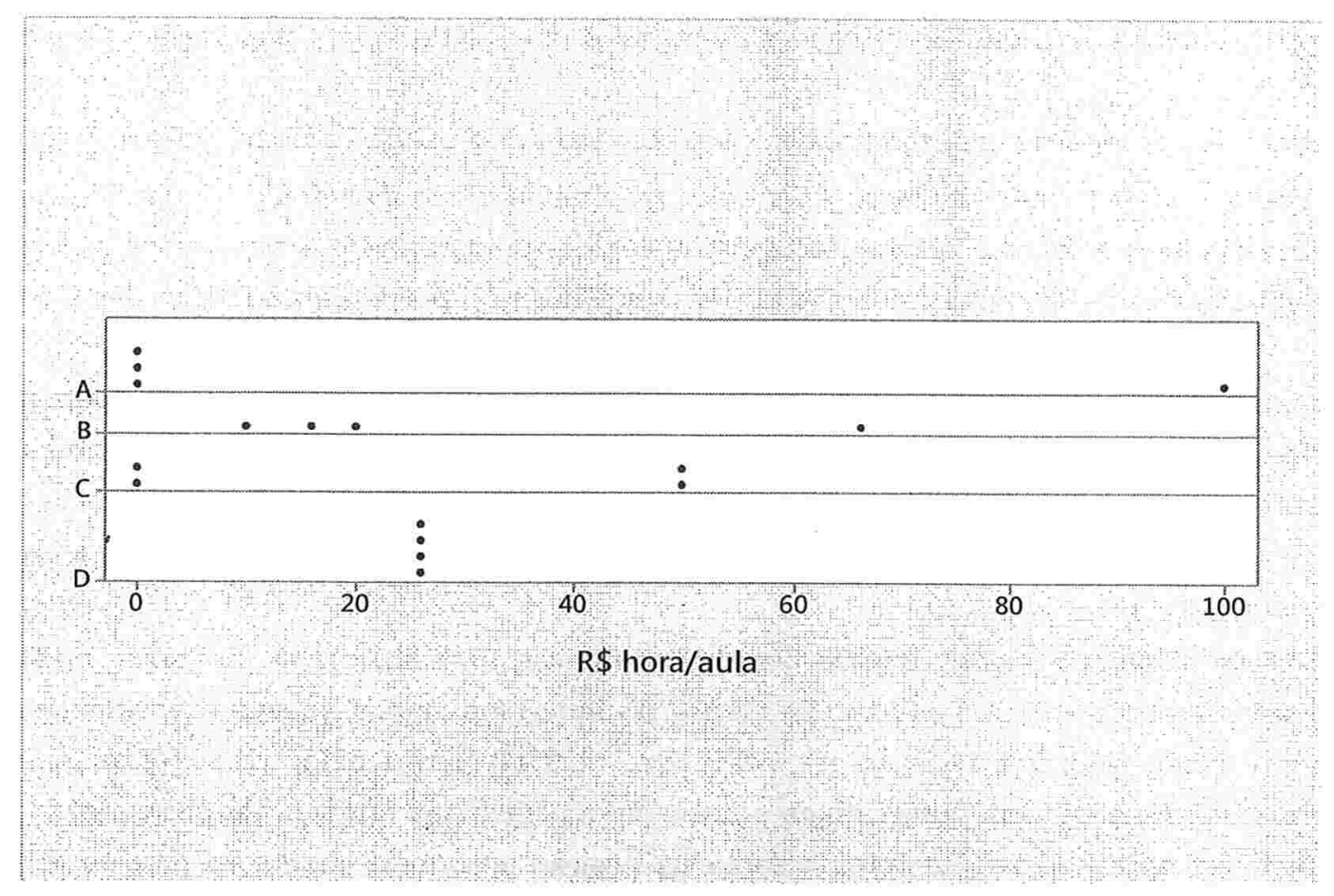

Figura 2.3: Gráfico de Pontos

gráfico. Além de saber construir um gráfico, o aluno deve saber escolher qual(is) tipo(s) de gráfico(s) utilizar em sua análise exploratória de dados.

Segundo a autora, Tukey, em 1977 desenvolveu e apresentou um dispositivo gráfico chamado box plot, ou gráfico de caixas. Esse tipo de gráfico utiliza, para sua confeç̧ão, cinco das principais medidas descritivas que são ensinadas na escola básica: o primeiro quartil, o segundo quartil ou mediana, o terceiro quartil, o máximo e o mínimo.

Moore (2000) também destaca esse tipo de gráfico e seu poder de representar razoavelmente um conjunto de dados por meio das medidas descritivas utilizadas em sua confecção, pois as cinco medidas utilizadas revelam de maneira satisfatória aspectos relacionados à posição e à dispersão dos dados. Evidentemente, para que seja útil a construção deste gráfico ć preciso um certo número de observações que justifiquem o cálculo dos quartis, por exemplo. Assim, os dados dos estabelecimentos da Tabela 2.1 que deram origem ao gráfico de pontos acima e também os 7 valores de alturas, não justificam a construção de um box plot (gráfico de caixas). Mostraremos a sua construção mais adiante, com um conjunto maior de dados.

Pfannkuch e Horton (2009) citam outras vantagens que o gráfico de caixas apresenta. Além de possibilitar uma rápida comparação visual entre as medidas descritivas, possibilita a visualização de valores discrepantes, chamados também de outliers. Por meio desse tipo de gráfico também é possível obter informações sobre a variabilidade da amostra observando a amplitude da caixa (intervalo interquartil) e a haste da caixa. Esta amplitude é igual $Q_{3}-Q_{1}$ e será denominada daqui em diante como intervalo interquartil - IQ, conforme Magalhães e Lima (2011).

Os gráficos são úteis também por permitirem comparações visuais e conclusões informais a partir 
dessas comparações visuais. Pfannkuch (2006) destaca que o gráfico de caixas e o gráfico de pontos são os tipos de gráficos que mais permitem a elaboração de conclusões sobre os dados, pois podem ser obtidos utilizando medidas descritivas elementares e possibilitar uma comparação visual entre elas.

Um dos tipos de gráficos mais difundidos é o gráfico temporal, gráfico de linha ou série temporal. Nele os dados são observados ao longo do tempo, representado em uma escala no eixo horizontal. Resultados ligados a inflação, cotações, temperaturas etc. são muito comuns na mídia e podem ser introduzidos na escola básica mediante coleta de dados dos próprios alunos ao longo das semanas de aula.

Esse dispositivo, como já mencionado, utiliza 5 medidas estratégicas (com base em dados ordenados) para compor uma caixa que descreve algumas medidas sobre a centralidade e a variabilidade de um conjunto de dados. Esse dispositivo utiliza a mediana, o primeiro e o terceiro quartis, o menor e o maior valor encontrados na amostra. Com essas medidas é composta uma caixa central com extremidades nos quartis.

Essa caixa abrange a metade interna dos dados e possui uma faixa mais destacada na forma de segmento que representa a mediana dos dados. As linhas em ambos extremos se estendem até o maior e o menor valor que estão no intervalo $\left[Q_{1}-1,5 I Q ; Q_{3}+1,5 I Q\right]$, onde $I Q=Q_{3}-Q_{1}$ é o intervalo interquartil além de eventuais pontos discrepantes que também são destacados. Esse gráfico pode ser apresentado tanto com a caixa na posição horizontal quanto na posição vertical sempre utilizando uma escala numérica.

Para analisar duas amostras sob a mesma variável e na mesma escala representadas por um gráfico de caixas, é aconselhável plotar os dois gráficos em um mesmo sistemas de eixo e comparar os elementos correspondentes que se encontram em cada uma das caixas. O gráfico de caixas sumariza algumas informações e incorpora em sua disposição noções como as de mediana e de quartis que são conceitos de difícil entendimento por muitos alunos.

Por meio das medidas descritivas utilizadas na elaboração do box plot (gráfico de caixas) é possível desenvolver uma parte do raciocínio de Inferência Informal necessário para comparar dois grupos. De acordo com Pfannkuch (2006), o ensino desse dispositivo gráfico poderoso, que sumariza medidas estratégicas, não está presente em todos os países. No Brasil dificilmente esse tipo de gráfico é encontrado nos livros didáticos. É comum um aluno completar o ensino médio sem nunca ter visto esse tipo de gráfico. Segundo a mesma autora, nos Estados Unidos o ensino do gráfico de caixas é recomendado a partir dos 12 anos.

Como já foi exposto anteriormente, pesquisas revelaram que muitos alunos sabem calcular medidas mas não conseguem usá-las para caracterizar e descrever o conjunto de dados com o qual estão trabalhando. A vantagem do gráfico em questão é que ele fornece uma noção intuitiva da função das medidas que caracterizam, e auxiliam a descrever, um conjunto de dados. Essa facilidade está ligada a disposição visual dos elementos que compõem o gráfico.

O gráfico de caixas também pode ser interpretado como um sinal (medida de posição) e um ruído (espalhamento dos dados). Ele revela a posição das informações, o espalhamento dos dados a partir da mediana, a densidade dos dados, os valores extremos dentro dos limites do intervalo e fora do intervalo, os valores discrepantes. Segundo Konold e Pollatsek (2002), com esse dispositivo é possível obter informações sobre um grupo em sí ou comparar dois grupos de uma maneira visual, comparando a disposição da caixa em um sistema de eixo coordenados. A utilização desse tipo de 
gráfico tem se revelado um elemento poderoso no sentido de promover o entendimento dos conceitos e medidas que o compõem.

Mesmo diante das vantagens apresentadas, o professor precisa auxiliar as generalizações realizadas pelos alunos. Em uma de suas pesquisas, Pfannkuch (2006) alerta para a grande quantidade de erros iniciais cometidos pelos alunos ao comparar medidas não equivalentes entre os gráficos. A pesquisadora chama a atenção para os ganlıos que o gráfico de caixas proporciona quando os alunos adquirem habilidades de comparar os centros, a distribuição dos dados e os efeitos do tamanho da amostra para fazer inferências informais e a facilidade que estes têm de assimilar os procedimentos formais de inferência. Em outras palavras, o desenvolvimento do raciocínio estatístico, por meio de uma abordagem informal com o auxílio desse tipo de gráfico, torna mais fácil o entendimento dos procedimentos formais de inferência.

Assim, esse recurso visual pode ser utilizado em diferentes níveis de aprendizado e explorado de acordo com o entendimento dos alunos com argumentos e relações cada vez mais sofisticados Watkins et al. (2001) Nesse mesmo sentido, Machado (2009) evidencia que um mesmo objetivo pode ser atingido em diversos níveis de profundidade e com a mesma seriedade.

Os valores interquartis são vistos como um sinal que está ligado à centralidade dos dados. As caixas representam $50 \%$ dos dados centrais tais que seus valores estão entre $Q_{1}$ e $Q_{3}$. O espalhamento dos dados, ou seja, a forma como estão dispostos é um fator que revela a variabilidade dos dados. Olhar os valores dos pontos de corte na extremidade da haste da caixa dos dados também ajuda a perceber a variabilidade presente nos dados.

Além das características não determinísticas e da incerteza que permeiam as ideias da Estatística e a diferencia da Matemática, atribuir significados aos dados é uma parte da Estatística que necessita da participação ativa do aluno. É necessário que, além da pequena história sobre o contexto no qual os dados estão inseridos, os alunos utilizem seus conhecimentos acumulados para apoiar o trabalho com os dados, mesmo que esses conhecimentos acumulados tenham sido adquiridos momentos antes, durante a discussão sobre o tema e a elaboração de uma pergunta. É importante que o aluno agregue o máximo de informação que puder para concluir sobre as várias representações dos dados.

A quantidade de evidências que um aluno consegue enxergar e descrever bem como a quantidade de elementos que consegue relacionar para obter evidências que justifiquem as inferências feitas, dependem do conhecimento do aluno e não da sua idade propriamente dita. Assim espera-se que alunos mais experientes apresentem uma maior quantidade de evidências estatísticas bem como um vocabulário com termos estatísticos ligados às ideias poderosas e fundamentais da Estatística.

A Figura 2.4, adaptada de Magalhães e Lima (2011), mostra a estrutura de um gráfico de caixas, com base nas medidas descritivas. 


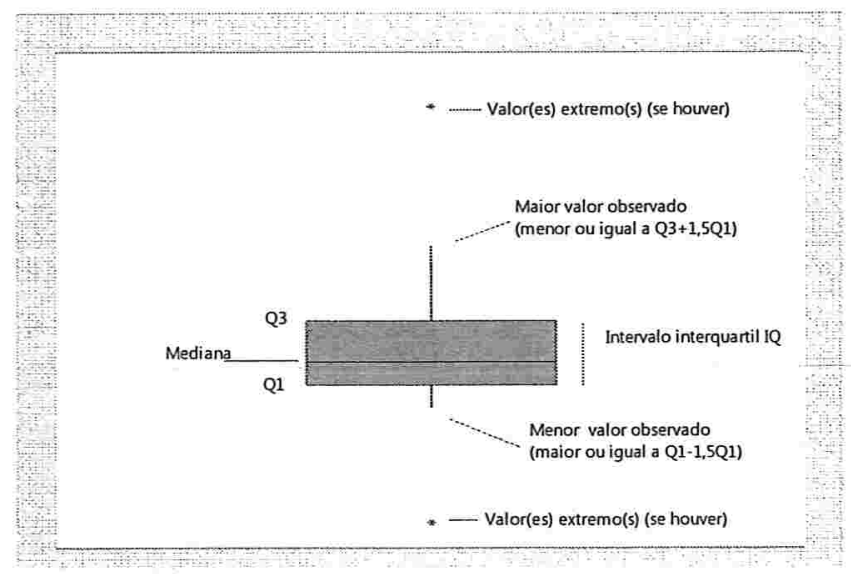

Figura 2.4: Estrutura de um Bòx Plot (Gráfico de Caixas) 


\section{Capítulo 3}

\section{Educação Estatística}

Assim como a sociedade de modo geral, a Educação Estatística está passando por mudanças e adequações. Essas mudanças são motivadas pelo surgimento de novas demandas de profissionais e cidadãos que necessitam de novos saberes, antes não ensinados nas instituições de ensino. Alguns novos saberes não são tão novos assim na história da humanidade mas novos nas salas de aula; é o caso da Estatística, que busca atender essas demandas por meio da Educação Estatística.

Um marco nesse campo é a criação, em 1991, da IASE - International Association for Statistical Education ) uma seção do ISI - International Statistical Institute, que inicia suas atividades tendo entre seus principais objetivos promover o entendimento e o avanço da Educação Estatística e de assuntos correlacionados.

Os conhecimentos relacionados a esse tema apareceram recentemente nos currículos e diretrizes de diversos países e somente poucas décadas atrás surgiram as primeiras pesquisas relacionadas a ele.

Para Batanero (2001) os conteúdos que abrangem a Análise e Exploração de dados e a Inferência Estatística ainda são pouco explorados. Isso pode ocorrer ou porque os professores priorizam alguns conteúdos matemáticos que julgam mais relevantes, ou porque os professores têm predileção por outros assuntos, ou ainda porque os professores têm pouca afinidade nessa área.

Fiorentini e Lorenzato (2006) relatam que, no Brasil, nos anos 90, houve uma grande movimentação de educadores que regressaram de diversos países após obterem formação fora do Brasil. Após esse período um grande número ainda maior de educadores concluiu cursos de pós graduação ligados a diversas áreas.

Severino (2007) relata posturas pedagógicas com atividades menos forçadas e maçantes para os alunos, onde o aprendizado ocorre de maneira mais espontânea e menos mecanizada. Para que isso ocorra são necessários material de trabalho específico e pessoal para explorá-lo adequadamente.

Diante disso, um novo olhar sobre a Estatística conquistou espaço nos currículos escolares da escola básica em diversos países, inclusive no Brasil. Assim, as orientações curriculares do Brasil e desses outros países são elaboradas para que os alunos do ensino básico adquiram um conhecimento básico em Estatística.

Descartar o que não é essencial e memorizar o que é relevante não é suficiente para transformar informação em conhecimento: essa passagem é um tanto misteriosa e envolve um toque de pessoalidade inexplicável.

Conforme apresentado por Campos et al. (2011) ao longo de sua obra, entre outras contribuições para compreender fenômenos de outras áreas, a Educação Estatística contribui também para 
a formação de um sujeito globalizado com responsabilidade ambiental incentivando uma postura crítica c reflexiva diantc das informações disponíveis. Transformar dados em informações e interpretar dados relacionados a problemáticas do cotidiano podem conduzir à percepção de aspectos antes desapercebidos como as origens das desigualdades na quais estão imersas a boa parte dos estudantes. Apoiados em conceitos estatísticos é possível o desenvolvimento das habilidades ligadas a análise exploratória de dados, inferência e a tomada de decisões em situações de incerteza.

Para uma formação completa, busca-se mostrar aos alunos as partes e também o todo de um processo de investigação estatística, aprimorando o desenvolvimento de habilidades interpretativas, para argumentar, refletir e criticar empregando adequadamente as terminologias para comunicar ou justificar afirmações estatísticas. Ben Zvi e Garfield (2004)

Atualmente, dentre os novos papeis que o professor exerce em uma escola, cabe também a eles preparar os alunos para uma vida plena fora da escola, transmitindo cultura e valores, não apenas visando um futuro profissional fora da escola.

Diante do novo olhar proposto, a Educação Estatística, se mostra repleta de possibilidades podendo ser muito bem aproveitada por alunos e professores. Ela permite uma abordagem problematizadora pois utiliza dados reais que conectam os alunos à realidade que vivem, tornando-os indivíduos que participam do mundo ao invés de apenas o assistirem mudar.

De acordo com Machado (2013), em diversos momentos nos deparamos com alguma situação de caráter aleatório. Se hoje vai furar o pneu, se haverá alguma interrupção no fornecimento de energia elétrica, se vamos encontrar um conhecido no supermercado, a previsão do tempo, cotações da Bolsa, entre outros acontecimento, são regidos pelo acaso. Diante disso, a Estatística é um recurso para lidar com situações nas quais existe o acaso. Para o autor, na escola básica, a Estatística ocupa uma posição muito menos destacada do que aquela que sua importância teórica deveria determinar.

Devido a algumas estratégias educacionais presentes, algumas aulas podem se transformar em penosos momentos de cálculo de medidas como média, desvio padrão etc. Abordagens desse tipo gera alunos que acabam por memorizar os algoritmos, calculam as medidas e depois não sabem interpretá-las ou relacioná-las com outras medidas para tirar conclusões plausíveis e, em alguns casos, nem mesmo conseguem utilizar as medidas descritivas para caracterizar ou descrever os dados.

De acordo com Brousseau (2008), "... os algoritmos, fora de um contexto, tornam-se resposta adquiridas para futuras perguntas sobre as quais ainda não se sabe muita coisa."

\subsection{Crescimento do Interesse e da Necessidade da Estatística}

Os conhecimentos ligados a Estatística, associados aos aspectos individuais de cada aluno, permitem um leitura do mundo feita por meio dos dados estatísticos. Nesse sentido, Moore (2000) compara o letramento alfabético, ou seja, saber ler, escrever e entender o que se está lendo com letramento estatístico.

As palavras que não interpretam a si mesmas, devem ser lidas com entendimento. Quando desorganizadas, as palavras formam frases sem sentido, às vezes com sentido mas sem entendimento. $O$ mesmo acontece com os dados. Quando desorganizados tornam-se sem sentido. Para interpretá-los é necessário entendimento da Estatística, mais especificamente do letramento estatí́stico. Conforme Campos et al. (2011) sem esse conhecimento mesmo dados organizados podem se tornar dados inex- 
pressivos, enganosos, desconexos ou sem sentido. Quando organizados, relacionados e comparados adequadamente podem revelar informações e tendências antes desapercebidas.

Ben Zvi e Garfield (2004) e Moore (2000) também chamam atenção para a crescente importância da Estatística bem como sua indispensável função na compreensão de fenômenos diversos que envolvem diversas situações no mundo, repletas de informações de natureza quantitativa. Destacam também a crescente necessidade dos cidadãos e profissionais possuírem conhecimentos estatísticos e a crescente importância da Estatística no cenário educacional mundial.

A passagem da parte para o todo, ou seja, da amostra para a população, que caracteriza a Inferência Estatística, chama a atenção de muitos pesquisadores não só pela sua relevância como também pelas dificuldades, relatadas por professores, em compreender alguns conceitos.

Sotos et al. (2007) identificam três fatores que despertam interesse de pesquisadores sobre esse tema. O primeiro é o fato da Estatística ser um dos tópicos de principal relevância largamente utilizado pelas ciências empíricas. O segundo é que a Inferência Estatística, é um dos principais instrumentos para se lidar com situações de incerteza. Em terceiro, muitas pessoas, ao utilizarem os fundamentos da Estatística, são susceptíveis a erros, talvez por exigirem um certo grau de abstração e apresentarem uma complexa conexão com a realidade.

Devido à equiparação equivocada que algumas pessoas fazem ao relacionar a Estatística e a Matemática, Ben Zvi e Garfield (2004) comentam sobre a necessidade de reformular os livros didáticos que acabam por transformar as aulas de Estatística em uma sucessão de cálculos mecanizados por meio da aplicação de fórmulas, induzindo o determinismo quando deveriam desenvolver justamente o oposto.

\subsection{Necessidades Estatísticas de um Cidadão}

A preocupação com as habilidades estatísticas de um cidadão é um assunto discutido há um certo tempo em diversos cenários como empresarial, governamental e educacional.

Campbell (1974), já manifestava em sua obra os perigos da ignorância Estatística, escrevendo um capítulo exclusivo sobre o assunto, no qual podemos destacar as advertências do autor sobre a crescente necessidade da utilização dos conhecimentos estatísticos de um cidadão. Inclusive o autor alerta sobre a necessidade de em um tempo futuro no qual a utilização diária dos conhecimentos estatísticos serão indispensáveis para o exercício da cidadania.

De acordo com Brasil (1997), o ensino fundamental deve ser voltado também para a aquisição de competências básicas necessárias ao cidadão e não apenas voltadas para a preparação de estudos posteriores. Os PCN's, como são chamados, norteiam seus parâmetros observando a formação básica do cidadão brasileiro. Falar em formação básica para a cidadania significa falar da inserção das pessoas no mundo do trabalho, das relações sociais e da cultura, no âmbito da sociedade brasileira.

Ainda em Brasil (1997) encontramos o seguinte trecho:

"A compreensão e a tomada de decisões diante de questões políticas e sociais também dependem da leitura e interpretação de informações complexas, muitas vezes contraditórias, que incluem dados estatísticos e índices divulgados pelos meios de comunicação. Ou seja, para exercer a cidadania, é necessário saber calcular, medir, raciocinar, argumentar, tratar informações estatisticamente, etc. Da mesma forma, a sobrevivência numa sociedade que, a cada dia, torna-se mais complexa, exigindo novos padrões de produtividade, depende cada vez mais de conhecimento." 
Diante disso percebe-se que mudanças na Educação Estatística estão ocorrendo no sentido de proporcionar aos alunos condições para que exerçam cidadania e também compreendam melhor onde vivem.

\subsection{Diferenças e Semelhanças entre Matemática e Estatística}

De acordo com Campos (2007), a organização curricular atual propõe uma estrutura onde a Estatística parece ser uma parte da Matemática. Isso transmite para muitos a falsa ideia de que ambas as disciplinas teriam um desenvolvimento didático/pedagógico muito semelhante. De fato, existem semelhanças entre elas porém, alguns aspectos são inerentes apenas à Estatística e, por isso, exigem um estudo didático ajustado uma vez que não dizem respeito à Matemática.

Batanero (2001), ao mencionar que a Estatística atravessa um período de notável crescimento, com cada vez mais procedimentos disponíveis, ressalta algumas das diferenças entre a Matemática e o que ela denomina de "ciência dos dados". A Estatística, bem como a didática envolvendo seu ensino, apresenta uma natureza aleatória, oposta ao determinismo da Matemática. Em outras palavras, na Estatística o acaso e a incerteza estão sempre presentes enquanto que na Matemática não.

Assim como outras áreas do conhecimento, a Estatística utiliza algumas ferramentas da Matemática, mas é diferente desta: a Estatística busca extrair informações de dados, quantitativos (numéricos) e qualitativos (não numéricos), e não apenas manipulá-los.

Nesse sentido, Moore (2000) os tipos de dados estatísticos de natureza quantitativa se distinguem dos números porque não são números propriamente ditos. Eles trazem junto com seu valor numérico informações adicionais reveladas pelo contexto no qual estão inseridos. Assim, os dados, o contexto e os conhecimentos gerais de quem manipula os dados se traduzem em informações compondo um cenário e imprimindo significados que extrapolam os números.

Em outras palavras, os objetos estudados pela Estatística são distintos dos objetos estudados pela. Matemática.

Diante disso, Moore (2000) afirma que a Estatística é formada pela união de uma estrutura lógica com o empirismo, fortalecido pelas experiências entre o aleatório e o determinístico.

Um dos motivos que endossam a falsa crença de que a Estatística é parte de Matemática é o fato de ainda ser comum encontrar livros que tratam a Estatística como uma parte ou área da Matemática, talvez por seguirem a organização proposta em Brasil (1997).

Ben Zvi e Garfield (2004) chamam a atenção pare esse fato, pois em outros países esse modelo se repete em livros didáticos que dispõem, resumidamente, os conteúdos estatísticos inseridos como parte de livros de Matemática, principalmente livros do ensino básico.

Diante disso alguns profissionais, seguindo de perto os roteiros desses livros, enfatizam cálculos e mecanização nas aulas de Estatística, fazendo das aulas de Estatística mais Matemática do que deveria ser.

Campos (2007) destaca algumas características da Estatística tais como a aleatoriedade e incerteza. Realizar experimentos, coletar dados, organizá-los, analisá-los considerando a influência da variabilidade na experiência que se tem para perceber os desdobramentos desse assunto, tomar uma decisão considerando a incerteza de um fenômeno são ações que contêm uma parte subjetiva que pode ser contraposta ao determinismo da Matemática 
Para Severino (2007), os termos linguísticos também ajudam a caracterizar as áreas distintas do conhecimento. A presença de termos próprios reflete a existências de ideias próprias, ausentes em outras áreas. Como exemplo desses termos podemos destacar: desvio padrão, distribuição amostral, dados, variabilidade, Inferência Formal, amostra, medidas descritivas, entre outros. Esses termos não remetem somente a ideias mas também a conceitos ou técnicas e, ao serem utilizados, facilitam a comunicação escrita e verbal entre os que utilizam a Estatística de alguma forma.

\subsection{Tratamento da Informação e Análise Exploratória de Dados}

De acordo com Brasil (1997), o tratamento de informação integra os estudos relativos às noções básicas de Estatística, Probabilidade e Combinatória. Conforme citado por outros autores, esse documento também destaca a crescente importância do tratamento da informação e o classifica como um bloco de conteúdos.

Quanto ao que denomina "Tratamento da Informação", Brasil (1997) elenca as habilidades relacionadas a: leitura e interpretação de informações contidas em imagens; coleta e organização e descrição de dados; interpretação e elaboração de listas, tabelas simples, de dupla entrada e gráficos de barra para comunicar a informação obtida; produção de textos escritos a partir da leitura e interpretação de listas, tabelas, diagramas e gráficos. Identificação de características previsíveis ou aleatórias de acontecimentos; entre outras tantas habilidades .

\subsection{Componentes da Educação Estatística}

Quando educadores estatísticos discutem recomendações sobre as reformas no ensino da Estatística muitas vezes utilizam os termos letramento estatístico, raciocínio estatístico e pensamento estatístico porém, nem sempre esses termos possuem definições idênticas, variando um pouco de autor para autor. Assim, diferenças e similaridades entre os significados e as características que os compõem estão atreladas, sendo muitas vezes dependentes umas das outras e se misturam, sucedendo relações de causa e consequência.

Embora não haja uma definição formal desses três termos, existe uma certa convergência entre alguns pesquisadores sobre as características de cada um. Ben Zvi e Garfield (2004) se referem ao letramento estatístico destacando seus principais aspectos que incluem as habilidades básicas que são usadas para entender informações e resultados estatísticos.

Apresentaremos a seguir as três terminologias seguindo alguns autores.

\section{Letramento Estatístico}

Organizar dados, construir tabelas, trabalhar com diferentes representações dos dados, entender os conceitos, desenvolver vocabulário, compreender os símbolos e utilizar a probabilidade como uma medida de incerteza também são componentes do letramento estatístico. Em termos de vocabulário, ou seja, conjunto de termos e palavras, existem níveis.

De acordo com Severino (2007), o primeiro nível é o vocabulário comum, usado na comunicação social e não é adaptado à vida científica. O conhecimento científico necessita de um segundo nível de vocabulário, ou seja, um vocabulário técnico. 
Assim como ocorre nos demais segmentos científicos, a Estatística possui conceitos específicos que exigem tcrmos com significado único c bcm delimitado. Dessa maneira, utilizar esses termos corretamente demonstra familiaridade com as ideias e significados associados e demostram a compreensão dos mesmos.

Para alguns autores, como Ben Zvi e Garfield (2004), delMas (2002) e Campos (2007), o termo letramento ou literacia se relaciona com outras habilidades além das relacionadas à linguagem e o emprego dos termos específicos, estendendo-se à habilidades básicas tais como as utilizadas para analisar dados e relacioná-los com ideias gerais, termos, símbolos e outros componentes das teorias estatísticas. (Severino (2007) destaca que, independentemente da área do conhecimento, o emprego correto de palavras chaves são os sinais do entendimento dos conceitos.)

Campos (2007), considera a literacia, do ponto de vista da Educação Estatística, contendo a habilidade de argumentar. Para desenvolver essa habilidade é necessário empregar terminologia estatística, além disso, interpretar e avaliar criticamente as informações estatísticas.

O letramento estatístico, de acordo com Campos (2007), também engloba habilidades envolvidas na compreensão de textos relacionados à Estatística bem como de relatórios de pesquisas estatísticas. Outro aspecto do desenvolvimento do letramento estatístico é a utilização da Estatística para sustentar argumentos encontrados em situações vivenciadas pelos alunos.

Em Brasil (1997), para ser considerado alfabetizado pressupõe "saber ler e interpretar dados apresentados de maneira organizada construir representações, para formular e resolver problemas que impliquem o recolhimento de dados e a análise de informações."

\section{Raciocínio Estatístico}

De maneira geral, Severino (2007) destaca que "o raciocínio é, pois, um dos elementos mais importantes da argumentação, porque suas conclusões fornecem bases sólidas para os argumentos." Assim, os novos conhecimentos chegam por meio de um processo lógico do pensamento que reorganiza os conhecimentos acumulados.

Para o autor, é por meio do raciocínio que ocorre o amadurecimento do pensamento.

Ben Zvi e Garfield (2004) definem raciocínio estatístico como sendo a maneira com que as pessoas articulam as ideias e interpretam as informações estatísticas, conjunto de dados, representações gráficas dos dados e os sumários. O raciocínio estatístico envolve também a maneira como são conectados os conceitos e encadeadas as ideias. Além disso, a capacidade de entender e explicar os processos estatísticos bem como interpretar resultados são características que devem pertencer às pessoas com o raciocínio estatístico desenvolvido.

Para Harradine et al. (2011) o raciocínio estatístico é o processo em que as pessoas usam a razão e as ideias estatísticas para fazerem afirmações com sentido e coerência. Nesse processo são utilizados conceitos, principalmente os relacionados a distribuição, centralidade, variabilidade, incerteza, aleatoriedade, amostra, entre outros. Os autores destacam que desenvolver o raciocínio, ou seja, as habilidades de articular corretamente os conceitos estatísticos, é a principal dificuldade relacionada à Inferência Estatística.

Em Gal et al. (1989) e Garfield (2002) podemos encontrar uma classificação tanto para os níveis de raciocínio quanto para os tipos de raciocínio que estes autores identificaram em suas pesquisas. Eles recomendam que um pleno desenvolvimento do Raciocínio Estatístico seja dado por meio de abordagens utilizando dados reais, tecnologia e participação ativa dos alunos, ou seja, estes devem 
pessoalmente fazer learning by doing, ou seja, aprender fazendo.

Para Campos (2007), o raciocínio estatístico se manifesta de diversas formas. Raciocinar sobre os dados e sua representação, raciocínio sobre as medidas descritivas e a incerteza é necessário para construir e desenvolver relações entre dados e o problema. Dessa maneira, o raciocínio auxilia na interpretação dos dados no julgamento de informações envolvidas em um problema.

\section{Pensamento Estatístico}

O pensamento estatístico envolve o entendimento dos motivos e maneiras que direcionam as investigações estatísticas e envolve também o entendimento das ideias poderosas que estão por detrás dos processos investigativos. Entre as ideias poderosas podemos destacar a variação e as medidas descritivas, que resumem os dados tanto numericamente quanto em gráficos. O pensamento estatístico envolve também a compreensão da natureza e representatividade de uma amostra, quando e como aplicar os processos e utilizar a ferramenta inferencial adequada.

Ainda são atribuídos ao pensamento estatístico o entendimento dos modelos matemáticos e das simulações de fenômenos feitas a partir desses modelos, como são realizadas as coletas e produção de dados que visam calcular probabilidades e a utilização do contexto para interpretar os dados e elaborar conclusões. Em outras palavras, Ben Zvi e Garfield (2004) afirmam que pensadores estatísticos são aptos a criticar, avaliar e entender o processo completo que envolve o estudo da Estatística e a solução de problemas.

O pensamento estatístico também está ligado a capacidade de relacionar os dados com situações reais, considerando a aleatoriedade e a variabilidade envolvidas para extrair informações neles contidas. A compreensão das etapas do processo Estatístico e suas inter-relações, o entendimento de suas interações e significados, e habilidades para lidar com questões particulares que, às vezes, vão além do que encontramos na literatura são também habilidades que um professor deve considerar quando se pretende desenvolver pensamento estatístico.

Para Campos (2007), o pensamento estatístico esta representado pela capacidade de relacionar dados com situações concretas. Por meio dessa componente é possível compreender sobre o que os dados dizem sobre o problema. Esse aspecto é percebido quando o aluno desenvolve reflexões seja por partes de um processo ou por completo.

Quando arquitetamos maneiras de relacionar dados e conseguir informações destes também estamos desenvolvendo o pensamento. Assim, é possível notar não só aspectos distintos entre letramento estatístico, o raciocínio estatístico e o pensamento estatístico como também aspectos comuns entre eles. Esses termos por vezes se misturam e, por isso, não há uma distinção consensual entre eles.

Tanto é assim que delMas (2002) propõe dois modelos mostrando duas possibilidades quanto às relações entre esses componentes. O primeiro mostrando cada um deles contendo uma parte distinta, exclusiva e outras partes comuns com os demais componentes. O segundo modelo apresenta o raciocínio estatístico e o pensamento estatístico como partes contidas em uma conjunto maior, no caso literacia estatística. 


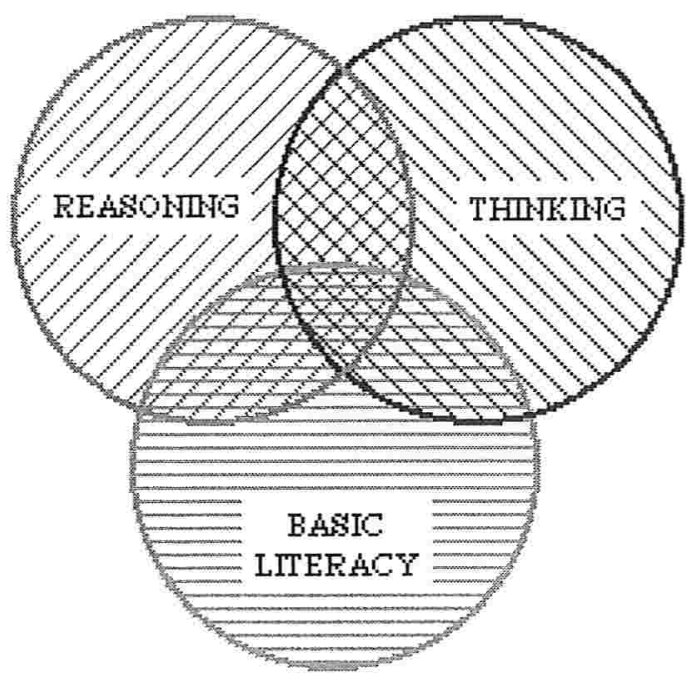

Figura 3.1: Modelo 1

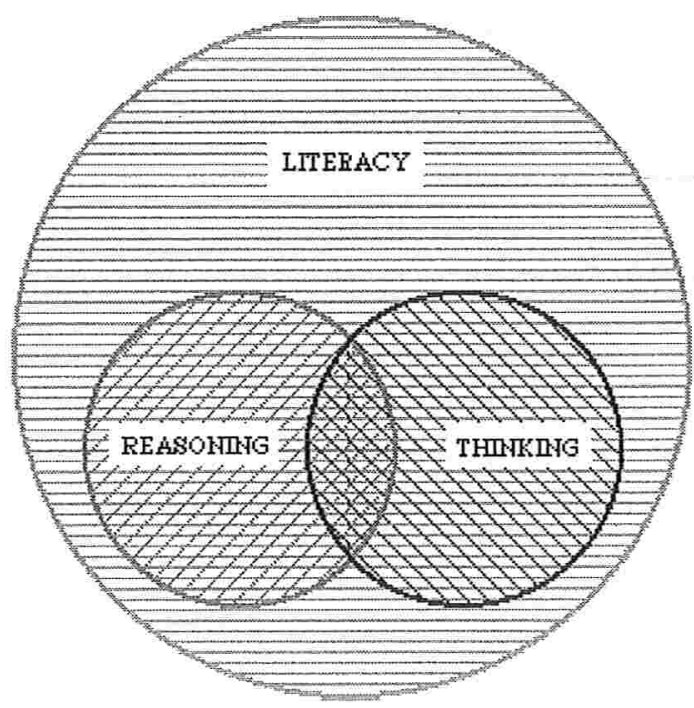

Figura 3.2: Modelo 2 


\section{Capítulo 4}

\section{Educação Estatística - Algumas Dificuldades}

Estamos caminhando para uma sociedade cada vez mais informatizada a e a compreensão das técnicas básicas de análise exploratória de dados e sua interpretação adequada são cada dia mais importantes. De acordo com Batanero (2001), uma das maiores dificuldades enfrentadas é a diferença entre o conhecimento apresentado pelos alunos de uma mesma classe, sendo necessário aos professores trabalhar com diferentes capacidades.

Além disso existe uma dificuldade inerente a se ensinar um tema em contínua mudança e crescimento.

Segundo Pfannkuch (2006), na primeira década deste século, o entendimento dos conceitos estatísticos básicos e o raciocínio inferencial, que acompanha muitos procedimentos estatísticos, foram destacados como sendo áreas problemáticas do ensino de estatística.

De acordo com Brasil (1997), assim como o conhecimento matemático o conhecimento estatístico formalizado precisa, necessariamente, ser transformado para se tornar passível de ser ensinado/aprendido. Esse processo de transformação do saber científico em saber escolar não passa apenas por mudanças de natureza epistemológica, mas é influenciado por condições de ordem social e cultural que resultam na elaboração de saberes intermediários, como aproximações provisórias, necessárias. e intelectualmente formadoras.

\subsection{Atuação do Professor}

Muito se fala sobre a atuação dos professores nas escolas e sobre os diversos segmentos sociais que se preocupam com a educação de seus sucessores.

Segundo Fiorentini e Nacarato (2005), em toda história nunca houve tantos professores quantos os que atuam hoje na escola. Esse número é resultado da pressão decorrente do desenvolvimento das tecnologias ligadas à informação juntamente com as rápidas transformações culturais e sociais que acompanham essa acelerada mudança. Diante disso o professor é obrigado a reaprender e ensinar de modo diferente do que lhe foi ensinado.

Para Hogg e Tanis (2001) a desvalorização profissional do professor também é umi dos motivos que atualmente dificulta o entendimento dos conceitos. Percebe-se poucas mudanças nos textos elementares de ano pra ano, forçando o professor a ensinar os mesmos conteúdos da mesma maneira. 
Essa tendência a repetir as aulas da mesma maneira pode gerar lacunas na compreensão dos assuntos necessários, pois estes encontram-se em um momento de progresso rápido.

Os autores ainda chamam a atenção para o fato de alguns professores desenvolverem muitas aulas que apenas trabalham tradicionalmente a leitura e a discussão. A Estatística oferece diversas possibilidades de ensino, individuais e em grupos de acordo com as possibilidade do professor. A ausência de simulações, experimentos e projetos também é uma falha cometida por professores que poderia ser evitada facilmente com a incorporação dessas práticas nas aulas o que certamente aumentaria as possibilidades de sucesso das aulas.

Outro aspecto dependente da atuação do professor é o planejamento das aulas. Quando o professor considera apenas suas intenções sem ponderar as intenções dos estudantes bem como suas características atuais e tendências futuras, ele corre o risco de ensinar coisas que serão pouco compreendidas e utilizadas. Além disso a falta de um domínio suficiente sobre um assunto pode comprometer o sucesso na aplicação de algumas técnicas e desenvolver nos alunos uma antipatia pelo assunto.

Mesmo em classes numerosas é necessária alguma interação entre o professor e os alunos. Para Hogg e Tanis (2001), é possível reservar alguns minutos e selecionar alguns alunos para relatarem os pontos mais importantes da aula, abrir espaço para eles manifestarem suas dúvidas e opiniões mesmo que sejam manifestadas por meio escrito ou que sejam trabalhadas em aulas futuras.

Para Machado (2010), a enfatização ou supressão de certos elementos pode conduzir a uma deformação intencional dos novos objetos criados por meio da dicotômica composição/decomposição do que existe e do que é novo. Além disso, a ordenação do conhecimento adquirido com uma narrativa introduz temporalidade e possibilita a fixação de novas ideias.

De acordo com Melo (2005), a formação dos professores é vinculada com o currículo que, diante de inovações curriculares, necessitam desenvolverem novas habilidades, competências, atitudes, etc., ampliando assim os saberes docentes.

\subsection{Excesso de Matemática e Mecanização de Procedimentos}

Como exposto na seção 3.3, frequentemente a Estatística é equivocadamente apresentada como um ramo da Matemática e pior, é desenvolvida como se fosse um ramo da Matemática. Assim, existem diferenças e também uma interdependência entre elas ainda, o que confunde alguns profissionais. Diante disso é comum, no início da aprendizagem, abordagens que carregam o rigor e a formalidade da Matemática que ofuscam as particularidades da Estatística e dificultam sua compreensão. De acordo com Hogg e Tanis (2001), esse tipo de excesso pode ser percebido, entre outras evidências, pelo uso desnecessário de notações.

Estudantes tendem inicialmente a confiar mais em fórmulas do que nos próprios pensamentos. É necessário um trabalho para que eles desenvolvam a capacidade de argumentar valorizando as opiniões e argumentos frente a algoritmização em algumas situações, desenvolvendo um trabalho que destaque as ideias e as análises ao longo do processo em vez de focar no modelo teórico da situação.

A Estatística vai muito além dos procedimentos de cálculos, não faz sentido esgotar a exploração da Estatística elencando um conteúdo prioritário da disciplina focado no preenchimento de tabelas e números descontextualizados na ânsia de ensinar conceitos. Essa maneira de trabalhar deixa de 
lado um processo que envolve diversas aprendizagens.

O tempo que os alunos gastam calculando medidas resumo, sem dúvida, poderia ser gasto para refletir sobre os significados dos conceitos. Hogg e Tanis (2001) defendem que, em algum momento, é necessário que os alunos calculem, eles próprios, essas medidas. Geralmente essa exigência é feita quando se tem um número reduzido de dados a fim de auxiliar no entendimento dos conceitos, e não de ocultá-los sob muitas contas.

Algumas técnicas são ensinadas isoladamente, sem conexão com o real. Isso pode tornar o aprendizado desestimulante. Diante de aulas carregadas de procedimentos, alguns alunos não percebem imediatamente uma aplicação da Estatística em seus cotidianos e acabam por considerar a Estatística de pouca ou nenhuma utilidade. Dessa maneira podem perder o interesse pela matéria. Sobre as aplicações da Estatística é preciso uma reflexão que considere as características dos alunos para que não sejam apresentadas situações artificiais c perceptivelmente forçadas, pois podem ser igualmente desestimulantes.

\subsection{Abstração e Linguagem}

O pensamento não determinístico, ocasionado pela aleatoriedade presente nos processos estatísticos, frequentemente se mostra não natural a alunos e professores inexperientes. Raciocinar sobre a incerteza intrínseca aos dados pode conduzir a discussões filosóficas controvertidas, algumas vezes bem distantes da lógica usual.

De acordo com Moore (2001), as informações implícitas nos dados também exigem um certo grau de abstração que não é normalmente encontrado nos alunos iniciantes e que precisa ser desenvolvido para acessar certos tipos de informações implícitas.

Os dados numéricos podem conter informações que não são percebidas por análises superficiais de iniciantes. Um recurso gráfico tem a finalidade de mostrar visualmente determinada situação diminuindo a necessidade de abstração e, de certa, forma facilitar o entendimento da situação em questão que depois pode ser transposta para uma representação unicamente numérica.

Existe uma certa flexibilidade na ordem do aprendizado. Por exemplo, pode-se estudar a variabilidade analisando primeiro os dados numéricos e depois usando um gráfico de pontos ou na ordem inversa, primeiro estudar a variabilidade por meio da visualização dos dados em um gráfico de pontos e depois fazer uma análise dos dados numéricos. Essa ordem depende das possibilidades, tanto dos professores quanto dos alunos. Às vezes os gráficos se mostram intuitivos e favorecem a abstração necessária para compreender certos fenômenos.

Segundo Rees (1995), as principais maneiras pictóricas de representar dados numéricos, consideradas pelo autor como essenciais, são o dot plot (gráfico de pontos), o diagrama de ramo e folhas e o box plot (gráfico de caixas). Sobre as medidas descritivas e a abstração, o autor escreve que essas medidas condensam dados numéricos em medidas mais gerais, porém abstratas.

A linguagem empregada na Estatística também pode ser um impedimento para alguns alunos. Toda linguagem escrita é constituída de símbolos inicialmente fixados com os quais podemos escrever sequências significativas. O emprego correto dos símbolos que uma linguagem utiliza é necessário para expressar pensamentos e se comunicar com outras pessoas além disso, o entendimento também depende do conhecimento da sintaxe da linguagem.

A abstração matemática revela-se no tratamento de relações quantitativas e de formas espaciais, 
destacando-as das demais propriedades dos objetos. 


\section{Capítulo 5}

\section{Inferência Estatística}

Segundo Moore (2000), inferir significa tirar uma conclusão. A Inferência Estatística oferece-nos métodos para tirarmos conclusões sobre uma população a partir dos dados de uma amostra. Para Magalhães e Lima (2011) a Inferência Estatística é um conjunto de técnicas que objetiva estudar a população por meio de evidências fornecidas por uma amostra.

$\mathrm{Na}$ Inferência Estatística tradicional, as conclusões são obtidas com certa margem de erro e portanto não são determinísticas. Isso ocorre porque a análise é realizada a partir de uma amostra, que por mais que tenha sua coleta planejada e selecionada de acordo com todos os procedimentos adequados, não conterá todos os elementos da população, ou seja, não conterá todas as informações que são encontradas na população. Os erros inerentes aos procedimentos inferenciais são ponderados pela probabilidade, que nesse caso serve como referência para se obter uma noção quanto à proximidade das informações amostrais e a realidade populacional. Procedimentos, cujas conclusões estão associadas aos cálculos da margem de erro, constituem o que denominamos Inferência Formal.

Devido a essa característica aleatória, presente nos dados coletados, é possível que, diante de uma mesma situação, sejam obtidas conclusões diferentes. Apesar de alguns procedimentos seguirem etapas bem definidas, isso ocorre devido às diferentes premissas, percepções, interpretações e critérios que cada pesquisador imprime às próprias análises.

$\mathrm{Na}$ escola básica certos conceitos utilizados para as análises estatísticas são considerados sofisticados para uma primeira introdução ao tema, por meio da Inferência Formal. No entanto, é possível orientar os alunos para informalmente fazerem conjecturas a partir do comportamento descritivo dos dados, baseando suas conclusões na variabilidade, no comportamento dos dados da amostra e em outros conceitos fundamentais.

Usaremos o nome Inferência Informal (também usado por outros autores) para esse tipo de procedimento que, de acordo com Ben Zvi e Garfield (2004), é um movimento crescente dentro da Educação Estatística, e que surge devido à necessidade de combater as práticas pedagógicas que dão ênfase à utilização excessiva da Matemática e a mecanização dos procedimentos estatísticos. Nesse sentido, os educadores ligados à Inferência Informal buscam maneiras mais eficientes para introduzir os conceitos fundamentais e algumas ideias, utilizadas na Estatística, que se apresentam, dentro do senso comum, de difícil entendimento imediato para muitos estudantes.

Ben Zvi e Garfield (2004) afirmam que a dificuldade em iniciar o aprendizado de Estatística utilizando procedimentos formais dadas as barreiras criadas pelas regras complexas, situações contra intuitivas, cálculos sofisticados, etc. Esse cenário, às vezes, acaba por gerar um desconforto tanto em alunos quanto em professores quando estes optam por adotar um ensino algoritmizado que 
privilegia o tecnicismo e a aplicação pura e simples de procedimentos. De acordo com Wild et al. (2011), o termo Inferência Informal surgiu devido ao crescimento das pesquisas educacionais na área de Estatística e da necessidade de diálogo entre os pesquisadores.

Assim como a Inferência Formal, a Inferência Informal busca levantar subsídios estatísticos porém a partir de outras análises que não demandam, necessariamente, o conhecimento técnico exigido para aplicação dos métodos formais, buscando a relação dos conceitos básicos e do contexto no qual os dados e o aluno estão inseridos. Independente do tipo de inferência, as conclusões devem ser justificadas porém, na Inferência Informal, são aceitos argumentos nem sempre estritamente teóricos desde que sejam coerentes e façam sentido com o contexto.

Uma pergunta que poderia surgir naturalmente é: se ambos os métodos fornecem informações estatísticas, qual a vantagem de utilizar o método formal tão matematizado? Em resposta podemos dizer que uma das vantagens dos métodos formais é que as conclusões são acompanhadas de uma medida de confiança (probabilidade) que agrega maior ou menor credibilidade às afirmações. A probabilidade utilizada nos métodos formais serve como uma referência na tomada de decisões. Não é possível dizer com absoluta certeza o tempo daqui a sete dias mas dizer que a probabilidade de chuva daqui a sete dias é 0,2 ou dizer que a probabilidade de chuva daqui a sete dias é 0,8 representam impressões diferentes e podem interferir fortemente em algumas decisões, como um plantio, uma viagem, uma competição esportiva, etc.

Quanto aos métodos informais, eles fornecem subsídios desvinculados de medida de confiança, pois a confiança nas afirmações é expressa por aspectos não probabilísticos que têm sua credibilidade mensurada a partir de uma análise subjetiva da coerência entre as afirmações e os dados e também da verbalização da conclusão e do emprego de termos estatísticos. Evidentemente, não se trata de advogar a substituição da Inferência Formal pela Inferência Informal mas sim sinalizar que os primeiros passos sejam dados por meio de conclusões informais, na escola básica, de modo a iniciar o desenvolvimento do raciocínio e pensamento estatísticos.

Segundo Ben Zvi e Garfield (2004), as tentativas de iniciar as noções de Estatística na escola básica foram acompanhadas de cálculos demorados e mecanizados de algumas medidas que geralmente comprometiam o entendimento do problema, fazendo com que o aluno se perdesse nos cálculos e, por vezes, esquecendo o problema inicial. Sem estar preparado adequadamente, o aluno pode passar a maior parte da aula calculando uma coisa que não sabe ao certo o que é, nem para que serve.

Um exemplo seria o cálculo do desvio padrão, que apesar de ser uma medida de dispersão atualmente apresentada nos livros-texto do ensino básico é conceitualmente absorvida por poucos alunos De acordo com Cobb e Moore (1997), o cálculo do desvio padrão, bem como de outras medidas estatísticas, pode ser abordado sob o ponto de vista da Matemática e ser explorado por meio da utilização do algoritmo para obter seu valor. Esse assunto também pode ser explorado do ponto de vista da Estatística e ter seu significado desenvolvido para que possa ser tratado como uma forma de representação numérica das características relacionadas à variabilidade. Em resumo podemos dizer que o cálculo dessa medida é de natureza Matemática enquanto sua interpretação é de natureza Estatística.

Essa prática usual de mecanizar procedimentos tem sido relatada por diversos autores como Ben Zvi e Garfield (2004), Lingyuan et al. (2004) e Moore (2000) que buscam mudar essa realidade por meio de um ensino de estatística adequado à realidade dos alunos do mundo de hoje. A mo- 
bilização desses autores tem promovido a apresentação de caminhos para a análise exploratória de dados sob a conotação de Inferência Informal.

\subsection{Inferência Informal}

O documento ${ }^{1}$ do MEC caracteriza a Inferência como sendo "as estratégias que permitem captar o que não está escrito de forma direta, ou seja, que permitem ler o que não está escrito. "Essas estratégias buscam levantar pistas para se checar alguma suposição e, portanto, não é uma forma de adivinhação como alguns poderiam pensar. Makar e Rubin (2009) consideram que dentro da Estatística, o raciocínio inferencial informal é um processo que permite fazer generalizações com base em dados estatísticos, o que significa estender as conclusões além dos dados. O raciocínio inferencial é composto de diferentes níveis de profundidade, técnicas e detalhes em cada série escolar e pode ir avançando de acordo com a experiência dos alunos.

De acordo com esses autores, a interpretação da estatística passou por melhoras consideráveis com a utilização de gráficos, medidas e procedimentos que surgiram na década de setenta, por meio dos avanços tecnológicos. Em seguida iniciou-se um movimento para disseminar esse novo conhecimento. Mesmo assim, existe uma grande diferença entre o que a Estatística pode oferecer para os alunos do ensino básico e o que é apresentado a estes alunos. Nesse sentido, a Inferência Informal se mostra como uma vertente educacional para atender as necessidades dos alunos de conhecerem os conceitos fundamentais dessa área do conhecimento e utilizá-los quando necessário.

Os conhecimentos acumulados por meio da Inferência Informal possibilitam aos alunos meios não formais de afirmar, alegar, julgar ou questionar algo, alguma situação, também baseados em amostras. Aliás, Zieffler et al. (2008) consideram essa possibilidade como um dos três principais componentes que estruturam o ensino da Estatística por meio da Inferência Informal.

O segundo componente citado pelos autores é a incorporação dos conhecimentos a priori que o aluno possui, não somente os conhecimentos em Estatística, mas também os ligados à situação ou ao contexto nos quais os dados estão imersos e ligados à Matemática. Entre os conhecimentos ligados à Estatística são destacadas as capacidades de reconhecer amostras, distribuições, além de empregar uma linguagem que seja suficiente para expressar suas conclusões. O terceiro componente faz referência às habilidades para articular as evidências e argumentar, com base em amostra(s), sobre população(ões).

Ainda de acordo com Zieffler et al. (2008), a palavra informal é utilizada devido às diferenças quando comparada à Inferência Formal. Como não existe um caminho rígido a seguir, a palavra informal faz referência às diversas possibilidades educacionais que o ensino da estatística apresenta e pode ser contraposta à formal a qual geralmente apresenta caminhos menos flexíveis em seus procedimentos. Os autores alertam para o início da instrução estatística e os fundamentos para construção dos significados envolvendo os conceitos básicos.

Inserido na Inferência Informal está o raciocínio inferencial informal. Este termo aparece frequentemente na literatura sobre a Inferência Informal e, assim como o termo Inferência Informal, não possui uma definição única. Rubin e Hammerman (2006) tratam desse tipo de raciocínio considerando um sinal e um ruído. No caso, o sinal seria uma medida de um parâmetro e o ruído a variabilidade inerente. Pfannkuch (2006) explora o mesmo termo pensando em uma amostra e o

\footnotetext{
${ }^{1}$ http://portaldoprofessor.mec.gov.br/fichaTecnicaAula.html?aula=49268 acessado em 04/02/2016
} 
controle dos erros gerados que podem ser gerados pela variabilidade.

Não só esses autores mas também outros alertam que essa área é recente e carece ainda de muitas pesquisas para responder muitas questões ainda em aberto e que estão diretamente ligadas aos acontecimentos, tanto comuns ou individuais, favoráveis ou contra, que permeiam as atividades educacionais ligadas à Estatística, em particular à Inferência Estatística.

Se os cálculos e os procedimentos puderem ser realizados com o uso de computadores há um certo ganho de tempo que será direcionado para reflexões sobre o significado dos conceitos envolvidos com a expectativa de gerarem melhores resultados. Mesmo assim é indispensável que os alunos, no início da aprendizagem, calculem manualmente esses valores para que sejam consolidados outros aspectos relacionados aos conceitos. Quando for necessário esse tipo de atividade manual, recomenda-se trabalhar com um número pequeno de dados. Para conjuntos grandes de dados, quando não for possível a utilização de um recurso tecnológico para este fim, pode-se apresentar aos alunos os valores das medidas previamente calculados para que sejam interpretadas e utilizadas.

Em todos os casos, os educadores ligados ao ensino da Estatística, citados ao longo deste trabalho, que seguem essa linha chamada de Inferência Informal, buscam introduzir e desenvolver os conceitos estatísticos por meio de exemplos concretos que estão o mais próximo possível do contexto vivido pelos alunos, sempre que possível por meio de situações extraídas diretamente do seu cotidiano.

A comparação entre dois grupos é uma das estratégias que apresenta boa resposta quanto à compreensão desses conceitos. Medidas descritivas e gráficos (como a introdução do box plot ou gráficos de caixas) transmitem um resumo do comportamento dos dados assim como seu aspecto visual, que serão fundamentais para orientarem as análises feitas por meio dos dados. Voltaremos oportunamente a esse tipo de exemplo no Capitulo 6.

\subsection{Inferência Formal}

No início deste capítulo, comentamos sobre a existência de dificuldades na aprendizagem da Inferência Formal na escola básica (dificuldades essas também existentes nas disciplinas introdutórias dos cursos universitários). Voltando a Zieffler et al. (2008), o que mais diferencia a Inferência Informal da Inferência Formal é que esta última utiliza métodos como, por exemplo, testes de hipóteses e intervalos de confiança, entre outros, para tirar conclusões, métodos estes baseados em uma estrutura de lógica formal, nem sempre compreendida pelos alunos. Esses métodos estão relacionados, mas neste trabalho discutiremos apenas os princípios da lógica do teste de hipóteses para o qual será desenvolvido, posteriormente, um exemplo de comparação de grupos.

Batanero (2001) também alerta sobre a estrutura lógica de difícil compreensão, mesmo para alunos universitários de ciências empíricas, cujas análises, em geral, dependem fortemente de análises estatísticas de dados para avaliar a existência de efeitos e estabelecer relações. Sua crescente utilização tem gerado algumas críticas envolvendo a interpretação nem sempre correta das informações obtidas. Algumas das dificuldades envolvendo os testes de hipóteses serão discutidas nas duas próximas seções e no Capítulo 6 será apresentado um exemplo com discussão da resolução passo a passo. 


\subsubsection{Os Testes de Hipóteses e o Raciocínio Lógico}

Como já mencionado, a estrutura de construção dos testes de hipóteses, uma das ferramentas mais usadas em Estatística pelas ciências aplicadas, segue o raciocínio da lógica formal condicional, estrutura essa que será descrita sucintamente a seguir.

Um teste de hipóteses é um procedimento inferencial que consiste no estabelecimento de duas hipóteses ( $H_{0}$, hipótese nula em sua forma mais simples representando uma igualdade, e $H_{a}$, hipótese alternativa) que dizem respeito aos parâmetros de uma ou mais populações. Por exemplo, ao comparar dois grupos (duas populações) quanto à média de desempenho em uma disciplina, pode ser de interesse do pesquisador estabelecer

$H_{0}$ : Média populacional do grupo 1 = Média populacional do grupo 2

$H_{a}$ : Média populacional do grupo $1 \neq$ Média populacional do grupo 2

Com base nos dados a serem coletados, o procedimento permite rejeitar a Hipótese nula ou não rejeitar a Hipótese nula, tendo uma probabilidade associada como critério do risco inerente à decisão.

A construção é baseada no raciocínio dedutivo, oriundo da lógica condicional, na expressão do tipo Se ..... Então ....., discutida em Cordani (2001).

O raciocínio condicional se apresenta de duas formas:

1 - modus ponens - (modo afirmativo)

- Se acontecer P então acontecerá Q (premissa condicional)

- P aconteceu (premissa categórica); logo, Q também aconteceu

Notação:

Se P então Q

$\mathrm{P} \log 0 \mathrm{Q}$

2 - modus tollens - (modo negativo)

- Se acontecer P então acontecerá Q (premissa condicional)

- Q não aconteceu (premissa categórica); logo, P também não aconteceu.

Notação:

Se P então Q

não $\mathrm{Q} \log$ não $\mathrm{P}$

Em estruturas deste tipo, P é denominado de antecedente e Q de consequente. É importante notar que as premissas $\mathrm{Q}$ aconteceu ou mesmo $\mathrm{P}$ não aconteceu, não permitem conclusões válidas.

Ilustraremos essa situação com o exemplo a seguir. Considere a seguinte frase: 
Se apertar o botão (P) então a lâmpada se apaga (Q) *

Vamos estabelecer duas situações:

1 - Ocorreu P (botão foi apertado); então ocorrerá Q (lâmpada se apaga) - modus ponens.

Diante disso, considerando a frase * verdadeira e constatando que ocorreu o antecedente $(\mathrm{P}$ botão foi apertado) então certamente ocorre Q (a lâmpada apagará).

2 - Não ocorreu Q (ou seja, a lâmpada não apagou); então não ocorreu $P$ (ou seja, não foi apertado o botão)- modus tollens.

Diante disso, considerando a frase * verdadeira e constatando que não ocorreu o consequente $\mathrm{Q}$ (não Q - a lâmpada não apagou), então certamente não ocorreu $\mathrm{P}$ (não $\mathrm{P}$ - não foi apertado o botão).

Obs. As situações não ocorreu P (não foi apertado o botão) ou então ocorreu Q (a lâmpada apagou) não permitem conclusão válida.

Os testes de hipóteses foram construídos baseados no modelo da lógica condicional modus tollens e sua construção parte de hipóteses construídas pelo pesquisador, como o exemplo colocado no início desta seção. O que essa teoria oferece são meios de determinar a falsidade de afirmações (hipóteses) pela negação (refutação) que é um raciocínio não intuitivo.

A partir das hipóteses colocadas no início da seção, o procedimento considera a seguinte estrutura condicional:

P é o antecedente - Hipótese $H_{0}$ é verdadeira e

Q é o consequente - os dados deverão se comportar de certo modo.

Tomando o raciocínio modus tollens, temos

Se P então $Q$ - observado não $Q$ - logo não $P$.

Isto é, se a hipótese nula $H_{0}$ (médias dos grupos são iguais) for verdadeira $(\mathrm{P})$ então as médias das amostras devem se comportar de certa maneira (Q). Caso os dados não se comportem da maneira determinada (não Q), então $H_{0}$ não é verdadeira (não P). Neste caso então, de rejeitar $H_{0}$, decidimos por $H_{a}$ e esta decisão é acompanhada de uma dose de risco quantificada por uma probabilidade. Caso os dados se comportem daquela maneira (Q), nada sabemos sobre $H_{0}$.

Ou seja, o objeto sobre o qual uma decisão tem que ser tomada é a hipótese $H_{0}$ : com base nos dados ou ela será rejeitada (não P) ou então nada se poderá dizer sobre ela. Assim a essência do mecanismo formal não está em afirmar hipóteses e sim desmenti-las; se for o caso. Ao rcjeitar $H_{0}$, o procedimento sugere considerar como válida a hipótese $H_{a}$ (sempre levando em conta o risco associado, quantificado pela probabilidade).

Os métodos estatísticos, por mais sofisticados que sejam, não são suficientes para se afirmar, 
com certeza, sobre a veracidade de uma afirmação. Na verdade, o que oferecem é a possibilidade de refutar uma hipótese ou , caso contrário, não apresentar nenhuma conclusão. A partir de evidências fornecidas por uma amostra, uma vez refutada uma hipótese, a teoria Estatística fornece apoio probabilístico que ajuda na formulação de uma conclusão. Caso não haja evidências para se refutar a hipótese, nada poderá ser concluído.

Tanto erros na elaboração quanto na interpretação das hipóteses de um teste podem conduzir a situações paradoxais. É preciso distinguir os papeis da hipótese nula, da hipótese alternativa e da hipótese de pesquisa. De acordo com Batanero (2001), existem confusões entre as consequências de se considerar verdadeira ou falsa a hipótese nula. Esses erros conceituais ligados ao mecanismo lógico do teste de hipótese têm relação com o modo dedutivo de se concluir sobre o teste por meio do já comentado procedimento modus tollens.

Situações paradoxais podem surgir de interpretações equivocadas de um teste de hipóteses mesmo que este teste seja realizado corretamente. Por exemplo, considerar o procedimento de teste de hipóteses como uma prova probabilística para a hipótese a ser testada ou mesmo como uma prova matemática para a veracidade da hipótese são concepções equivocadas, que não são suportadas pelo mecanismo de construção desta ferramenta. De acordo com Batanero et al. (2011), podemos sim considerá-lo como uma regra de decisão ou mesmo como um procedimento empírico para obtenção de um suporte para a hipótese considerada. Considerar que a rejeição da hipótese nula implica que esta é absolutamente errada é uma evidência de que o interessado no teste de hipótese não compreendeu os propósitos desse teste, sua lógica de construção e a incerteza que está presente em todos os procedimentos formais. Esse equívoco está entre os mais comuns e mais graves cometidos na realização de um teste de hipóteses.

\subsubsection{Os Testes de Hipóteses e Outros Procedimentos Associados}

Dentro da estatística clássica, a escolha da amostra é uma etapa que influencia todo o processo posterior da análise dos dados. Se ela for planejada sem cuidados poderá distorcer a situação que realmente ocorre na população ou não conter dados suficientes para uma conclusão com respaldo adequado.

De acordo com Moore (2000), para garantir uma certa imparcialidade na amostra devemos obtêla a partir de algum procedimento aleatório. Procedimentos não aleatorizados podem transferir para a amostra algum tipo de distorção que influencia as conclusões sobre os dados. Em qualquer análise exploratória de dados um dos cuidados a se tomar com a escolha da amostra é adotar um procedimento aleatório que tem como vantagem, agregar confiabilidade aos resultados provenientes das amostras. É bom salientar que essa aleatoriedade nem sempre é possível de ser obtida, o que pode limitar as conclusões de métodos de Inferência Formal.

Quando se fala em amostra, além do caráter aleatório mencionado, é muito importante discutir o tamanho desta amostra (ou seja, o número a ser coletado de unidades amostrais) de modo a se ter mais controle do risco da tomada de decisão. É até fácil de ser absorvido intuitivamente pelos alunos que quanto maior for a amostra maior será a precisão que podemos obter na análise. Estes fatos podem ser comprovados por simulação ou por considerações teóricas.

$\mathrm{Na}$ seção anterior foi mencionado que as hipóteses (de um teste de hipóteses) se referem a parâmetros os quais, por sua vez, são quantidades desconhecidas associadas a uma característica de interesse (chamada de variável) associada a uma ou mais populações. No exemplo dado, tratava-se 
de comparar o desempenho de dois grupos por meio de duas médias populacionais (a quantidade desconhecida é a média do grupo e a variável é o desempenho, cuja medida é especificada pelo pesquisador - nota, por exemplo).

Como vamos recorrer a amostras para resolver o problema, devemos escolher um representante dos parâmetros populacionais nestas amostras, que são os chamados Estimadores. A escolha de um estimador, que será função dos valores da amostra, é um passo muito importante que irá dirigir o tipo de análise a ser usada. No exemplo mencionado, para estimador das médias populacionais usaremos as médias das amostras (médias amostrais), conforme Magalhães e Lima (2011).

Essas médias amostrais (aleatórias) têm um comportamento bem conhecido na literatura, as chamadas distribuições amostrais, que são modelos matemáticos associados a componentes probabilísticos. Moore (2000) se refere à distribuição amostral como sendo a distribuição dos valores que uma estatística pode assumir em cada uma das amostras, de um mesmo tamanho, que podem ser coletadas de uma mesma população. $\mathrm{O}$ tamanho da amostra tem um papel decisivo para diminuir a variabilidade associada ás distribuições amostrais, ou seja, quanto maior a amostra, menor a variabilidade associada à distribuição amostral, o que confere maior precisão às análises. Essa prática envolve um diálogo entre os modelos teóricos e os dados, por meio do qual busca-se refutar ou não uma hipótese.

A seção 5.4 discute um pouco mais a importância das distribuições amostrais mas para mais detalhes técnicos sobre esse tema ou Estimadores ver, por exemplo, Magalhães e Lima (2011).

\subsubsection{Dificuldades da Abordagem Formal na Escola Básica}

Todo esse arcabouço teórico é muito pesado para uma primeira análise de um problema e dificulta a possibilidade de uma reflexão sobre o raciocínio estatístico. Pela complexidade, muitas abordagens se restringem meramente aos cálculos e os resultados são encarados pelos alunos como verdadeiras caixas-pretas.

Sotos et al. (2007) relatam que muitas pesquisas mostram uma profunda lacuna que separa os estudantes das ideias fundamentais da Estatística, em particular da Inferência Estatística. Isso pode demostrar que as práticas que priorizam os cálculos não funcionam bem quando se trata de entendimento. É necessário tentar meios e atividades que promovam a aprendizagem e combatam esse modo antiquado e pouco eficiente de iniciar e desenvolver o Ensino de Estatística.

Autoridades educacionais de alguns países, como Nova Zelândia, Espanha e Austrália incluíram a Inferência Estatística no currículo escolar dos últimos anos do ensino pré-universitário. De acordo com Franklin et al. (2005), nesses programas é possível encontrar elementos da Inferência Estatística implícitos em tópicos do currículo não necessariamente ligados à Estatística ou à Matemática. É possível também obter instruções sobre como desenvolver os fundamentos da Estatística e da inferência de acordo com o conhecimento apresentado pelo aluno e não necessariamente de acordo com a idade.

\subsection{Distribuição Amostral}

A distribuição amostral é um elemento indispensável quando se trata de Inferência Estatística. Ela é usada nos testes de hipóteses. Sua importância provém da possibilidade de fornecer informações sobre uma população embora nem todas as informações possam ser extraídas. 
Batanero et al. (2011) entre outros, afirmam que para que um estudante raciocine sobre distribuição amostral é necessária a integração de vários conceitos estatísticos e algum conhecimento acerca do comportamento da variável em estudo. Ainda nesse sentido, um raciocínio minimamente suficiente para trabalhar com a distribuição amostral se mostra inacessível para alguns estudantes devido a uma abordagem estritamente técnica, deixando em segundo plano as questões ligadas a interpretação.

Para que isso não ocorra é indispensável uma distinção clara entre população, amostra e espaço amostral. Quando possível, é aconselhável a familiarização com o processo de coleta de dados, por meio da participação do estudante na realização dessa coleta. Dessa maneira, pode se aproximar o sujeito do seu objeto de estudo. Além dessa aproximação, uma discussão sobre os resultados obtidos na coleta de dados tem se mostrado importante no entendimento dos conceitos relacionados.

Harradine et al. (2011) referem que não costuma ser clara a diferença entre população, amostra e coleção de amostras. Este último item está diretamente relacionado com a distribuição amostral de um estimador.

Alguns alunos apresentam grandes dificuldades para perceber que, diante de uma população com um número finito de elementos, é possível extrair diversas amostras com um tamanho fixo. Sendo $\mathrm{n}$ esse número previamente fixado, é possível extrair várias amostras contendo $\mathrm{n}$ elementos. Suponha que sejam extraídas da população todas as amostras possíveis que contenham $\mathrm{n}$ elementos e, para cada uma das amostras, seja calculado o valor de um certo parâmetro, ou seja a estimativa. Após calcular todos esses valores e organizá-los é possível que exista um padrão entre eles. Esse padrão é o que se costuma chamar de distribuição amostral.

De acordo com Harradine et al. (2011), e para tantos outros autores, compreender o que é a distribuição amostral é uma das maiores dificuldades relacionadas ao ensino da Estatística. Nesse sentido, o que mais se recomenda é a simulação, ou seja, a repetição do processo de coleta de dados. Para isso coleta-se várias amostras de uma mesma população e verifica-se os valores de um certo estimador.

Inicialmente é melhor realizar esse processo manualmente com situações reais, dentro da própria classe envolvendo os alunos. Isto é factível em se tratando de pequenos conjuntos. Em outros momentos, quando a população ou a amostra possuem um número grande de elementos os recursos computacionais são mais indicados.

Mesmo sendo fortemente recomendada, por Harradine et al. (2011), a utilização da tecnologia não é suficiente para promover um entendimento pleno desse conceito. Para isso os autores recomendam que, além da simulação manual e da utilização de recursos computacionais, os professores promovam a discussão das observações entre os alunos e com os alunos.

\subsection{Teste de Hipóteses}

Os estimadores para média apresentados anteriormente, que fornecem como estimativa um único valor numérico, são classificados como estimadores pontuais. Por exemplo, a média populacional de uma variável quantitativa geralmente tem como estimador a média amostral associada a dados de uma amostra coletada da referida população. Então a média amostral é um estimador pontual da média populacional. Como para cada amostra temos um valor para o estimador, ele é considerado uma variável (aleatória), possuindo então uma distribuição de probabilidade. Esta distribuição será 
usada na construção de uma certa classe de teste de hipóteses (Neyman Pearson), e é esta que será analisada neste trabalho.

Situações paradoxais podem surgir de interpretações equivocadas de um teste de hipóteses mesmo que ele seja realizado corretamente. Há uma confusão frequentemente gerada na definição de uma hipótese nula, $H_{0}$, e uma hipótese alternativa, $H_{a}$, que esta relacionada com o raciocínio lógico utilizado, no caso o modus tollens, que por vezes se mosra contra intuitivo.

Batanero et al. (2011) discutem dificuldades de professores e alunos da escola básica na interpretação de testes de hipóteses, como por exemplo, achar que é uma prova probabilística para a hipótese ou que é uma prova matemática para a verdade de uma hipótese. Esses equívocos, muito comuns, demonstram a pouca familiaridade com o desenvolvimento da teoria dos testes, e com a correspondente possibilidade de análise.

As premissas que o teste formal exige e a amostra em mãos conduzem algumas vezes à necessidade de adaptar a questão inicial para que seja possível o teste de hipóteses. A partir dessa questão é necessário traduzir a pergunta para uma forma na qual seja possível aplicá-lo. Traduzir isto para a linguagem formal é uma tarefa que exige um certo conhecimento teórico sobre o assunto, e por isso se torna para alguns alunos uma barreira a ser superada.

De acordo com Godino (2005), a linguagem simbólica pode dificultar o entendimento desse tipo de teste uma vez que é por meio dela que se manifestam e se comunicam as ideias. De acordo com Harradine et al. (2011), o erro conceitual mais frequente relacionado às hipóteses nula e alternativa é acreditar na veracidade absoluta de uma das duas hipóteses.

Ao realizar o teste de hipóteses assumimos que se $H_{0}$ for verdadeira "algumas coisas" devem acontecer e a partir dessa suposição verificamos se realmente acontecem. Se essas coisas não acontecem assume-se que $H_{0}$ não é verdadeira. Porém, assumir que uma hipótese é verdadeira não significa que ela realmente o seja.

Nesse ponto muitos alunos se enganam e, de acordo com Godino (2005), utilizam a intuição pessoal e uma visão pragmática, desconsiderando os conceitos envolvidos. Como consequência acabam por assumir a veracidade absoluta de uma hipótese quando constatam que a outra provavelmente é falsa.

Mesmo que o teste revele que $H_{0}$ é falsa, não é certeza de que ela realmente o seja, uma vez que o teste é estabelecido dentro de alguns limites de incerteza. Usando um nível de significância de 5\% espera-se que $5 \%$ das conclusões que decidam pela rejeição de $H_{0}$, quando $H_{0}$ é verdadeira, sejam equivocadas.

Esta análise será retomada na Seção 6.2. 


\section{Capítulo 6}

\section{Comparação Entre Dois Grupos}

Os saberes associados à Estatística auxiliam na leitura e compreensão do mundo pois contribuem para o aumento na qualidade das decisões, julgamentos, argumentações e inferências que os alunos venham a realizar tanto no ambiente escolar quanto fora dele. De acordo com Gal et al. (1989), quanto antes uma pessoa adquire conhecimentos em Estatística, mais rápido ela pode compreender algumas situações sociais e exercer cidadania.

Uma abordagem repleta de possibilidades educacionais, tanto ligadas à Estatística como a outras matérias ou conteúdos, é a comparação entre grupos. Comparar, de um modo geral, é uma prática comum, base de muitas escolhas. Por meio da comparação observamos em diversas situações aspectos a favor, contra ou indiferentes. Comparando, elaboram-se critérios que ajudam a escolher, a decidir ou desenvolver uma certa preferência por algo ou alguma situação.

Para Watson e Moritz (1999), a comparação entre grupos ocorre naturalmente entre as pessoas. Apesar de existirem diversas possibilidades para se introduzir ideias em Estatística, as atividades que envolvem a comparação entre grupos têm mostrado resultados positivos nos alunos em níveis iniciais, ou seja, nos primeiros contatos com o assunto.

Devido à importância da comparação na tomada de decisões, Gal et al. (1989), Zieffler et al. (2008), Pfannkuch (2006), entre outros autores, sugerem utilizar a comparação entre dois grupos como um ponto de partida para desenvolver os princípios da Estatística. Uma das vantagens de utilizar a comparação entre dois grupos como um recurso de ensino é a facilidade de encontrar um tema de interesse devido às grandes possibilidades de interdisciplinaridade que a Estatística permite. A comparação entre dois grupos, utilizando problemas reais do cotidiano dos alunos, tem se mostrado mais ligada a aplicações da estatística fora dos muros da escola, diferentemente dos exemplos teóricos, muitas vezes distantes da realidade deles que podem desestimular o aprendizado.

Segundo Zieffler et al. (2008), o recurso da comparação pode utilizar todos os conceitos fundamentais em um único problema mas também pode ser explorado de modo simples por meio de um único conceito. A comparação é recomendada também pelos documentos do MEC, em Brasil (1997), que destacam a transdisciplinaridade e o potencial agente motivador desse recurso:

"Construir o significado das medidas, a partir de situações-problema que expressem seu uso no contexto social e em outras áreas do conhecimento e possibilitem a comparação de grandezas de mesma natureza".

A comparação mais simples entre dois grupos ocorre em relação a uma certa característica: o que de fato se compara é alguma grandeza comum a esses grupos. Para isso, o uso de métodos quantitativos têm grande utilidade, desde níveis simples e imediatos, a serem explorados por alunos 
iniciantes, até níveis sofisticados, por pesquisadores e cientistas.

Apesar disso, comparar nem sempre é uma tarefa simples. Algumas situações podem necessitar de uma análise mais profunda e exigir um conhecimento pleno de Estatística. Mesmo assim, é possível lançar diversos olhares sobre um mesmo problema. Há ocasiões em que um mesmo assunto pode ser analisado de maneira simples, com poucas medidas ou também de maneira mais ampla em diversos níveis de aprofundamento. Assim, no ambiente escolar, diversos assuntos podem ser explorados e aprofundados de acordo com o entendimento dos alunos.

\subsection{Explorando a Comparação Entre Dois Grupos}

Como proceder então a uma abordagem estetística de comparação entre dois grupos? Sugerimos partir de uma questão inicial, associada a uma pesquisa de interesse, para depois verificar os passos a serem seguidos. De acordo com Huber (2011), os conhecimentos necessários para compreender dados estatísticos englobam saberes que incluem coleta de dados e planejamento para essa coleta, tendo o cuidado com fatores humanos e erros sistemáticos que podem influenciar os dados.

Responder a questão de interesse nem sempre é possível. De acordo com Pfannkuch e Horton (2009), as limitações impostas pela amostragem obriga, em alguns casos, a adequar as questão de interesse para uma questão mais específica e que pode ser respondida de acordo com a disponibilidade.

Consideremos o seguinte cenário: um secretário de educação gostaria de saber se o rendimento (aprendizagem) dos alunos do diurno é diferente daquele dos alunos do noturno e pediu a um diretor de escola pública da cidade para fazer esta verificação. Embora a expectativa do secretário fosse ter uma resposta global para escolas públicas em geral, o diretor optou pela simplificação de comparar o desempenho em Matemática do último ano do ensino médio em sua escola, usando para isto as notas finais dos alunos desta disciplina nos dois períodos (diurno e noturno).

Assim, a questão inicial sobre o rendimento entre os períodos deu lugar à seguinte questão: As notas finais em Matemática dos alunos do período diurno são diferentes das notas finais em Matemática dos alunos do período noturno?

Mesmo tendo em vista a necessidade da restrição feita pelo diretor, vamos aqui fazer uma suposição de que as classes a serem consideradas representam uma amostra aleatória das possíveis classes de $3^{\circ}$ ano médio de escolas públicas da cidade. Seria algo como dizer que as notas obtidas nessa escola poderiam bem terem vindo de qualquer outra escola da mesma população. Aceitando esta visão e lembrando ao leitor que isto é uma simplificação, vamos então discutir como usar a estatística para responder a esta pergunta.

Temos aqui duas populações a serem consideradas: uma delas é o conjunto de alunos do diurno de escolas públicas da cidade e a outra é o conjunto de alunos do noturno de escolas públicas da cidade, ambas representadas respectivamente pelas amostras já comentadas (diurno e noturno). Na situação em questão, não foi possível seguir uma recomendação importante de Pfannkuch e Horton (2009), que seria a aleatorização do processo de coleta de dados em nível da idade, estadual ou mesmo nacional, ou seja, em diversas escalas de abrangência. Nesse exemplo, como já dissemos, a coleta de dados ficará restrita a uma escala bem menor e serão utilizados os dados coletados unicamente em uma única escola.

A Estatística apresenta ferramentas para se passar do âmbito particular (amostra) para o geral 
(população) que são procedimentos, já comentados neste trabalho, da chamada área de Inferência Estatística. Estes procedimentos dizem respeito geralmente à chamada Inferência Formal com técnicas bem delineadas na literatura estatística que é o que analisaremos na seção 6.2. Para efeito de comparações deste tipo que estamos analisando, a Inferência Estatística dispõe de vários métodos e vamos aqui escolher o teste de hipótese para duas médias. Esta técnica vai ser analisada passo a passo, com destaques para os principais obstáculos que os alunos da escola básica enfrentariam para sua compreensão. Na seção 6.3 analisaremos uma abordagem que muitos autores (como por exemplo Pfannkuch (2006)) sugerem ser mais adequada para iniciar os alunos no raciocínio inferencial que é a chamada Inferência Informal.

\subsection{Comparação Entre Dois Grupos - Uso de Inferência Formal}

Os passos da Inferência Formal são descritos em vários textos básicos de estatística com algumas diferenças na definição da estratégia de análise. Aqui vamos optar por Agresti e Franklin (2007), que listam as etapas de um teste de hipóteses:

$1^{\text {a) }}$ Elaborar as suposições iniciais (variável a ser estudada, parâmetro a ser considerado, tipo de amostragem usado);

$2^{\text {a }) ~ E s t a b e l e c e r ~ a ~ h i p o ́ t e s e ~ n u l a ~ e ~ a ~ h i p o ́ t e s e ~ a l t e r n a t i v a ~ r e f e r e n t e s ~ a o ~ p a r a ̂ m e t r o ~ d e ~ i n t e r e s s e ~ e ~ a ̀ ~}$ pergunta inicial;

$3^{a}$ ) Identificar a estatística do teste (ou seja, quem na amostra corresponde ao parâmetro de interesse do item anterior);

$4^{\text {a }) ~ I n t e r p r e t a r ~ a ~ e s t a t i ́ s t i c a ~ d o ~ t e s t e ; ~}$

$5^{\mathrm{a})}$ Apresentar conclusão.

Cada uma das etapas acima será desenvolvida a seguir com uma breve discussão de eventuais problemas de compreensão por parte dos alunos iniciantes no tema.

$1^{\mathrm{a}}$. Etapa: suposições iniciais (variável a ser estudada, parâmetro a ser considerado, tipo de amostragem usado)

No exemplo em questão deseja-se verificar se existe alguma diferença entre a aprendizagem das turmas do período diurno e do período noturno. Mas o termo aprendizagem pode parecer vago o que possibilita a indagação: como a aprendizagem pode ser representada? Ou seja, qual a medida que mede aprendizagem? Nesse ponto teríamos uma discussão ao nível de Educação (ou Psicologia) para saber qual a característica usada para representar aprendizagem.

Uma candidata (no processo simplificado que mencionamos) dentro do contexto que estamos analisando, já escolhida pelo diretor da escola, seria nota em Matemática. Dizemos na linguagem da Estatística que nota em Matemática é a variável a ser estudada. Uma vez que se decida pela nota em Matemática, o passo seguinte seria escolher alguma medida resumo desta variável, ou seja, alguma medida que representasse a aprendizagem. Qual seria uma medida adequada para resumir notas? Essa medida resumo é o que se chama em Estatística de parâmetro. Há várias possibilidades, que produziriam uma boa discussão, mas vamos escolher o parâmetro mais comum: a média das notas.

Então vemos que de aprendizagem, um conceito bem geral e difícil de "medir", passamos para 
média de notas de Matemática, que é uma parte da aprendizagem. Sabemos que uma nota não pode representar todos os aspectos envolvidos na aprendizagem durante a vida escolar, ou seja, admitimos que é um fator limitante, não há dúvida, mas, de acordo com o cenário apresentado, é o encaminhamento possível para iniciar uma análise inferencial.

Quando se pretende realizar uma pesquisa estatística, em particular ao comparar dois grupos, é necessário tomar alguns cuidados antes da coleta dos dados e também durante a mesma. Esses cuidados dizem respeito às respostas que podemos obter a partir das seguintes perguntas: Serão retiradas informações de um indivíduo mais de uma vez? Ou só seria uma vez? Serão verificadas quantas características? Os dados serão coletados em mais de um momento? Quantos? Os dados serão coletados em mais de um lugar? Quais? Essas e outras perguntas orientam o pesquisador e ajudam a selecionar adequadamente uma amostra de modo a garantir informações fidedignas na amostra. Neste caso, temos a variável nota, o parâmetro média das notas de Matemática e duas amostras independentes (pessoas diferentes e com a suposição de notas independentes). É importante também lembrar que já declaramos que, em nosso contexto, diurno e noturno representam uma população mais geral do que o grupo da escola, de onde as amostras foram retiradas. Esta etapa não apresenta muitos problemas de entendimento para o alunos exceto algumas definições formais como variável, parâmetro, técnicas de amostragem.

$2^{\text {a }}$. Etapa: estabelecer a hipótese nula e a hipótese alternativa

Diante do interesse sobre a aprendizagem nos dois períodos podemos argumentar que ela pode ou não ser a mesma. Como a Inferência Formal trata disso? Na etapa 1 já caracterizamos a variável (nota) e o parâmetro (média). Um teste de hipótese é um procedimento que contrapõe duas hipóteses: a hipótese nula (geralmente uma igualdade) e uma hipótese alternativa (complementar à hipótese nula), e usa um raciocínio da lógica formal(modus tollens) para rejeitar ou não a hipótese de nulidade. Neste caso temos então:

HIPÓTESE 1: A média de Matemática do diurno é igual à média de Matemática do noturno

HIPÓTESE 2: A média de Matemática do diurno é diferente da média de Matemática do noturno

Trabalhar com lógica ainda não é muito natural na escola básica, e a linguagem simbólica pode dificultar o entendimento desse tipo de procedimento, uma vez que é por meio dela que se discutem as ideias.

Ao estabelecer as hipóteses, damos uma conotação mais abrangente do que simplesmente a das classes analisadas, pois a inferência pretende partir do particular para o geral. Em outras palavras, o diretor quer saber de modo geral se noturno e diurno têm aprendizagens diferentes e usa dois grupos para responder a essa questão. Além disso, quando se fala em média de Matemática no contexto de cada hipótese, a referência é a média de uma população da qual a amostra de alunos foi retirada. Isso significa que cada classe pode ser considerada como padrão de um modclo de classe diurna (ou noturna) o que por si só é uma restrição muito forte. Mas aqui o que se pretende é dar visibilidade às dificuldades didáticas para a apreensão das etapas da Inferência Formal para um aluno da escola média. Assim, vamos prosseguir na análise, supondo então que a classe diurna (e/ou noturna) seja uma boa representante das escolas sob consideração, já descrito na $1^{\text {a }}$ Etapa.

Voltando às hipóteses, elas se referem a uma quantidade (média de Matemática) escolhida 
aqui para representar a aprendizagem. A área de estatística convencionou usar uma letra grega, geralmente denotada para representar média populacional. Assim, as hipóteses ficariam:

HIPÓTESE 1: $\mu($ diurno $)=\mu($ noturno $)$

HIPÓTESE 2: $\mu($ diurno $) \neq \mu($ noturno $)$

A notação mais concisa é mais elegante mas a mais extensa, como a utilizada inicialmente, tem vantagens educacionais por ser menos abstrata. Fazer constantemente a passagem entre uma e outra remete os alunos a uma situação que faz mais sentido a eles, até se acostumarem com a notação concisa.

Mais ainda, simplificando para a notação usual, a HIPÓTESE 1 que traduz a igualdade é chamada de HIPÓTESE NULA $\left(H_{0}\right)$ - uma possível explicação (para o termo NULA) é outra representação para $H_{0}$ ou seja, a diferença entre as médias ser nula $[\mu($ noturno $)-\mu($ diurno $)=0]$. Por sua vez, a HIPÓTESE 2 é chamada de HIPÓTESE ALTERNATIVA $\left(H_{a}\right)$. A notação fica mais simples ainda:

$$
\left\{\begin{array} { l } 
{ \mathrm { H } _ { 0 } : \mu ( \text { diurno } ) = \mu ( \text { noturno } ) } \\
{ \mathrm { H } _ { a } : \mu ( \text { diurno } ) \neq \mu ( \text { noturno } ) }
\end{array} \quad \text { ou } \left\{\begin{array}{l}
\mathrm{H}_{0}: \mu(\text { diurno })-\mu(\text { noturno })=0 \\
\mathrm{H}_{a}: \mu(\text { diurno })-\mu(\text { noturno }) \neq 0
\end{array}\right.\right.
$$

O parâmetro aqui pode ser considerado como sendo a diferença entre as médias populacionais (diurno-noturno). O teste consiste então em construir uma estrutura que permite rejeitar ou não rejeitar a HIPÓTESE NULA $\left(H_{0}\right)$. Se rejeitamos $\left(H_{0}\right)$, a HIPÓTESE ALTERNATIVA é plausível. Se não rejeitamos $\left(H_{0}\right)$ nada podemos concluir.

\section{$3^{\text {a }}$. Etapa: Identificar a estatística do teste}

O que vem a ser a "estatística do teste"? Resumidamente, seria o correspondente na amostra ao parâmetro da população. Aqui é preciso dirimir a confusão entre Estatística (metodologia) com estatística (alguma função dos dados observados). O contexto em geral se encarrega de deixar isso claro.

As estatísticas usadas são as médias de Matemática obtidas nas amostras do diurno e do noturno e neste problema a chamada estatística do teste (aquela que vai ser usada para tomar decisão com relação às hipóteses) é a diferença entre as médias das amostras (diurno e noturno), ou seja, procuramos calcular na amostra uma quantidade equivalente ao parâmetro da população em estudo. Essa quantidade correspondente ao parâmetro é uma estatística e é denominada Estimador do parâmetro e, no caso da média, é denominada Média Amostral e denotada por $\bar{X}$, ou seja, a média amostral $\bar{X}$ é um estimador do parâmetro $\mu$ (média populacional). Mas, diferentemente do parâmetro, que é um valor fixo na população (dentro da Estatística clássica), amostras diferentes geralmente conduzem a valores diferentes de um mesmo estimador.

Dessa maneira, conforme comentam Magalhães e Lima (2011), não podemos saber antecipadamente o valor que será fornecido pelo estimador e, portanto, é necessário um tratamento probabilístico. Para cada amostra possível (de mesmo tamanho n) temos um valor da média amostral, 
e podemos então pensar no comportamento probabilístico dessa média amostral. O que seria um comportamento probabilístico? Seria saber qual a distribuição de probabilidade associada aos valores da média amostral - que seria o que se denomina de distribuição amostral, comentada na seção 5.3 .

Essas considerações demandam um olhar mais sofisticado para uma primeira análise inferencial por parte de alunos do ensino básico. O entendimento de uma distribuição amostral é lento e adquirido após uma certa maturidade com análise exploratória de dados. No exemplo dado temos não somente uma população mas sim duas (noturno e diurno) e o interesse é na diferença entre as médias. Resumindo, para o parâmetro $[\mu($ noturno $)-\mu($ diurno $)]$ temos o correspondente estimador ( $\bar{X}$ diurno - $\bar{X}$ noturno) nas amostras associadas ao problema. Mas o comportamento de ( $\bar{X}$ diurno $\bar{X}$ noturno) no sentido probabilístico não é simples de ser mostrado teoricamente - poderia ser feito com simulação, se houvesse recursos tecnológicos.

Essa dificuldade pode ser contornada em sala de aula, fazendo retiradas de amostras pequenas de duas populações bem definidas, e estudando o comportamento das diferenças das médias - isso daria aos alunos a ideia do que seria uma distribuição amostral, embora não dê os recursos teóricos para construir a distribuição associada.

Como comentado em Magalhães e Lima (2011), é necessário definir o comportamento probabilístico de (X $\bar{X}$ diurno - $\bar{X}$ noturno) para avaliar se o valor observado nas amostras dadas são muito prováveis ou pouco prováveis, caso as médias do noturno e diurno sejam iguais. Este ponto é crucial e é aqui que vemos o divisor de águas para um entendimento do processo formal por parte dos alunos da escola básica - a $1^{\mathrm{a}}$ e a $2^{\mathrm{a}}$ etapas. A nosso ver, são trabalháveis no ensino médio sem grande dificuldade mas esta $3^{\mathrm{a}}$. etapa precisa de um entendimento maior sobre a teoria estatística. Vamos verificar como poderia ser conduzido um raciocínio simplificado em torno do tema, o que não significa que deixe de ser complexo para uma primeira abordagem:

- Se as médias das duas populações (diurno e noturno) forem iguais, a diferença entre elas seria nula (isto é o que é estipulado na $H_{0}$ );

- Então se $H_{0}$ for verdadeira, será que as médias das amostras seriam exatamente iguais? Como esperaríamos que elas se comportassem?

- Como vimos acima, os valores $\bar{X}$ tanto do noturno quanto do diurno variam de amostra para amostra. Portanto as diferenças ( $\bar{X}$ diurno - $\bar{X}$ noturno) variam de amostra para amostra (levando em conta diurno e noturno) e podem nos contar algo sobre as diferenças entre as verdadeiras médias (noturno-diurno). Então saber o comportamento dessa quantidade corresponde a conhecer a distribuição desta quantidade ( $\bar{X}$ diurno - $\bar{X}$ noturno). Este comportamento equivale ao conceito, já discutido, de distribuição amostral de ( $\bar{X}$ diurno - $\bar{X}$ noturno). É aqui o ponto crucial para uma Inferência Formal, já colocado acima - segundo Agresti e Franklin (2007): "Distribuição amostral é um conceito que os estudantes acham difícil de entender, e é crucial para seu entendimento de Inferência Estatística" (formal).

- RESULTADO TEÓRICO: Novamente invocando uma perspectiva simplificada, vamos considerar aqui que estamos trabalhando numa estrutura em que a distribuição normal seja apropriada, para ver quais os conceitos teriam ainda que ser inseridos para completar um raciocínio de Inferência Formal. Simplificando, de acordo com Magalhães e Lima (2011), temos 
Se $\bar{X}$ noturno (com n observações) tem distribuição normal com média $\mu$ (noturno) e desvio padrão $\sigma$ e se $\bar{X}$ diurno (com n observações) tem distribuição normal com média $\mu$ (diurno) e desvio padrão $\sigma$ (mesmo desvio para os dois grupos) então ( $\bar{X}$ diurno - $\bar{X}$ noturno) tem distribuição normal com média $[\mu($ diurno $)-\mu($ noturno $)]$ e desvio padrão $\sigma \sqrt{\frac{2}{n}}$. Na notação formal, temos $(\bar{X}$ diurno - $\bar{X}$ noturno $) \sim N\left[\mu(\right.$ diurno $)-\mu($ noturno $\left.) ; \sigma \sqrt{\frac{2}{n}}\right]$, e sob $H_{0}, N\left[0, \sigma \sqrt{\frac{2}{n}}\right]$.

Como se vê, ainda cstamos praticamente no meio do processo e a sofisticação aumenta a cada passo. Os alunos iniciantes ficam mergulhados na técnica pela técnica e, salvo exceções, não conseguem entender o percurso.

$4^{\mathrm{a}}$. Etapa: Interpretar a estatística do teste

As notas a serem analisadas foram obtidas de 25 alunos do Diurno e 25 alunos do Noturno da escola e estão a seguir:

\begin{tabular}{|c|ccccccccccccccccccccccccc|}
\hline noturno & 6 & 5 & 2 & 3 & 3 & 7 & 8 & 4 & 4 & 2 & 5 & 1 & 5 & 6 & 6 & 7 & 6 & 5 & 7 & 6 & 3 & 7 & 6 & 4 & 8 \\
\hline diurno & 7 & 3 & 4 & 6 & 5 & 9 & 8 & 6 & 5 & 9 & 3 & 7 & 8 & 4 & 10 & 7 & 8 & 5 & 7 & 9 & 6 & 9 & 6 & 10 & 7 \\
\hline
\end{tabular}

Tabela 6.1: Notas finais dos alunos

Obs.: $\mathrm{n}($ diurno $)=\mathrm{n}$ (noturno $)=25$, onde $\mathrm{n}$ é a notação usual para tamanho de amostra.

Vamos supor que no nosso caso $\sigma=2$ (isto nem sempre é conhecido - e então deverá ser estimado). Com o tamanho de amostra dado $(\mathrm{n}=25)$ é possível calcular a medida de variabilidade associada à diferença de médias, que será:

Desvio padrão $(\bar{X}$ diurno $-\bar{X}$ noturno $)=2 \sqrt{\frac{2}{25}}=0,56$.

As Figuras 6.1 e 6.2 mostram a distribuição de ( $\bar{X}$ diurno - $\bar{X}$ noturno) - normal - com média $[\mu($ diurno $)-\mu($ noturno $)]=0^{1}$ e desvio padrão 0,56 .

Os pontos assinalados, em ambas as figuras, como valor observado, seriam valores que poderiam ter sido encontrados nas diferenças das médias amostrais e cada um levaria a uma conclusão diferente. Assim, na Figura 6.1, o valor observado não seria muito provável de ser obtido caso essa distribuição fosse plausível - isso poderia sugerir a rejeição de $H_{0}$ em favor da hipótese alternativa $H_{a}$, já que, intuitivamente, o valor está se afastando do zero mais do que o "desejável". Já na Figura 6.2 , o valor observado estaria na região mais provável dessa distribuição e não sugere que a hipótese nula seja rejeitada em favor da hipótese alternativa.

Resumindo, de acordo com a teoria de teste de hipóteses, se $H_{0}$ for verdadeira a diferença deve se situar em torno do zero segundo o modelo das Figuras 6.1 (ou 6.2) e se essa a diferença for muito afastada de zero, numa zona de cauda à direita ou à esquerda, seria uma indicação de que a hipótese $H_{0}$ não é verdadeira e que Ha é mais plausível. Assim, se o valor observado para a diferença entre as médias amostrais estiver muito à direita ou muito à esquerda do zero, concluiríamos pela hipótese alternativa $H_{a}: \mu($ noturno $)-\mu($ diurno $) \neq 0$. Importante frisar que todas essas conclusões estão

\footnotetext{
${ }^{1 *} \mathrm{O}$ valor 0 corresponde à hipótese $H_{0}$ que estipula $[\mu($ diurno $)-\mu($ noturno $)]=0$
} 


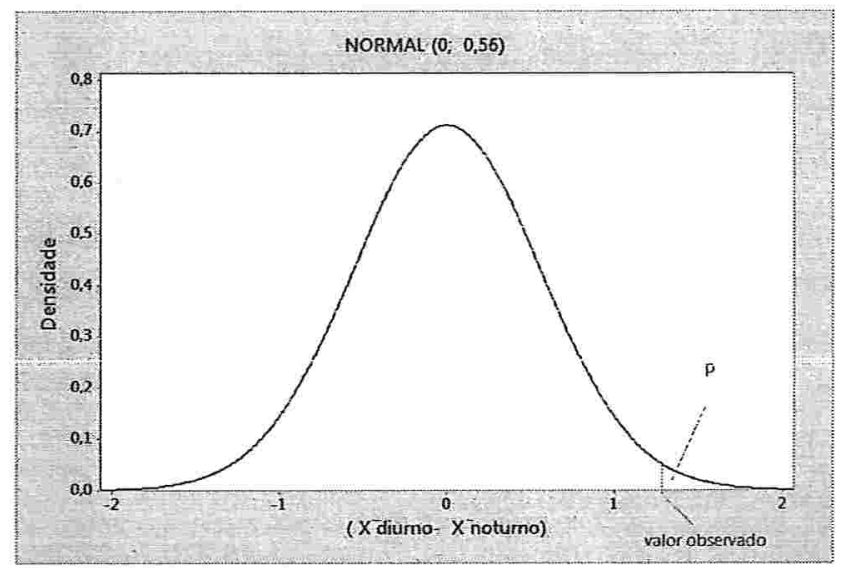

Figura 6.1: Curva Normal e Valor Observado

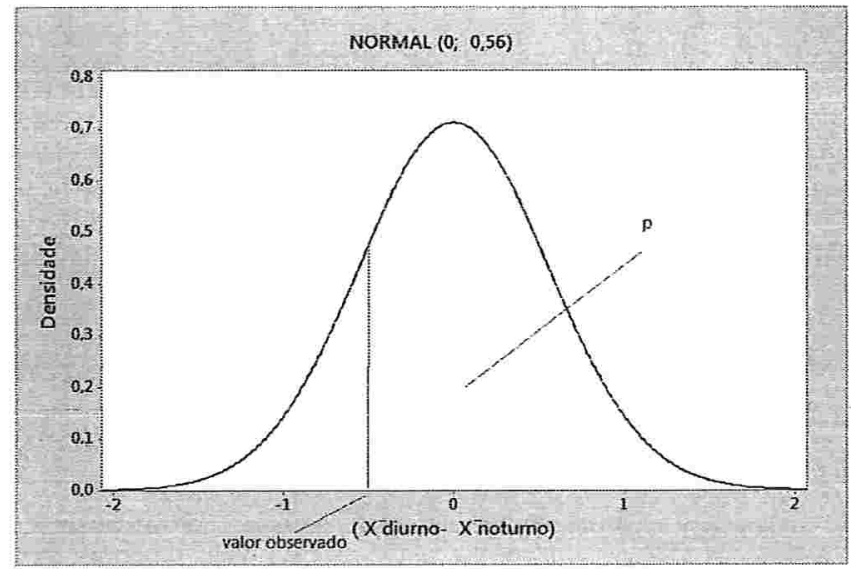

Figura 6.2: Curva Normal e Valor Observado

sujeitas aos chamados erros de tipo I e tipo II e embora não façamos aqui esta discussão o leitor interessado pode consultar Magalhães e Lima (2011).

$\mathrm{Na}$ verdade considerar este valor, ser ou não ser muito afastado, está ligado à probabilidade de se encontrar um valor igual a ele ou maior (em valor absolutio) no gráfico da distribuição. Mas novamente vem a questão: quanto é ser "muito" afastado? A curva foi construída levando em conta o valor da média na hipótese $H_{0}$ e o valor da medida de variabilidade associada à variável $(\bar{X}$ diurno - X Xoturno). Como partimos do pressuposto de que essa curva é normal, basta que se use uma. tabela da normal padrão (ou um aplicativo) para se calcular a área correspondente a cada região de interesse. Usando nossos dados já coletados, temos: $\bar{X}$ noturno $=5,04$ e $\bar{X}$ diurno $=6,72$ e a diferença entre as médias amostrais, que seria a Estatística do teste, tem o valor ( $\bar{X}$ diurno $-\bar{X}$ noturno $)=$ $6,72-5,04=1,68$.

Em termos do exemplo, trata-se de saber se 1,68 é "longe" ou "perto" de 0 , na distribuição das diferenças de médias ( $\bar{X}$ diurno - $\bar{X}$ noturno $) \sim N[0 ; 0,56]$. Em Estatística a distância é medida em número de desvios-padrão, o que corresponde a padronizar o valor 1,68 (no sentido de transformálo em um valor compatível, que possa ser comparado utilizando a normal de média zero e desvio 
padrão 1, para a qual as tabelas de probabilidade são construídas). Se tivermos um aplicativo que calcule as áreas da distribuição normal, então verifica-se dirctamente que este valor $(1,68)$ deixa uma área muito pequena à sua direita, correspondendo a uma área bem menor do que $1 \%$, sugerindo pela rejeição de $H_{0}$. A Figura 6.3 ilustra este fato.

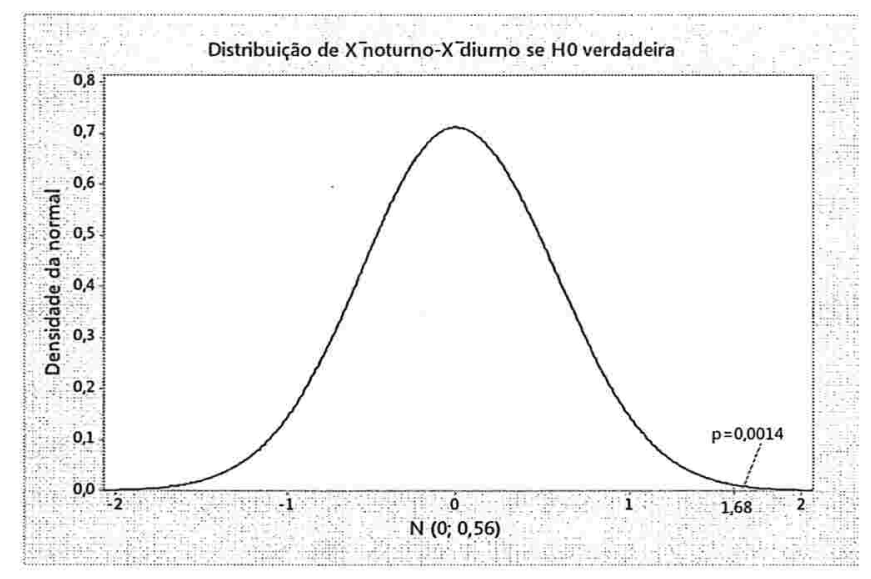

Figura 6.3: Probabilidade Associada ao Valor Observado

Caso tenhamos que usar a padronização para efeito do uso da tabela da normal padrão, de acordo com Magalhães e Lima (2011) temos:

Estatística do teste padronizada $=[(1,68-0) / 0,56]=3$

Isso mostra que 1,68 está a 3 desvios-padrão da média, o que na tabela da normal padrão corresponde a uma probabilidade de $0,0014(0,14 \%)$ de ser igual ou maior do que este valor. Isto significa que na distribuição original das diferenças de médias, se a hipótese de igualdade de médias fosse verdadeira, a diferença encontrada estaria a 3 desvios padrão da média, o que configura um valor extremo, sugerindo que a hipótese nula deve ser rejeitada.

O nível descritivo não foi definido formalmente e nem usado do modo corrente (ou seja, duplicado para o caso de hipótese alternativa bi-caudal). Mas sua apresentação foi no espírito de aproximar o raciocínio para uma futura abordagem desse tópico.

\section{$5^{\text {a }}$. Etapa - Apresentar a conclusão}

Já vimos que para responder à indagação do secretário de educação, sobre a comparação de aprendizagem de alunos do diurno e noturno, o diretor da escola fez uma simplificação, propondo o uso de notas de Matemática para este propósito, usando duas salas de $3^{\circ}$. ano de ensino médio. Com o intuito de mostrar a complexidade do problema para uma primeira abordagem na escola básica, procedeu-se à construção de um teste de hipótese de comparação de médias, usando como estatística a diferença de médias observadas.

Muitas premissas foram colocadas no intuito de poder aplicar a teoria exposta e o leitor deve ficar atento que esta simplificação não é possível de ser usada na maioria dos casos. Mas o raciocínio 
é que está em pauta, para mostrar obstáculos em diversos pontos do uso da técnica.

A partir dos dados observados com classes de 25 alunos e levando em conta as suposições feitas e as simplificações propostas, há motivos para rejeitar a hipótese $H_{0}$ de que as médias de Matemática sejam iguais nos dois períodos. Ou seja, e se for plausível que o estudo das médias reflita a aprendizagem, o resultado significa que há indícios de diferença na aprendizagem entre os dois turnos. É importante lembrar que esta conclusão tem um erro de $0,14 \%$ que é a probabilidade de essa diferença encontrada pertencer à Normal $(0 ; 0,56)$, obtida a partir da suposição de $H_{0}$ ser verdadeira.

A partir dessas etapas pode-se ver o peso da teoria (mesmo com premissas simplificadas) para uma primeira abordagem inferencial, quer seja no nível básico, quer seja nos cursos introdutórios de Estatística do nível superior.

\subsubsection{Principais Dificuldades Relacionadas à Abordagem Formal}

Batanero et al. (2011) ressaltam que uma das dificuldades comuns observadas em uma análise formal está relacionada a discernir as situações em que uma hipótese pode ser falsa ou não. Para verificar a validade de uma hipótese é necessário traduzir a situação em números para que possam ser comparados. Para isso são criadas regras de decisão que são confrontadas com valores extraídos dos dados e, de acordo com a força das evidências desses valores, as conclusões são apresentadas.

Harradine et al. (2011) relatam que o início das pesquisas em Educação Estatística relacionadas ao raciocínio inferencial começaram na última década de oitenta. Por meio delas foi detectado que muitas pessoas não seguem as regras matemáticas nem os procedimentos formais para se tomar decisões em situações de incerteza. Ao contrário do que se espera, essas pessoas se apoiam na experiência comum que, por vezes, acabam conduzindo a erros sistemáticos. Este comportamento se contrapõe à utilização de uma estrutura formal para tomada de decisão.

De acordo com os mesmos autores, o entendimento da variação de uma estatística, ou seja, do valor obtido por um estimador, é o elemento central no aprendizado e utilização da Inferência Estatística e está totalmente ligado ao conceito de distribuição amostral.

A compreensão da distribuição amostral é considerada, como já vimos, um divisor de águas no desenvolvimento dos conceitos estatísticos e responsável por alguns dos erros conceituais mais frequentes, dificultando a compreensão dos alunos sobre o processo de Inferência Formal.

Harradine et al. (2011) dividem o processo de Inferência Estatística em três partes interdependentes e relacionadas entre si, que são: (a) raciocínio; (b) conceito; (c) cálculos e chamam a atenção para o fato de, ao realizar um teste de hipótese, muitos cálculos podem ser obtidos por meio de recursos computacionais ou de forma algorítmica pelos alunos. Citam também que as principais dificuldades quanto aos testes de hipóteses estão relacionadas com os dois primeiros tópicos citados.

Tratando do exemplo em questão, as notas do período diurno são consideradas independentes das notas do noturno, ou seja, a nota de um aluno do período diurno não influencia qualquer nota do período noturno e vice versa. Assim, temos uma situação na qual as amostras são independentes, de mesmo tamanho, e com a suposição de variâncias conhecidas e iguais. Mais uma vez enfatizamos que essas suposições iniciais acabam por simplificar e reduzir o aparato teórico necessário para realização do teste, uma vez que também foi assumido que as variáveis nota diurno e nota do noturno seguem o modelo de distribuição normal. Outras situações são possíveis de acordo com as suposições iniciais e a disponibilidade das informações em cada situação. 
Percebe-se então um arcabouço teórico construído para dar uma resposta (ainda que com margem de erro) à questão proposta e que além do uso da lógica formal ainda tem muitas premissas a serem colocadas para legitimar o processo. A aprendizagem não pode começar como uma teoria imposta, pois se parece mais com um processo que se apropria lentamente do raciocínio estatístico, para conduzir os alunos a tirarem suas conclusões a partir da "interiorização" dos conceitos de variabilidade e incerteza.

Em vista dessas dificuldades, vamos apresentar na próxima seção as ideias de abordar este problema por meio da Inferência Informal, o que representaria o primeiro contato dos alunos com análise desta natureza, procurando remover obstáculos que impedem a compreensão do assunto, ao preço de não tentar dar respostas supostamente definitivas (o que evidentemente nem a teoria formal o faz).

\subsection{Comparação Entre Dois Grupos - Uso de Inferência Informal}

Os aspectos teóricos referentes à estrutura lógica dos testes de hipóteses e as dificuldades encontradas pelos alunos na interpretação dos resultados da Inferência Formal têm intensificado a discussão entre educadores da área sobre os métodos de ensino relacionados a essa área do conhecimento.

Entre os problemas levantados por Batanero et al. (2011), destacamos a utilização de argumentos estatísticos para sustentar conclusões sem se dar conta que esses argumentos, por si só, as vezes não são suficientes para sustentá-las. A incerteza inerente aos testes de hipóteses, e também a outras possibilidades que a Estatística oferece, ocasionam erros conceituais que, segundo a autora, conduzem a generalizações inadequadas e a falta de instrumentos alternativos para se concluir sob situações de incerteza.

No exemplo de Inferência Formal oferecido na seção anterior, o arcabouço com as suposições colocadas pode ser irreal, comprometendo a expectativa da força de conclusão esperada (mesmo considerando a margem de erro). Como nosso intuito era abordar as dificuldades técnicas da teoria envolvida, esse caminho foi o escolhido naquele momento.

Watson e Moritz (1999) comentam que a abordagem formal exige um rigor quanto à linguagem, sendo necessário domínio dos conceitos básicos. No início, ao comparar dois grupos, alguns alunos tendem a mesclar sua própria intuição natural e o conhecimento estatístico, relacionando-os para criar estratégias de comparação entre os grupos, e isto não é aceito na abordagem formal clássica.

Um aspecto que pode dificultar a compreensão dos procedimentos formais é a maneira como os conteúdos são apresentados nas aulas. Segundo Lingyuan et al. (2004), os professores ocidentais, de uma maneira geral, tendem a enfatizar em suas aulas aspectos fragmentados relacionados aos procedimentos formais e mecanização de cálculos, e isto ocasiona dificuldades na compreensão do problema como um todo. Já os professores chineses e japoneses enfatizam o entendimento dos conceitos por meio de poucos problemas que abordam diversos conceitos.

Pfannkuch et al. (2010) também destacam que comparar grupos é muito relevante como ferramenta pedagógica pois depende, mesmo que de maneira rudimentar ou informal, da utilização de conceitos fundamentais da Estatística e que são necessários e indispensáveis para o desenvolvimento da Inferência Formal. Para isso é necessário utilizar, inicialmente de maneira superficial, uma linguagem adequada à compreensão do aluno. A introdução dos termos precisa ser gradativa para 
facilitar a compreensão e o entendimento dos assuntos relacionados. Os autores comentam ainda que, dentro do ensino de Estatística, a abordagem informal estimula a utilização de recursos visuais junto a estratégias numéricas, contribuindo para o desenvolvimento de bons hábitos tanto para a análise exploratória de dados no ensino básico quanto para o desenvolvimento da Inferência Formal.

Com outras palavras, o ensino de Estatística que segue essa abordagem precisa ter uma dupla função: fornecer conhecimento mínimo para o aluno para compreender o mundo como cidadão e também para compreender os métodos formais caso necessite deles quando ingressar no nível superior ou até mesmo no mercado de trabalho que exija tal conhecimento.

Vamos então abordar o mesmo problema visto na seção anterior sob a ótica da Inferência Informal. A situação proposta sobre a aprendizagem foi simplificada na seção anterior, na discussão da Inferência Formal, e resultou na seguinte pergunta: "As notas finais em Matemática dos alunos do período diumo são diferentes das notas finais em Matemática dos alunos do período noturno?". Esta formulação será analisada em um dos tópicos da análise da Inferência Informal.

Os dados coletados são repetidos a seguir para facilitar a consulta dos mesmos ao longo dessa seção, a saber:

\begin{tabular}{|c|ccccccccccccccccccccccccc|}
\hline noturno & 6 & 5 & 2 & 3 & 3 & 7 & 8 & 4 & 4 & 2 & 5 & 1 & 5 & 6 & 6 & 7 & 6 & 5 & 7 & 6 & 3 & 7 & 6 & 4 & 8 \\
\hline diurno & 7 & 3 & 4 & 6 & 5 & 9 & 8 & 6 & 5 & 9 & 3 & 7 & 8 & 4 & 10 & 7 & 8 & 5 & 7 & 9 & 6 & 9 & 6 & 10 & 7 \\
\hline
\end{tabular}

Tabela 6.2: Notas finais dos alunos

Observe que as classes têm igual tamanho de amostra para diurno e noturno, ou seja, 25 alunos em cada classe. Amostras com mesmo tamanho, de acordo com Pfannkuch e Horton (2009), são mais indicadas nas primeiras abordagens.

Para exemplificar algumas das considerações anteriores e destacar alguns aspectos relacionados à análise exploratória de dados e à Inferência Informal vamos seguir as etapas descritas por Pfannkuch e Horton (2009), no guia para raciocínio comparativo, seguindo o raciocínio informal. Os autores sublinham que o guia não é para orientar alunos e sim professores, pois não se trata de atividades a serem propostas em sala de aula. Ele descreve processos do pensamento estatístico para reflexão dos professores em seu preparo para o ensino da Estatística.

Nele são descritas as principais etapas que os estudantes percorrem durante o processo de pensamento estatístico que utilizam quando realizam análises de medidas descritivas, do gráfico de pontos e de caixas, para comparar duas amostras. Essas etapas são as mesmas para qualquer análise informal sendo que cada uma delas pode ser abordada em níveis diferentes, de acordo com o conhecimento dos alunos.

Em Pfannkuch e Horton (2009) são destacados aos professores alguns elementos educacionais que precisam ser desenvolvidos pelo professor em todas as etapas da comparação entre dois grupos. Para que a aprendizagem ocorra de acordo com as premissas da Inferência Informal que orientam o ensino da Estatística é importante que o professor:

1) Mostre o que olhar e o que comentar a cada momento da análise, seja ela gráfica ou numérica;

2) Enfatize a diferença entre o que é amostral (particular) e o que pode ser estendido à população (generalização); 
3) Mostre que qualquer medida analisada isoladamente das outras não é suficiente para fazer afirmações mais abrangentes e também não podem ser extrapoladas para população;

4) Ilustre, por meio de exemplos, como proceder em cada uma das etapas que compõe a comparação entre dois grupos.

De acordo com esses autores, para desenvolver inicialmente os conceitos estatísticos, é necessário uma comparação visual utilizando gráficos e observando deslocamentos entre as amostras bem como características comuns e distintas entre elas. Nesse sentido, para distinguir as características observadas na amostra das características que se espera encontrar na população, é necessário utilizar cuidadosamente a linguagem.

De acordo com Pfannkuch e Horton (2009), para se referir às características amostrais os termos mais utilizados e que refletem a distinção entre a amostra e a população são: "eu observo que...", "eu percebo que...", "a amostra revela que... " já os pensamentos inferenciais, que manifestam suposições sobre a população de acordo com a análise da(s) amostra(s), são precedidos de termos como "eu espero que...", "é possível que...", "isso pode ocorrer na população pois..."ou semelhantes.

O uso repetitivo de alguns termos do parágrafo anterior é esperado e necessário quando se utiliza o raciocínio inferencial para comparar duas amostras. Isso é útil e necessário para distinguir claramente o que se observa na amostra do que se espera encontrar na população, pois contribui para fixar as ideias e conceitos relativos à Inferência Informal ao mesmo tempo em que reforça o que é observado na amostra e o que é inferido.

No exemplo a seguir, procurou-se destacar quais observações são relevantes a se fazer quando se pretende comparar amostras, quais aspectos observar e como confrontá-los e obter informações a partir disso. Além disso, buscou-se mostrar claramente ao longo do desenvolvimento do texto que medidas analisadas isoladamente não são suficientes para fazer afirmações sobre a população desdobrando o processo de pensamento estatístico envolvido nessa análise.

Pfannkuch e Horton (2009) dividem didaticamente a comparação em:

- Levantamento de um problema;

- Elaboração de uma questão inicial;

- Elaboração de uma questão investigativa;

- Elaborar um critério numérico para responder a questão investigativa;

- Coleta dos dados;

- Comparação não numérica - Organização dos dados em dispositivos gráficos - Gráfico de Pontos e Gráfico de Caixas;

- Comparação numérica - Tabulação dos dados - Medidas Descritivas;

- Confronto das observações realizadas por meio dos dispositivos gráficos e por meio das medidas descritivas;

- Conclusão. 
Diante da estrutura proposta pelos autores, será então analisada, agora sob a perspectiva da Inferência Informal, a mesma situação desenvolvida na seção anterior por meio da Inferência Formal.

- Levantamento de um problema

Um secretário de educação gostaria comparar o rendimento (aprendizagem) dos alunos do diurno com o dos alunos do noturno e pediu a um diretor de escola pública da cidade para fazer esta verificação.

- Elaboração de uma questão inicial

Uma questão que traduz o problema inicial poderia ser: o rendimento (aprendizagem) dos alunos do diurno é diferente dos alunos do noturno? Pfannkuch e Horton (2009) destacam que a questão inicial está sujeita a alterações para que seja possível utilizar observações a serem coletadas. Geralmente as questões iniciais são mais abrangentes pois fazem referência a uma população.

- Elaboração de uma questão investigativa

A questão investigativa é uma etapa muito importante na qual o aluno utiliza o conhecimento acumulado. Ela poderia variar de aluno para aluno mesmo que estes apresentem o mesmo nível de letramento estatístico. De acordo com Pfannkuch e Horton (2009) a questão investigativa é um refinamento da questão inicial, ou seja, a questão investigativa contém restrições sobre a questão inicial que consideram as limitações impostas para obtenção da amostra. Nesse caso, algumas das restrições que encontramos são:

- Definir, com a precisão possível, o que é rendimento escolar;

- Escolher uma maneira de representar esse rendimento por meio dos dados coletados;

- Coletar dados suficientemente abrangentes para responder a questão inicial.

Na seção 6.1 foi feita uma discussão que precedeu a análise formal e que continuou na $1^{\mathrm{a}}$ etapa sobre a questão de trabalho. Assim é possível e desejável em ambas as análises (formal e informal) discutir essa escolha da melhor pergunta, mas temos claro que os livros-texto da escola básica geralmente evitam estas discussões.

Aproveitamos então as colocações feitas na seção 6.1 e nos orientaremos pela questão: "As notas finais em Matemática dos alunos do pcríodo diumo são diferentes das notas finais em Matemática dos alunos do período noturno?"

Com isso pretende-se, a partir de conclusões feitas sobre a questão investigativa, ou seja, sobre a amostra, possibilitar algumas inferências sobre a questão de interesse, ou seja, sobre a população.

- Elaborar um critério numérico para responder a questão investigativa

Esse é um momento importante para o desenvolvimento do pensamento estatístico. A escolha de um critério numérico implica em conectar informações de dois mundos, o mundo real e sua constituição subjetiva com o mundo numérico revelado pela amostra. Essa tradução é uma tarefa difícil nas primeiras vezes. Executá-la é um processo gradativo que pode ser comparado à tradução 
entre dois idiomas, o que se conhece e o que se está aprendendo. Por isso esse momento pode ser considerado um obstáculo para alguns alunos.

De certa forma, a escolha de um critério numérico é arbitrária, porém em alguns casos não existem muitas opções de medidas para representar aspectos que se deseja verificar. Esse momento do desenvolvimento de uma análise informal pode ser relacionado com a definição das hipóteses nula e alternativa para uma análise formal, o que corresponde à $2^{\mathrm{a}}$ etapa, como com a identificação da estatística do teste, correspondente à $3^{\mathrm{a}}$ etapa. Assim, a média poderá ser proposta como critério numérico de referência para comparação entre grupos.

Nessa situação, podemos considerar que o aproveitamento dos alunos nos dois períodos de sua escola possa ser representado utilizando a média das notas finais dos alunos. É necessário que o professor comente sobre as dificuldades teóricas que se tem para quantificar o conhecimento dos alunos e comparar seus aproveitamentos, uma vez que essa quantificação é pauta na discussão de muitos estudiosos.

Após escolher a média como medida de posição, podemos dar continuidade à análise exploratória de dados, considerando a elaboração prévia de um plano para coleta. Antes de iniciar uma pesquisa, além dos passos já discutidos até agora, é necessário pensar se é factível e como, quando, onde e quantos dados serão coletados. Envolver os alunos com estas questões sobre a elaboração do plano é fundamental, mesmo que isso demande algum tempo para acontecer, o aluno iniciante desconhece a importância desses passos e só desta forma a análise começa a fazer sentido para ele.

- Coleta dos dados

De acordo com Pfannkuch e Horton (2009), essa etapa demanda uma cuidadosa discussão com os alunos para que eles percebam as influências de uma boa amostra na obtenção de informações relevantes.

É importante elaborar uma cuidadosa coleta de dados para produzir uma amostra representativa. Entre as principais recomendações está a aleatorização do processo de coleta de dados.

Quanto mais dados se coleta mais cuidados são necessários e mais custos são dispendidos. Verificar se existem diferenças entre o desempenho escolar dos alunos dos dois períodos é uma questão abrangente que pode ser verificada em nível nacional, com uma coleta de dados igualmente em nível nacional ou em outras escalas de abrangência. Nesse exemplo, a coleta de dados ficará restrita a uma escala bem menor e serão utilizados os dados coletados unicamente em uma única escola conforme restringido durante a elaboração da questão investigativa.

Nesse momento o aluno pode perceber claramente as restrições impostas pelo refinamento da questão inicial bem como as limitações que essa acarreta nas conclusões e a necessidade de se deduzir sobre o geral (população) observando o particular (amostra). Essa é a essência da Inferência Estatística que trabalha com a incerteza.

Um bom exercício é fazer uma reflexão sobre a representatividade de uma amostra. Seria bom se a amostra contivesse o menor número de elementos possível e ao mesmo tempo apresentasse todas as características da população. Sabemos que na prática, quase nunca é possível obter uma amostra com todas as características populacionais, mas os alunos ao planejarem coletar tal amostra certamente desenvolverão uma noção tanto da representatividade como da variabilidade da amostra, o que é considerado um conceito fundamental. 
Essa reflexão contribui para o desenvolvimento do letramento estatístico e favorece também a noção de distribuição amostral, um dos principais obstáculos encontrados por alunos que estudam Estatística. A discussão do que é uma amostra representativa e o que é razoável assumir ou não quanto aos dados coletados não será apresentada aqui, mas pode ser consultado em Magalhães e Lima (2011).

- Comparação não numérica - Organização dos dados em dispositivos gráficos - Gráfico de Pontos c Gráfico de Caixas

Começar uma análise utilizando gráficos é um excelente ponto de partida para se comparar dois grupos. Pfannkuch e Horton (2009) sugerem iniciar por meio de uma análise visual (e chamada por eles de análise não numérica), utilizando o gráfico de pontos e o gráfico de caixas. A escolha desses dois gráficos já foi comentada quando da apresentação das Figuras 6.4 e 6.5.

Os autores orientam utilizar como ponto de partida da análise visual a observação de três aspectos: os pontos que se sobrepõem; os pontos que não estão sobrepostos, ou seja, os deslocamentos; aspectos incomuns e/ou pontos discrepantes. Essa primeira visualização mais geral desperta intuitivamente algumas percepções nos alunos.

Em seguida é necessária uma comparação e descrição mais detalhada e orientada pelos conceitos fundamentais que os alunos trazem consigo. Nessa descrição os alunos precisam incluir elementos que observam nos gráficos tais como medidas resumo e, se necessário, observações pontuais sobre valores específicos. Nesse momento surgem afirmações contendo "eu espero que...", "é possível que...", "eu observo que...".

Toda constatação por meio da análise-dos dados pode ser considerada interpretação dos dados e comparada à $4^{\mathrm{a}}$ etapa da análise formal. Nesse etapa a estatística utilizada na análise formal é comparada ao comportamento esperado da curva de uma distribuição de probabilidade.

Cada tipo de gráfico é mais sensível a um certo aspecto, revelando características antes não percebidas por outros meios. Para obter informações sobre o comportamento da amostra, o gráfico de pontos explicita esse comportamento, pois observa-se individualmente cada dado. Assim, observando cada tipo de gráfico, buscam-se evidências, padrões, tendências e outras informações.

\section{Dot Plot - Gráfico de Pontos}

A partir dos dados, tabulados no início da seção, foram construídos dois gráficos de pontos sobre um mesmo eixo horizontal, o que facilita a comparação.

A vantagem desse tipo de gráfico é que ele preserva a ideia de grupo, mesmo mostrando individualmente cada valor. Também fornece um esboço do comportamento da amostra o que pode ser relevante quando se pretende saber sobre a distribuição da população que forneceu os dados.

Os autores ainda comentam que os gráficos, quando apresentados em uma mesma escala, facilitam a comparação entre os grupos, mesmo quando estes grupos têm tamanhos diferentes.

Outra vantagem é a possibilidade de ver algumas características dessa amostra como, por exemplo, moda, simetria, subgrupos, tendências padrões, etc.

O gráfico acima sugere que as notas do período diurno tendem a ser maiores que as notas do período noturno (consideradas como grupo). De acordo com Pfannkuch e Horton (2009), nesse contexto, a palavra "tende" significa que as notas do período diurno estão deslocadas em relação às 
notas do período noturno porém, isso não significa uma completa separação entre as duas amostras e muito menos uma completa separação entre as duas populações.

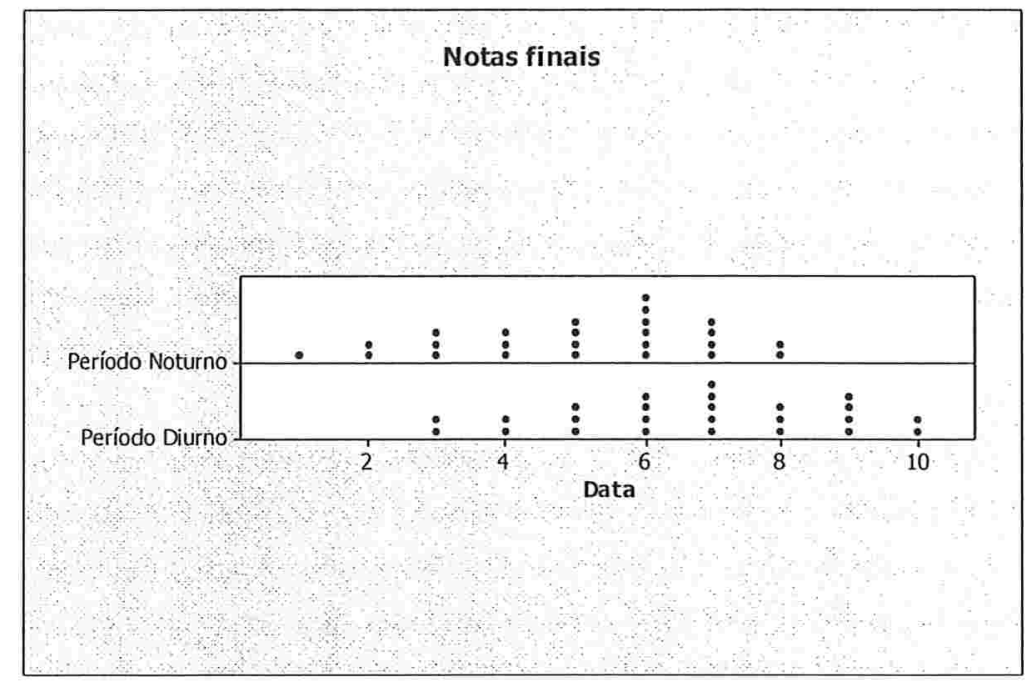

Figura 6.4: Gráfico de Pontos

Isso não implica que a média ou a mediana do período diurno sejam maiores que as do período noturno. A palavra "tende" é utilizada no sentido descrever ou comparar as duas amostras quanto ao seu deslocamento visual e representa uma primeira impressão sem utilização das medidas descritivas.

Além disso, outras comparações podem ser feitas entre as amostras e dentro de cada amostra. Nas comparações entre as amostras é possível verificar sobreposições, deslocamento, variabilidade e aspectos relacionados ao formato do gráfico dos valores amostrados (simetria, crescimento, decrescimento, etc.). Na comparação dentro de cada amostra, é possível verificar se existem características únicas de cada amostra, como por exemplo, valores discrepantes.

Assim, observando ainda o gráfico de pontos acima, além do deslocamento entre as amostras já mencionado, é possível verificar aspectos sobre a variabilidade dos dados por meio da amplitude. Para o período noturno a amplitude é 7 e para o período diurno a amplitude é 7 . Como são iguais, é coerente cogitar uma variabilidade semelhante entre os dois grupos.

A amplitude é uma medida útil para descrever variabilidade e muito fácil de ser ensinada em sala de aula. Começar uma discussão com ela é uma boa tática. No entanto, segundo o já mencionado guia norteador dessa análise, utilizar unicamente a amplitude para fazer afirmações sobre a variabilidade não é recomendado pois essa medida não é robusta, uma vez que é fortemente influenciada por valor discrepante no conjunto de dados. Como não se observa nenhum valor discrepante nas amostras em questão podemos dizer que a variabilidade entre as amostras parece semelhante e esperamos, considerando essa percepção, que a variabilidade populacional também seja semelhante.

O gráfico de pontos permite também visualizar uma semelhança quanto à forma como os pontos estão distribuídos. Ambos possuem maior concentração dos dados na região central e menor concentração nas regiões extremas, ou seja, caudas mais finas. A análise visual não revela simetria absoluta entre as duas amostras o que pode sugerir que também não haja simetria entre os dados 
populacionais.

Como já visto, não existem pontos discrepantes nem percebe-se qualquer outra característica exclusiva de uma ou outra amostra. Também não foi observado saltos entre os valores amostrais, ou seja, não existem lacunas entre os valores observados.

Na literatura, mesmo em textos escritos em português, muitas vezes se emprega o termo "outlier" para se referir aos valores discrepantes (no sentido de serem isolados, muito afastados dos demais). Pfannkuch e Horton (2009) chamam a atenção para o uso correto desse termo, independente da língua na qual é escrito. Alguns alunos usam o termo como um jargão para rotular valores muito grandes ou muito pequenos sem considerar o seu significado. Para ser considerado discrepante um valor precisa estar além ou aquém de certos limites estabelecidos. Às vezes eles estão corretos e ajudam a esclarecer certo comportamento da população, mas às vezes, são registros incorretos e, quando possível, os autores recomendam que os valores discrepantes sejam checados para verificar se não existiu algum tipo de erro na coleta.

Ben Zvi e Garfield (2004) alertam que, nos primeiros contatos com os gráficos de pontos, ou qualquer outro tipo de gráfico, é esperado que os alunos não saibam extrair todas as informações possiveis nem todos os significados das informações extraídas. Assim, cabe ao professor reforçar certas características ao realizar a análise dos dados para que os alunos percebam, por meio do exemplo prático, o tipo de pensamento utilizado e façam por si mesmos as análises necessárias, utilizando um certo grau de analogia.

Não se trata de condicionar os alunos a repetirem o que observaram, mas sim de oferecer a possibilidade de utilizarem o que observaram como uma referência, um roteiro para que eles possam realizar as análises necessárias. $\mathrm{O}$ uso de mais de um tipo de recurso visual pode auxiliar na construção e elaboração de hipóteses ou argumentos antes não percebidos por meio de um único recurso.

\section{Box Plot - Gráfico de Caixas}

Conforme detalhado no Capítulo 2, o gráfico do tipo box plot ou gráfico de caixas transmite algumas informações importantes para análise exploratória de dados uma vez que é construído a partir de algumas medidas descritivas. Utilizando uma mesma escala, obtemos a Figura 6.4 que apresenta os box plots (gráfico de caixas) dos dois grupos de notas. A Figura 6.5 apresenta os box plots tendo sobrepostos os valores individuais que seriam os pontos dos dot plots (gráfico de pontos) já apresentados. Pfannkuch e Horton (2009) ressaltam a impropriedade do uso de gráfico de caixas com um número pequeno de observações, chegando a sugerir que haja pelo menos 15 observações para que o mesmo seja construído.

A partir da Figura 6.5, percebe-se um deslocamento de posição entre as duas caixas, característica já percebida por meio do gráfico de pontos. Assim, conforme já verificado pela análise do gráfico de pontos, percebe-se que as notas do período diurno tendem a ser maiores que as notas do período noturno. Os componentes que constituem esse gráfico como os quartis, mediana, máximo c mínimo também serão analisados a seguir para a comparação dos grupos. Utilizando o gráfico apresentado também é possível verificar a amplitude dos valores, intervalo interquartil - IQ, o valor máximo e mínimo de cada amostra. Todas essas verificações conduzem aos mesmos resultados que as verificações feitas anteriormente por meio do gráfico de pontos e das medidas descritivas c por isso não serão repetidas. 


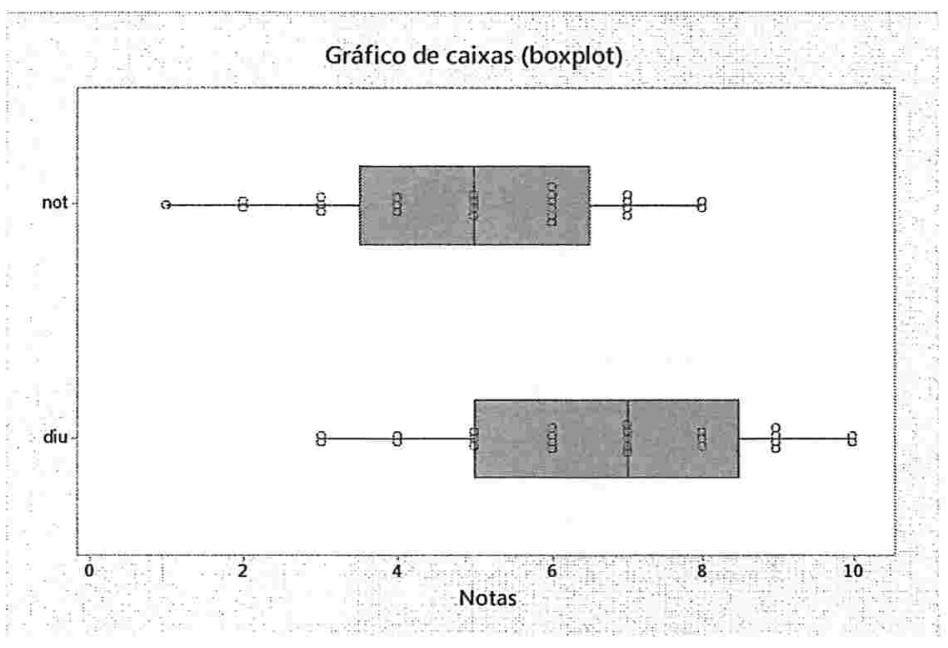

Figura 6.5: Gráfico de Caixas (Box Plot) com Gráfico de Pontos Sobreposto

Comparando os tamanhos das caixas dos dois períodos pode-se dizer que são, visualmente, de tamanhos diferentes, pois a segunda caixa, referente aos dados do período diurno, é ligeiramente maior, ou seja, apresenta um intervalo interquartil maior. Isso pode sugerir que, de acordo com a análise visual das caixas, a variabilidade entre os dados do período diurno seja ligeiramente maior do que a variabilidade entre os dados do período noturno (mas é sutil, além da indicação já vista de mesma amplitude dos dois grupos).

Percebe-se que a haste superior da caixa referente ao período diurno está totalmente acima da haste superior da caixa referente ao período noturno. Isso mostra que os $25 \%$ maiores valores do período diurno são todos maiores ou iguais ao maior valor encontrado no período noturno.

Ao verificar a mediana da caixa referente ao período diurno percebe-se que o $Q_{3}$ da caixa referente ao período noturno está abaixo dela. Em outras palavras, $75 \%$ dos valores das notas do período noturno estão abaixo da mediana do período diurno:

\section{- Comparação numérica - Tabulação dos dados - Medidas Descritivas}

No início da seção, apresentamos uma organização dos dados brutos já ordenados. Em seguida à obtenção dos dados, além das representações visuais que se podem obter a partir deles, é esperado um resumo dos dados por meio de medidas descritivas. Esse procedimento visa extrair algum tipo de informação dos dados que irão corroborar ou complementar as informações obtidas a partir dos gráficos.

Neste ponto, de cálculos de estatísticas descritivas, as abordagens tradicionais de textos ou de sala de aula valorizam os cálculos e as técnicas destinando um tempo excessivo com contas e diminuindo o tempo disponível para reflexão, para construção dos significados e das relações entre as medidas resumo. Como resultado desse tipo de abordagem, alguns alunos se tornam aptos com relação aos cálculos, mas nem sempre sabem seu significado nem tampouco sua relação com as características amostrais. Outros alunos simplesmente abandonam, pois tendo dificuldades com os cálculos nem chegam a questionar seu significado. 
A partir dos dados brutos obtemos as medidas descritivas, calculadas para $n=25$, (neste trabalho o desvio padrão está sendo calculado com $n$ no denominador) apresentadas na Tabela 6.3:

\begin{tabular}{|c|c|c|}
\hline \multicolumn{3}{|c|}{ Notas finais } \\
\hline & Noturno & Diurno \\
\hline Média amostral & 5,04 & 6,72 \\
\hline Primeiro quartil $Q_{1}$ & 3,50 & 5,00 \\
\hline Mediana amostral & 5,00 & 7,00 \\
\hline Terceiro quartil $Q_{3}$ & 6,50 & 8,50 \\
\hline Desvio padrão amostral & 1,89 & 2,01 \\
\hline Amplitude amostral & 7,00 & 7,00 \\
\hline Maior valor amostral & 8,00 & 10,0 \\
\hline Menor valor amostral & 1,00 & 3,00 \\
\hline
\end{tabular}

Tabela 6.3: Medidas Resumo

Com as medidas descritivas em mãos é possível comparar numericamente diversos aspectos de uma amostra. Uma das possibilidades iniciais é comparar cada medida uma a uma.

Ao analisar a Tabela 6.3, verifica-se que a média amostral, o primeiro quartil, a mediana e o terceiro quartil apresentam valores maiores para as notas do período diurno. Isso vai na mesma linha já sugerida de um deslocamento entre as medidas no sentido de que os valores nas notas do período diurno tendem a ser maiores do que as notas do período noturno.

A variabilidade pode ser medida, como mencionado anteriormente, pela amplitude. Mas há outras possibilidades, já apresentadas e discutidas no Capítulo 2, que são o IQ ( $3^{\circ}$ Quartil - $1^{\circ}$ Quartil) e o desvio padrão.

Para este último, o valor para o período diurno é 2,01 e para o período noturno é dada por 1,89. Assim, constata-se que o desvio padrão do período diurno tem valor superior ao do período noturno, fato que aponta para a mesma situação que a descrita anteriormente.

Já o intervalo interquartil descreve uma variabilidade "centralizada" e, para o período diurno temos IQD $=3,50$ e para o período noturno, IQN $=3,00$. Segundo essa medida, a variabilidade é maior para a amostra do período diurno. Vemos que as medidas de variabilidade sugerem a mesma coisa: pouco maior no diurno. Diante disso pode-se conjecturar que o mesmo ocorra com os dados da população embora não exista, até esse momento, alguma evidência que garanta qualquer conclusão acerca da variabilidade.

Levando em conta os valores dos quartis, temos que $75 \%$ das notas do período diurno são menores ou iguais a 8,50 e $75 \%$ das notas do período noturno são menores ou iguais a 6,50.

$\mathrm{Na}$ tabela das medidas descritivas é possível verificar uma proximidade numérica entre os valores de média e mediana nos dois períodos. Conforme mencionado, essa evidência numérica sugere uma simetria entre ambos os comportamentos dos dados. Além disso ambos os grupos apresentam semelhança no que se refere a uma maior concentração dos dados na região central e uma menor concentração dos dados nas caudas.

Quanto à distribuição dos dados, ambas distribuições não são perfeitamente simétricas, ou seja, não há correspondência de posição, de forma ou de medida em relação aos eixos do gráfico. Elas apresentam semelhança, conforme mencionado, no que se refere a uma maior concentração dos dados da região central e uma menor concentração dos dados nas caudas. 
Em alguns casos existe mais de uma maneira de se obter as mesmas informações. Em algumas situações na análise exploratória de dados, isso também ocorre. Embora pareça redundante constatar a mesma coisa utilizando diferentes meios, é necessário mostrar aos alunos as várias possibilidades para que escolham e utilizem os recursos mais adequados às situações em que estão trabalhando, além de reforçar os conceitos e ideias envolvidas sob diversos aspectos.

- Confronto das observações realizadas por meio dos dispositivos gráficos e por meio das medidas descritivas

Uma das maneiras de se verificar a coerência do que foi revelado pela análise dos gráficos e das medidas descritivas é confrontar as conclusões obtidas por meio de cada recurso. Por exemplo, o gráfico de pontos revelou ligeiramente valores maiores para o período diurno, então o passo seguinte é verificar se esse comportamento dos dados também seja percebido na análise do gráfico de caixas e das medidas descritivas.

Caso haja alguma divergência entre o que foi percebido nas diferentes abordagens é necessária uma análise mais cuidadosa. Porém, para concluir algo é necessário lembrar que a amostra considerada representa apenas os alunos de duas classes, sendo uma de cada período; essa conclusão, portanto, se restringe a essa amostra.

Considerando a divisão em etapas feitas por Pfannkuch e Horton (2009), essa parte da análise informal (junto com a anterior) corresponde à $4^{\mathrm{a}}$. Etapa da análise da Inferência Formal.

\section{- Conclusão}

Finalizar uma análise dos dados geralmente consiste na interpretação dos resultados obtidos por meio de gráficos, das medidas descritivas, na utilização de informações sobre o contexto no qual os dados estão inseridos e também nos conhecimentos que cada aluno carrega.

Mesmo não utilizando respaldo teórico formal, a análise informal exige justificativas e coerência quanto às afirmações e alegações feitas. É necessária uma articulação adequada das ideias e conceitos apresentados juntamente com os dados para que haja credibilidade em relação às conclusões feitas.

Pfannkuch e Horton (2009) consideram que as conclusões dos alunos precisam conter alguns elementos indispensáveis. Elas devem incorporar uma explanação que contenha os elementos percebidos por meio dos recursos utilizados na análise, numéricos e não numéricos. Precisam também considerar a questão inicial e investigativa além de um elemento que varia sempre, o conhecimento individual do aluno sobre o assunto.

Assim, recorrendo à questão investigativa, podemos concluir que os alunos do primeiro ano do período diurno apresentam notas finais ligeiramente superiores às notas finais verificadas entre os alunos do período noturno da mesma escola.

Considerando a questão inicial, podemos estender um pouco mais essa conclusão, mesmo que informalmente. Assim, diante das evidências fornecidas pelas amostras e das suposições feitas sobre as dificuldades e limitações para se quantificar o rendimento dos alunos, é plausível supor que o desempenho dos alunos do período diurno seja ligeiramente melhor do que o desempenho dos alunos do período noturno.

Também é plausível supor que isso pode ocorrer da mesma maneira em outras classes de outras escolas pois não existe, nesse caso, algum fato ou evidência que aponte necessariamente uma carac- 
terística dessas classes que as façam diferentes das demais possíveis classes, tanto do diurno como do noturno, de escolas básicas da cidade.

É importante considerar que, apesar de existir diferenças entre os valores dos dados, dentro da Inferência Informal não é possível saber se essa diferença numérica é suficiente para se concluir sobre a superioridade das notas de um período em relação ao outro, quantificando o risco associado à decisão. Essa prerrogativa é encontrada somente por meio de uma análise formal.

Pfannkuch e Horton (2009) destacam que se um padrão percebido em uma amostra aparece novamente quando se coleta outra amostra, e repetidamente a cada amostra coletada, pode-se concluir que esse padrão é reflexo de uma característica populacional, ou seja, é realmente um padrão e não algo restrito à amostra coletada, pois dificilmente isso aconteceria ao acaso.

Em termos mais realistas do que as simplificações feitas nesta análise, para essa conclusão ser estendida para além de uma escola, como por exemplo, uma cidade ou região, é necessário que as amostras contenham elementos mais diversificados provenientes de um conjunto maior.

Pfannkuch e Horton (2009) acrescentam que, ao elaborar uma conclusão, é necessário buscar algo que a justifique, algo que seja externo aos dados, mas isso nem sempre é possível, pois depende da experiência de cada um. Nesse exemplo, algo que justificaria maiores notas no período diurno seria o fato de que nesse período existem mais aulas do que no período noturno. Outra possibilidade é o fato de que, segundo os relatos de professores colegas de trabalho, os alunos do período noturno em geral trabalham e chegam cansados na escola, fato que contribui para um desempenho inferior ao desempenho dos alunos do período diurno, que em geral não chegam cansados devido ao trabalho.

Assim, para a pergunta colocada "As notas finais em Matemática dos alunos do período diurno são diferentes das notas finais em Matemática dos alunos do período noturno?", respondemos, baseados na Inferência Informal, que as análises feitas sugerem que sim, são diferentes, com uma indicação de superioridade para as notas do diurno. Na Inferência Formal, descrita na seção anterior, concluímos pela rejeição de $H_{0}$, o que indicava que as notas poderiam ser consideradas como diferentes (com certa margem de erro).

Observe que na análise formal, uma vez que a hipótese alternativa foi estabelecida como diferente, não há respaldo teórico para essa "informalidade" de sugerir a superioridade do diurno, atrelando margem de erro. Com novas evidências, o experimento poderia ser refeito, novos dados coletados, e uma análise formal teria uma hipótese alternativa unicaudal.

O que de algum modo procuramos mostrar foi que elaborar uma análise de inferência informal pode evitar que alunos se sintam oprimidos por um arcabouço teórico que não faz sentido a eles nos primeiros contatos com raciocínio inferencial. Acreditamos ser essa uma oportunidade inicial interessante, que favorece a reflexão e mostra os caminhos para uma futura análise formal, a ser feita com mais propriedade. O raciocínio estatístico que envolve incerteza e aleatoriedade pode ser apresentado já nesses passos iniciais.

\subsection{Ainda sobre Inferência Informal}

Resumindo, a Inferência Informal é um meio para atender as necessidades de análise exploratória de dados de alunos do ensino básico distantes das habilidades técnicas exigidas pelo rigor dos procedimentos formais, seja pela idade ou pela falta de pré-requisitos. Para contornar as dificuldades dos métodos formais, as abordagens informais se mostram mais intuitivas quanto às justificativas que 
sustentam afirmações. De acordo com Paparistodemou e Meletiou-Mavrotheris (2008), isso ocorre porque as ideias e técnicas exigidas pelos métodos formais estão distantes da maioria dos alunos iniciantes, seja pela idade ou pelo recente contato destes com a matéria

Embora não haja uma definição explícita e unânime do que é realmente Inferência Informal existem algumas ideias em comum presentes em publicações e trabalhos de diversos autores envolvidos com o tema, entre as quais destacamos:

- Abordagens das relações, diferenças e semelhanças existentes entre características individuais de um elemento amostral e características da amostra, bem como possíveis propriedades gerais, associadas a uma população de interesse;

- Variabilidade, suas causas e consequências (variabilidade natural da amostra, variabilidade proveniente de erros de medidas, variabilidade gerada por múltiplas causas);

- Efeitos do Tamanho da amostra e acurácia nas medidas (variabilidade em amostras grandes e variabilidade em amostras pequenas);

- Controle do viés, estímulo da investigação estatística (técnicas de seleção de amostras - aleatoriedade);

- Tendências e Padrões - estudo de características particulares e/ou individuais e do que pode ser concluído sobre a amostra e, até certo ponto, estendido à população.

Outro aspecto discutido em trabalhos relacionados à Inferência Informal é a participação ativa dos alunos. Uma postura mais construtivista visa atender às necessidades dos alunos de hoje e suprir as falhas dos métodos tradicionais no ensino da Estatística. É recomendado que os alunos deixem a tradicional posição de ouvinte e passem a participar ativamente das aulas de Estatística para que construam os significados e os relacionem com os conceitos, de acordo com as necessidades escolares, seu interesse pessoal e seu conhecimento prévio. Assim, a escola deveria caracterizar-se mais como uma oficina de produção e articulação de ideias do que como uma distribuidora de conteúdos. Naturalmente, ao longo de todas as ações docentes, os conteúdos básicos entrelaçam-se continuamente. Pode-se pensar em uma nova cultura estatística, alimentada pela interação aluno e professor. 


\section{Capítulo 7}

\section{Considerações Finais}

Uma das principais intenções educacionais é a busca por um aluno reflexivo e crítico que possa exercer sua cidadania. $\mathrm{Na}$ formação de um aluno com essas características o principal agente é o professor. É necessário que ele promova, entre outras coisas, o debate de ideias e a socialização dos conhecimentos buscando tornar o aluno cada vez mais entendido sobre o mundo ao qual pertence, relacionando os diversos tipos de informação para construir significados.

Em alguns momentos, durante os processos reflexivos, é necessário interpretar dados estatísticos. Isso acontece também para compreensão de alguns fenômenos sociais, cujo conhecimento possibilita um exercício mais consciente e crítico de cidadania. De acordo com Batanero (2001), uma das finalidades da Educação Estatística é constituir parte da educação desejável para futuros cidadãos adultos. Ben Zvi e Garfield (2004) afirmam que a Literacia Estatística é parte integrante de pessoas escolarizadas, e cada vez mais os professores precisam se preparar para ajudar os alunos a aprender e pensar estatisticamente, mostrando a cada um a utilidade prática da Estatística e sua importância para compreender o mundo do qual fazem parte.

Neste trabalho procurou-se discutir aspectos ligados à necessidade atual de desenvolver a Educação Estatística no âmbito da escola básica explorando, particularmente, uma possível abordagem para uma análise inferencial. Esta última análise foi elaborada por meio de um problema de comparação de dois grupos quanto ao desempenho escolar, cuja resolução foi apresentada tanto no âmbito da Inferência Formal quanto no da Inferência Informal, numa perspectiva de analisar dificuldades e facilidades relacionadas a estas abordagens. Isto também pode ser usado por professores das disciplinas introdutórias de Estatística em cursos de nível superior.

Explorar a Estatística, em alguns casos driblando as dificuldades matemáticas, tem sido um desafio para alunos, professores, instituições de ensino e organizações de pesquisa. O foco em técnicas e cálculos muitas vezes substitui as possibilidades de compreensão e discussão dos conceitos básicos, dificultando a preparação de futuros cidadãos. Por isso, desenvolvemos um capítulo (A Estatística e alguns conceitos) com uma análise exploratória de dados a fim de proporcionar ao professor uma leitura afinada com os conceitos fundamentais de Estatística, que acreditamos facilitar a leitura do material posterior relacionado à inferência. Enfatizamos a importância de os alunos começarem a ter contato com a análise exploratória de dados simples e elementar, acatando a sugestão de Watkins et al. (2001) de que o estudo da probabilidade não precede necessariamente o da Estatística.

A Educação Estatística tem seu desenvolvimento facilitado em um ambiente interdisciplinar e no ambiente escolar deveria encontrar um terreno fértil para seu desenvolvimento. O objetivo é encontrar um problema para além da disciplina, que possa, além de desenvolver os conceitos estatísticos, 
se tornar um centro de interesse e que seja motivador, pois os alunos tendem a se interessar mais por dados que estejam ligados a assuntos nos quais se sintam envolvidos. Considerar a realidade dos alunos e incorporá-la no estudo dos conceitos estatísticos pode possibilitar o entendimento do aluno sobre o mundo em que ele vive, podendo tornar-se um agente de mudança social à medida que aumenta sua compreensão e exercício da cidadania.

Esses componentes ligados à Educação Estatística foram apresentados no Capítulo 3, que enfatiza que o trabalho docente envolve a reflexão sobre a disciplina e um contínuo aperfeiçoamento e seleção dos meios de ensino. Cada vez mais as disciplinas se misturam e se completam fazendo com que o professor busque as soluções de diversas questões educacionais. Ben Zvi e Garfield (2004) fazem algumas recomendações que contribuem para mudança no cenário da Educação Estatística, entre elas:

- preferência por dados reais pertencentes à realidade imediata dos alunos em vez de utilizar dados pertencentes a contextos distantes dos vivenciados por eles;

- foco no desenvolvimento do letramento, raciocínio e pensamento estatísticos;

- utilizar ferramentas tecnológicas sempre que possível;

- incentivar atitudes positivas e ressaltar a força dos processos estatísticos;

- buscar vários métodos, alternativas de leitura e atividades.

Podemos notar que autores como Ben Zvi e Garfield (2004) sugerem uma abordagem sócio interativa na Educação Estatística em particular na Inferência Informal.

De acordo com Moore (2001), um apoio também importante à Inferência Informal é a possibilidade do uso de recursos tecnológicos. Com o recurso adequado é possível mostrar de várias perspectivas o que antes era somente imaginado, ouvir facilmente o que antes era raro, calcular quase imediatamente o que jamais foi feito em papel, fazer e refazer quantas vezes forem necessárias, por meio do uso de simulações. Isso acelera a compreensão e o entendimento de um assunto. Assim, o tempo para assimilação de conteúdos pode ser reduzido.

Acreditamos que a análise exploratória de dados via Inferência Informal seja o melhor caminho para desenvolver a Literacia Estatística, favorecendo o desenvolvimento e a compreensão dos conceitos fundamentais de variabilidade e incerteza que permeiam uma análise exploratória de dados. O ambiente escolar fica mais leve e o aluno será naturalmente encaminhado para as análises mais formais, que inclusive nem se esgotam numa abordagem de teste de hipóteses.

Ouvir o que devemos fazer é diferente de descobrir, pessoalmente, o que devemos fazer, transformando a descoberta em um acontecimento motivador para muitos alunos. Nesse sentido, espera-se que a aprendizagem de cada aluno seja um processo ativo e único de construção do próprio conhecimento a partir das experiências pessoais que formaram os princípios adotados na composição do conhecimento.

A adaptação e readaptação do conhecimento à medida que se vivem diversas experiências constituem um processo natural para muitos alunos na construção dos significados. A aprendizagem está sujeita a mudanças geradas pelas experiências e tende a se adaptar e se integrar à rede conceitual disponível na memória.

Este trabalho pretendeu apresentar ao professor uma alternativa para o início de análise inferencial, mostrando a correspondência entre as etapas de uma análise de Inferência Formal e aquelas 
de uma análise de Inferência Informal. Será importante prosseguir e analisar os aspectos dos obstáculos definidos por Brousseau (2008) à luz da aplicação em sala de aula, com os alunos, das técnicas discutidas de Inferência Informal.

É voz corrente que a Estatística é "muito difícil de ensinar"... "muito difícil de aprender"... Esperamos ter contribuído para amenizar esse quadro.

"O interesse dos alunos é o valor maior a ser cultivado na escola, em cada ação docente." Machado (2009). 
CONSIDERAÇÕES FINAIS 


\section{Referências Bibliográficas}

Agresti e Franklin(2007) Alan Agresti e Chris Franklin. Satatistics, the Art and Science of Leanrnig from Data. Pearson Prentice Hall. Citado na pág. 51, 54

Almodova(1978) José Almodova. Introdução Geral à Estatística. Editora Estrutura. Citado na pág. 3

Batanero(2001) Carmen Batanero. Didáctica de la estadística, Dezembro 2001. URL http: //www.ugr.es/ batanero/. Último acesso em 30/4/2014. Citado na pág. 3, 6, 9, 19, 27, 30, 35, 42, 45,73

Batanero et al.(2011) Carmen Batanero, Gail Burrill e Chris Reading eds. Teaching Statistics in School Mathematics - Challenges for Teaching and Teacher Education. Springer. Citado na pág. 45, $46,48,58,59$

Ben Zvi e Garfield(2004) Dani Ben Zvi e Joan Garfield. The Challenge of Developing Statistical Literacy, Reasoning and Thinking. Kluer Academic Publishers. Citado na pág. 1, 8, 17, 18, 28, 29, $30,31,32,33,39,40,66,73,74$

Bolfarine e Bussab(2005) Heleno Bolfarine e Wilton Bussab. Elementos da Amostragem. Editora Edgard Blucher. Citado na pág. 18

Brasil(1997) Brasil. Parâmetros Curriculares Nacionais - Ensino Fundamental I. MEC. Citado na pág. $1,5,22,29,30,31,32,35,49$

Brasil(1998) Brasil. Parâmetros Curriculares Nacionais - Ensino Fundamental II. MEC. Citado na pág. 4,7

Brousseau(2008) Guy Brousseau. Introdução ao estudo da teoria das situações didáticas. Ática. Citado na pág. $7,8,28,75$

Burril e Biehler(2011) Gail Burril e Rolf Biehler. Fundamental statistical ideias in the school curriculum and trainning teachers. Em Teaching Statistics in School Mathematics-Challenges for Teaching and Teacher Education, páginas 57-69. Springer. Citado na pág. 5

Campbell(1974) Stephen K. Campbell. Flaws and Fallacies in Statistical Thinking. Prentice-Hall. Citado na pág. 3, 6, 29

Campos(2007) Celso Ribeiro Campos. A Educação Estatística: Uma Investigação Acerca dos Aspectos Relevantes à Didática da Estatística em Cursos de Graduação. Tese de Doutorado, UNESP - Rio Claro. Citado na pág. 30, 32, 33

Campos et al.(2011) Celso Ribeiro Campos, Maria Lucia Lorenzetti Wodewotzki e Otavio Roberto Jacobini. Educação Estatística - teoria e prática em ambientes de modelagem matemática. Autêntica. Citado na pág. 27, 28

Chalmer(1987) Bruce J. Chalmer. Understanding Statistics. Marcel Dekker. Citado na pág. 3, 4, 5 
Cobb e Moore(1997) George W. Cobb e David S. Moore. Mathematics, statistics, and teaching. Mathematical Association of America, 104(9):801-823. URL http://www.stat.ucla.edu/ Rakhee/ attachments/moorecobb.pdf. Último acesso em 19/8/2014. Citado na pág. 40

Cordani(2001) Lisbeth Kaiserlian Cordani. O Ensino da Estatistica na Universidade e a Controvérsia sobre os Fundamentos da Inferência. Tese de Doutorado, IME USP. Citado na pág. 43

Cordani(2012) Lisbeth Kaiserlian Cordani. Estatística para todos - Atividades para sala de aula. IME USP - CAEM. Citado na pág. 18

delMas(2002) Robert delMas. Statistical literacy, reasoning, and learning: A commentary. Journal of Statistical Education, 10(3):1-10. URL http://www.amstat.org/publications/jse/v10n3/ delmas_discussion.html. Último acesso em 19/8/2014. Citado na pág. 32, 33

Ferreira(2000) Aurélio Buarque Holanda Ferreira. Mini Dicionário Aurélio Século XXI. Editora Nova Fronteira. Citado na pág. 5

Fiorentini e Lorenzato(2006) Dario Fiorentini e Sergio Lorenzato. Investigação em Educação Matemática. Autores Associados. Citado na pág. 2, 27

Fiorentini e Nacarato(2005) Dario Fiorentini e Adair Mendes Nacarato. Cultura, formação e desenvolvimento profissional de professores que ensinam Matemática. Editora Musa. Citado na pág. 35

Franklin et al.(2005) Christine Franklin, Gary Kader, Denise Mewborn e Jerry Moreno. Guidelines for Assessment and Instruction in Statistics Education - GAISE report. http://www.amstat.org/ education/gaise/, 2005. Último acesso em 30/4/2014. Citado na pág. 19, 46

Gal et al.(1989) Iddo Gal, Karen Rothschild e Daniel A. Wagner. Which group is better? the development of statistical reasoning in elementary school children. Em Paper presented at the meeting of Research in Child Development - Kansas City, páginas 01-09. Citado na pág. 32, 49

Garfield(2002) Joan Garfield. The challenge of developing statistical reasoning. Journal of Statistical Education, 10(3):53-67. URL http://www.amstat.org/publications/jse/v10n3/garfield.html. último acesso em 19/8/2014. Citado na pág. 32

Godino(2005) Juan D. Godino. Mathematical concepts, their meanings, and understanding, 2005. URL http://www.ugr.es/ jgodino/articulos_ingles/meaning_understanding.pdf. Último acesso em $29 / 04 / 2015$. Citado na pág. 48

Hand(2008) David J. Hand. Statistics - A Very Short Introduction. Oxford. Citado na pág. 3, 8, 9

Harradine et al.(2011) Anthony Harradine, Carmen Batanero e Allan Rossman. Students and teachers' knowledge of sampling and inference. Em Teaching Statistics in School Mathematics Challenges for Teaching and Teacher Education; páginas 235-246. 1 edição. Citado na pág. 11, 32, $47,48,58$

Hogg e Tanis(2001) Robert V. Hogg e Elliot A. Tanis. Probability and statistical inference. Em Statistics for the Twenty-First Century, páginas 3-13. The Mathematical Association of America. Citado na pág. $35,36,37$

Huber(2011) Peter J. Huber. Data Analysis - What Can Be Learned from the Past 50 Years. Wilwy. Citado na pág. 50

Konold e Pollatsek(2002) Clifford Konold e Alexander Pollatsek. Data analysis as the scarch for signals in noisy processes. Journal for Research in Mathematics Education, 33(4):259-289. URL http://www.jstor.org/discover. Último acesso em 30/4/2014. Citado na pág. 13, 24 
Lingyuan et al.(2004) Gu Lingyuan, Huang Rongjin e Marton Ference. Teaching with variation: A chinese way of promoting effective mathematcs learning. Em World Scientific Publishing Co. Pte. Ltd., editor, How Chinese Learn Mathematics, páginas 309-347. 1 edição. Citado na pág. 40, 59

Machado(2009) Nílson José Machado. Educação Microensaios em Mil Toques, volume 1. Escrituras. Citado na pág. $6,19,25,75$

Machado(2010) Nílson José Machado. Educação Microensaios em Mil Toques, volume 2. Escrituras. Citado na pág. 36

Machado(2013) Nílson José Machado. Ideias fundamentais da matemática: O par causalidade/aleatoriedade, 2013. URL http://www.nilsonjosemachado.net/SEMA20130315.pdf. Último acesso em 30/08/2014. Citado na pág. 28

Magalhães e Lima(2011) Marcos Nascimento Magalhães e Antonio Carlos Pedroso de Lima. Noções de Probabilidade e Estatística. Edusp. Citado na pág. 3, 4, 9, 13, 23, 25, 39, 46, 53, 54, 56, 57,64

Makar e Rubin(2009) Katie Makar e Andee Rubin. A framework for thinking about informal statistical inference. Statistics Education Research Journal, 8(1):82-105. URL http://www.stat. aukland.ac.nz/serj. Último acesso em 30/4/2014. Citado na pág. 41

Melo(2005) Gilberto Francisco Alves Melo. Saberes docentes de professores de matemática em um contexto de inovação curricular. Em Editora Musa, editor, Teaching Statistics in School Mathematics Challenges for Teaching and Teacher Education. Editora Musa, 1 edição. Citado na pág. 36

Moore(2000) David Moore. A Estatística Básica e sua Prática. Livros Técnicos e Científicos. Citado na pág. $3,4,5,6,10,11,14,16,21,22,23,28,29,30,39,40,45,46$

Moore(2001) David S. Moore. Teaching statistics as a respectable subject. Em Statistics for the Twenty-First Century, páginas 15-25. The Mathematcial Association of America. Citado na pág. 37,74

Paparistodemou e Meletiou-Mavrotheris(2008) Efi Paparistodemou e Maria MeletiouMavrotheris. Developing students' Informal Inference skills in data analysis. SERJ - Statistics Educational Research Journal, 7:83-106. Citado na pág. 71

Pfannkuch(2006) Maxine Pfannkuch. Comparing box plot distributions: A teacher's reasoning. Statistics Education Research Journal, 5(2):27-45. URL http://www.stat.aukland.ac.nz/serj. Ültimo acesso em 30/4/2014. Citado na pág. $6,8,13,22,24,25,35,41,49,51$

Pfannkuch e Horton(2009) Maxine Pfannkuch e Nicholas Horton. A teacher's guide to informal comparative reasoning, 2009. URL http://new.censusatschool.org.nz/wp-content/uploads/2009/ 07/nzteachersguide-2009-08-04.pdf. Último acesso em 30/4/2014. Citado na pág. 22, 23, 50, 60, 61, $62,63,64,66,69,70$

Pfannkuch et al.(2010) Maxine Pfannkuch, Matt Regan e Chris Wild. Telling data stories: Essential dialogues for comparative reasoning. Journal of Statistics Education, 18(1):1-38. URL http://www.amstat.org/publications/jse/v18n1/pfannkuch.pdf. Último acesso em 30/4/2014. Citado na pág. 59

Reading e Shaughnessy(2004) Chris Reading e J. Michael Shaughnessy. Reasoning about variation. Em The Challenge of Developing Statistical Literacy, Reasoning and Thinking, páginas 201-22669. Kluwer Academic Publishers. Citado na pág. 12, 17

Rees(1995) D. G. Rees. Essential Statistics. Chapman Hall. Citado na pág. 3, 37 
Rubin e Hammerman(2006) Andee Rubin e James K. L. Hammerman. Exploring informal inference with interactive software. Em ICOTS-7, páginas 01-06. Citado na pág. 41

São Paulo(2011) Governo do Estado de São Paulo. Currículo do Estado de São Paulo - Matemática e suas Tecnologias, 2011. URL http://www.educacao.sp.gov.br/a2sitebox/arquivos/ documentos/238.pdfl. Último acesso em 30/4/2014. Citado na pág. 3

Severino(2007) Antônio Joaquim Severino. Metodologia do Trabalho Científico. Editora Cortez. Citado na pág. 5, 27, 31, 32

Sotos et al.(2007) Ana Elisa Castro Sotos, Stijin Vanhoof, Win Van den Noortgate e Patrick Onghena. Students' misconceptions of statistical inference: A review of the empirical evidence from research on statistics education. Eductional Research Review, 2:98-113. Citado na pág. 8, 11, $12,29,46$

Spiegel(2006) Murrey R. Spiegel. Estatística. Pearson Makron Books. Citado na pág. 3, 4

Watkins et al.(2001) Ann Watkins, Gail Burril, James M. Landwehr e Richard L. Scheaffer. Remedial statistics? the implications for colleges of the changing secondary school curriculum. Em Statistics for the Twenty-First Century, páginas 45-55. The Mathematcial Association of America. Gitado na pág. 25, 73

Watson e Moritz(1999) Jane M. Watson e Jonathan B. Moritz. The beginning of statistical inference comparing two data sets. Educational Studies in Mathematics, 37(2):145-168. URL http://www.jstor.org/stable/3483313. Último acesso em 30/4/2014. Citado na pág. 49, 59

Wild et al.(2011) Chris J Wild, Maxine Pfannkuch, Matt Regan e Nicholas Horton. Towards more accessible conceptions of statistical inference. The Royal Statistical Society, 174(2):247-295. URL http://onlinelibrary.wiley.com/doi/10.1111/j.1467-985X.2010.00678.x/full. Último acesso em 19/10/2014. Citado na pág. 40

Zieffler et al.(2008) Andrew Zieffler, Joan Garfield, Robert Del Mas e Chris Reading. A framework to support research on informal inferential reasoning. Statistics Education Research Journal, 7(2): 40-58. URL http://www.stat.aukland.ac.nz/serj. Último acesso em 30/4/2014. Citado na pág. 41, 42,49 